\title{
What should be done about rising unemployment in the UK?
}

David N.F. Bell

David G. Blanchflower

Stirling Economics Discussion Paper 2009-06

February 2009

Online at http://www.economics.stir.ac.uk 
David N.F. Bell is Professor of Economics at the University of Stirling and Budget Adviser to the Finance Committee of the Scottish Parliament

David G. Blanchflower is Bruce V. Rauner Professor, Economics Department, Dartmouth College, part-time Professor in the Division of Economics, Stirling Management School, University of Stirling, Director of the "Future of Labor" programme at IZA, Bonn. He is a member of CESifo and NBER. He is also a member of the Monetary Policy Committee, Bank of England

\section{Acknowledgements}

We thank Alex Bryson, Andrew Clark, Peter Elias, Paul Gregg, Geraint Johnes, Conall Mac Coille, Robert MacCulloch, Steve Machin, John Martin, Andrew Oswald, Philip Oreopoulos and Alois Stutzer for helpful comments and suggestions. 


\section{Summary}

This paper considers the issue of unemployment one of the most pressing issues facing the UK and other governments, as the current recessions deepens. It begins by trying to accurately date the beginning of the current downturn in the British economy, arguing that it is clear that the recession commenced in the $2^{\text {nd }}$ quarter of 2008 . It then examines whether this recession is substantively different from past downturns in the UK and argues that, although the extreme rationing up of credit marks the current recession as different, some of the labour market consequences, such as the concentration of unemployment among the young and other disadvantaged groups, is typical of past experience.

The paper reviews past literature on the causes of unemployment, arguing that the origin of the present difficulties lies with a collapse in demand rather than with frictions in the labour market caused by institutional inflexibilities. There is a large literature on the negative impact of unemployment both on society and on individuals. The adverse societal consequences are reviewed in the next section, while we discuss some of our own research on the adverse consequences on the individual in Section 6.

Just as in previous recessions, it is becoming clear that some groups will suffer a much higher incidence of unemployment during this downturn and therefore suffer to a greater than average extent the adverse individual effects that we discussed in Section 6. The evidence on the composition of these groups is reviewed and presented along with some of our own research on this issue in the following section.

One of the key groups who are likely to be affected by the recession is the young. In Section 8 , we review the particular difficulties faced by them in trying to secure a footing in the labour market. In the last two decades many governments have introduced policies (collectively described as Active Labour Market Policies or ALMPs) for direct intervention in the labour market to improve outcomes for particular groups and for the young in particular. The next section reviews the evidence on the success of these policies. The final section discusses some policy proposals which we offer to alleviate what we believe will be the very serious adverse consequences of the likely increase in unemployment in the UK over the short to medium 
"You take my life when you do take the means whereby I live"

The Merchant of Venice, Act IV, William Shakespeare.

\section{Introduction}

The UK, the Euro area and the European Union as a whole all entered 2009 in recession. There is a possibility that this recession will be the deepest and longest lasting since the Great Depression. We expect negative growth to continue in the UK for several more quarters at least, although how long it does so will depend on the effectiveness of the various fiscal and monetary stimuli, including 400 basis points of cuts in interest rates that have been undertaken recently.

For most of the time since the turn of the millennium the UK labour market had performed very well on a variety of measures, including employment growth and unemployment. Between January 2000 and April 2008 employment grew by nearly two million from $27,310,000$ to $29,541,000$. Over the same period the employment to population rate (EPOP) grew from $59.3 \%$ to $69.3 \%$. The level of unemployment was little changed although the unemployment rate fell from $5.8 \%$ to $5.2 \%$ as the labour force increased. It wasn't all good news, because youth unemployment, particularly of 18-24 year olds, increased from $12.7 \%$ in 2000 to $14.5 \%$ in 2008 , whereas the youth rate declined across the rest of the OECD. This should all be placed in context though. Before the onset of recession, at the start of 2008, Appendix A shows that unemployment in the UK at 5.1\% was still higher than in Austria (4.0\%); Denmark (3.2\%); Ireland (4.9\%); Japan (3.9\%); Netherlands (2.8\%); Norway (2.5\%) and USA (4.9\%).

The UK labour market performed well on these indicators in comparison to most other EU and OECD countries. Indeed, Pissarides (2006) described the recent performance of the UK labour market as a "European success story". ${ }^{1}$ Figure 1 plots the unemployment rates for ten countries (Australia, Canada, France, Germany, Italy, Japan, the Netherlands, Sweden, the UK and the USA) for the period 1960-2007. ${ }^{2}$ It is apparent from these data that:

a) pre-1980 the UK had lower unemployment rates than the US. This pattern reversed between 1980 and 2000. The reasons for this switch still remain unclear.

b) UK unemployment rates track closely those in Australia and Canada.

c) UK rates have generally been higher than those in Japan, Sweden and the Netherlands. Since 2002 rates in Sweden have been higher.

\footnotetext{
${ }^{1}$ C. Pissarides (2006), 'Unemployment in Britain: a European success story', in Structural Unemployment in Western Europe, edited by M. Werding, CESifo Seminar Series, MIT Press, Cambridge, MA.

2 The data are provided by the Bureau of Labor Statistics in the US, approximating U.S. concepts. $\mathrm{ftp}: / / \mathrm{ftp}$. bls.gov/pub/special.requests/ForeignLabor/lfcompendiumt02.txt
} 
d) Since the early 1990s UK unemployment rates have been below those in France, Germany and Italy whereas the UK had generally higher rates before then.

The situation in the UK labour market has worsened markedly since April 2008 on every measure. Unemployment increased by 300,000 between April and November 2008 and from $5.2 \%$ to $6.1 \%$. The outlook for the UK labour market is grim.

Labour markets have also loosened sharply over the last year in a number of other countries since the start of 2008, especially in Ireland ( +3.4 percentage points), Spain $(+4.1 \mathrm{pp})$, Sweden $(+1.2 \mathrm{pp})$ and the United States $(+1.5 \mathrm{pp})$, with the numbers in parentheses the percentage point increase in the unemployment rate between December 2007 and the latest available data for October or November 2008. The joblessness crisis which the UK faces is being replicated across many of the world's industrialized countries.

This paper fills in some of the detail behind this stark picture of the current UK recession. The paper compares this recession with other recent downturns, noting the similarities and differences that have emerged thus far. It then focuses on unemployment, considering why we should be concerned about this issue, what we know from recent experience about the characteristics of the unemployed and what we know about the well-being of the unemployed. We specifically consider the causes and consequences of rising youth unemployment. The penultimate section examines the experience of labour-market measures designed to reduce the burden of unemployment and summarizes what is known about their effectiveness. The final section considers what measures should be taken to combat the rise in unemployment.

\section{Dating the Recession}

The NBER dating committee dated the start of the recession in the United States to December 2007 when non-farm payrolls started to fall. ${ }^{3}$ Using the same method it appears that the start of the recession in the UK was April 2008. This is illustrated in Table 1, which reports employment data and monthly changes for both the UK and the US. Redundancies also started to rise and vacancies started falling during 2008. Redundancies were approximately 100,000 higher in the quarter Sep-Nov 2008 compared with the quarter March-May 2008. ${ }^{4}$ Vacancies were approximately 150,000 lower in December compared with April 2008. Youth unemployment also increased sharply (Figure 2).

Over the past decade or so a disproportionate part of the growth in the number of jobs was in self-employment. Between 2001 and 2006, the number of employees increased by $3.5 \%$, while the number of self-employed workers increased by $13.7 \%$. Along with other indicators self-employment also started to decline from its high point in April 2008

\footnotetext{
${ }^{3}$ http://www.nber.org/cycles/dec2008.html

${ }^{4}$ Labour Market Statistics, First Release, ONS, January 2009.
} 
(Figure 3). Between the three month period December 2007-February 2008 and the three month period September-November 2008, the numbers of employees fell by 30,000 compared with a decline of 42,000 in the number of self-employed, even though, at the end of 2008 the self-employed only account for $13 \%$ of workers. This decline is unsurprising given the earlier finding that as much as a half of the prior growth in selfemployment was driven by house prices, which freed up capital constraints, which are known to be especially important for the self-employed. ${ }^{5}$ The onset of the credit crunch and the consequent decline in house prices was predictably going to hit the self-employed especially hard, and so it has turned out.

Appendix Table A1 presents evidence on standardized unemployment rates in Europe, the United States and Japan from 1996-2007. A number of facts stand out from the tables. First, unemployment in the UK started to increase from 2005. Apart from Ireland and Portugal, unemployment rates fell elsewhere over this period. Appendix Table A2 presents the most up to date information on unemployment rates from December 2007 to October 2008, with three observations for November. It is clear from the table that the UK was not alone in seeing a significant turn around in its labour market in the spring of 2008. Unemployment appears to have started to increase in both the EU and the Euro area from March 2008. The Euro area, including France, Italy, Portugal and Sweden, experienced increased unemployment in Spring 2008, coincident with the most recent upturn in the UK. If one looks at employment growth, this also turned negative in both the EU and the Euro area in 2008 Q2, confirming that this was the date of the start of the recession using the NBER definition.

Table 2 presents evidence on GDP growth rates. It is apparent that, despite the fact that the NBER Dating Committee called the US recession as having started in 2007 Q4, at the time of writing (January 2009), the US has still not had two consecutive quarters of negative GDP growth. Interestingly, though, since 2007 Q4 the Euro area has, as have Denmark, Germany, Estonia, Iceland, Ireland, Italy, Latvia, Sweden and Japan. The UK has now had one quarter of zero growth, which in our view, will likely subsequently be revised down to negative growth, followed by two successive quarters of negative growth. The Q42008 estimate was 1.5\%, the worst since Q2 of 1980. It is apparent that there is widespread slowing in the rest of the EU. In 2008 Q3, out of the twenty-nine countries for whom there are estimates, fourteen had negative growth in that quarter. With the exception of Ireland, France, Slovenia and the Netherlands, which have each experienced two quarters of zero growth, output in 2008 Q3 was lower than in the second quarter. There is evidence of slowing in other parts of the world, including China and India. The world economy is slowing fast.

Table 3 presents evidence on the duration of unemployment in the UK. Data are available on both ILO unemployment and the claimant count. It is also apparent from the

\footnotetext{
${ }^{5}$ On the importance of capital constraints for the self-employed see D.G. Blanchflower and A.J. Oswald (1998), 'What makes an entrepreneur?' Journal of Labor Economics, January, 16(1), pp. 26-60. On the role house prices in stimulating self-employment see D.G. Blanchflower and C. Shadforth (2007), 'Entrepreneurship in the UK', Foundations and Trends in Entrepreneurship, Vol. 3, No. 4, pp. 257-364.
} 
claimant count that unemployment started to rise, quite sharply, from April 2008. It is also apparent that the numbers of those unemployed for less than six months is the category that is increasing fastest. By the spring and summer of 2008 there had been relatively few redundancies. It appears that firms had stopped hiring and this especially impacted new entrants, hence the rapid increase in youth unemployment. To this point long-term unemployment is not a major problem: that is likely to change as the recession proceeds.

Redundancies are starting to hit rapidly - in the financial sector and elsewhere. The downturn is affecting senior executives as well as shop-floor workers: last year, the 2008 National Management Salary Survey revealed that the redundancy rate among senior management teams in the UK had reached 3 per cent. Its value had more than doubled over the previous 12 months.

A number of other data series have also shown the dramatic slowing of the UK economy. The fear of unemployment increased sharply in 2008 in both the EU and especially in the UK (Figure 4). ${ }^{6}$ Here the fear of unemployment is the survey balance of people of respondent's views on what they expect to happen to unemployment over the following 12 months. That series started its inexorable rise from July $2007 .^{7}$ The rise in this series is especially evident from August 2008. In the first two columns of Table 4 we present the average survey balance for consumers by country since 1985 and the values for January. ${ }^{8}$ It is apparent that the fear of unemployment has risen rapidly across the EU since August 2008. It is above its survey average in every country. The fear of unemployment is high and rising, even in countries such as Austria, Denmark and the Netherlands, which have relatively low unemployment rates.

${ }^{6}$ For more on the fear of unemployment see D.G. Blanchflower and C. Shadforth (2009), 'Fear, Unemployment and Migration', forthcoming in the Economic Journal and D.G. Blanchflower and H. Lawton, 'The impact of the recent expansion of the EU on the UK labour market', forthcoming in EU Enlargement and the Labor Markets, edited by Martin Kahanec and Klaus F. Zimmermann, IZA and Praeger.

${ }^{7}$ The data are downloadable from http://ec.europa.eu/economy finance/db indicators/surveys9185 en.htm The questions are as follows. a) Consumers - Q7 How do you expect the number of people unemployed in this country to change over the next 12 months? The number will. increase sharply, increase slightly, remain the same, fall slightly, fall sharply, don't know. The consumer balance is calculated as $[(\%$ increase sharply $)$ - $(.5 *$ increase slightly $]$ - [ $(\%$ decrease sharply $)$ - $(.5 *$ decrease slightly $]$. b) Firms - Q7 How do you expect your firm's total employment to change over the next 3 months? It will increase remain unchanged or decrease. The industry balance is just \%increase-\%decrease.

8 The data are available for Belgium, Denmark, Germany, Ireland, Greece, France, Italy, Netherlands, the UK since 1985; Portugal and Spain since 1986 Finland since 1987 Hungary and Latvia since 1993; Austria and Sweden since 1995; Slovenia since 1996; Slovakia since 1999; Poland, Romania, Cyprus and Lithuania since 2001; Luxembourg and Malta since 2002 
In the remaining columns of Table 4 we also present the employment intentions balances of firms in four sectors - manufacturing, services, retailing and construction. Negative balance means the firms expect employment to decrease over the next three months. We present the survey averages from 1985 and the January 2009 level. The data are entirely consistent with the fear of unemployment data from consumers. For the EU as a whole, and the Euro area and for every country, firms expect significant declines in employment across all four sectors. The proportion saying they will cut employees is much larger than the survey averages in nearly all countries and especially so in the UK and Sweden.

Table 5 reports recent time series on the fear of unemployment series in the UK, which has grown steadily above its long run average of 23 from early in 2008 . We also report recent changes in the EU firm data for the four sectors reported in Table 4 above. Each of these series deteriorated markedly from April/May 2008. A similar story also applies to employment expectations in CIPS manufacturing and services which also started falling sharply from the spring of 2008. The final part of Table 5 reports new evidence on both the current employment situation and employment expectations from individuals sampled by the Nationwide. Both indices fell from around May/June, well before the collapse of Lehmans. The very low reading for the expected availability of jobs in January 2009 is particularly notable. Only $15 \%$ of respondents in January 2009 said that there would be many/some jobs available in six months time compared with $37 \%$ in June 2008 .

The EU also publishes an overall sentiment index each month for member countries summarizing business and consumer views, based on responses from both individuals and firms. ${ }^{9}$ Figure 5 plots the series for the UK and for the EU. The series dropped off a cliff in 2008 and now stands at its lowest point since the survey began in 1985. Notably in the UK the series has now declined every month since March 2008. The highest point of the index was reached in September 2007.

Consistent with evidence of a slackening labour market reported by the ONS there has also been a rapid slowing in a number of qualitative measures relating to the labour market. These include the CIPS employment surveys for manufacturing and services (Figure 6); the REC survey of the Demand for Staff (Figure 7) and surveys of employment intentions conducted by the Bank of England's agents (Figure 8). Interestingly both the CIPS and the REC survey indicator for temporary placements, which are conducted monthly, all reached their peaks in April 2008. The REC survey balance for permanent placements reached its peak in March 2008. Both the REC and both CIPS surveys are at historic lows. The CIPS surveys in particular forecast the downturn well. They do a much better job than any of the more quantitative indicators, which are traditionally used in macro models, which in part explains why so many forecasters and commentators did not see the downturn coming, or if they did, its severity.

\footnotetext{
${ }^{9}$ The Economic Sentiment Indicator is a composite measure (average $=100$ ) published by the EU monthly for each member country. http://ec.europa.eu/economy_finance/db_indicators/db_indicators 8650 en.htm
} 
The BCC is conducted quarterly and reached its peak in 2007Q4 and the survey balances for manufacturing and services are plotted in Figure 9. The balances are firm's views response to the question: 'what changes do you expect to your workforce over the next 3 months: increase/remain constant/decrease?' The balances are determined by subtracting the percentage of companies reporting decreases from the percentage of companies reporting increases.

The most recent survey for 2008Q4 which covers almost 6,000 businesses employing over 680,000 people has very recently become available. The respondents are spread throughout the United Kingdom. Businesses were surveyed by postal and online questionnaires over the period $17^{\text {th }}$ November to $10^{\text {th }}$ December 2008. An important event of note within the survey period was the Chancellor of the Exchequer's Pre-Budget Report, released on 24 November, meaning a large proportion of survey responses were given in light of the announcements. Furthermore, this is the first Quarterly Economic Survey since the collapse of Lehman Brothers and the ensuing global financial turmoil. The survey showed stark deteriorations in employment intentions in both manufacturing and services. Of particular interest is the fact that the BCC provides data by firm size and by region for both manufacturing and services: we present the data for 2008Q3 and 2008Q4 (weighted). (Source: British Chambers of Commerce Quarterly Economic Survey, Q42008).

National

$1-19$ employees

20-199 employees

200-499 employees

$500+$ employees

Scotland

North East

North West

Yorkshire \& Humberside

East Midlands

West Midlands

Wales

Eastern

South East

South West

London

Northern Ireland

\begin{tabular}{|c|c|}
\hline \multicolumn{2}{|c|}{ Manufacturing } \\
\hline Q32008 & Q42008 \\
\hline-11 & -41 \\
\hline 14 & -19 \\
\hline-8 & -29 \\
\hline-7 & -56 \\
\hline-22 & -45 \\
\hline-33 & -24 \\
\hline 29 & -66 \\
\hline-11 & -5 \\
\hline-30 & -51 \\
\hline-10 & -41 \\
\hline-12 & -43 \\
\hline-38 & -47 \\
\hline 1 & -6 \\
\hline-7 & -27 \\
\hline-5 & -58 \\
\hline 40 & -13 \\
\hline-13 & -11 \\
\hline
\end{tabular}

\begin{tabular}{cc}
\multicolumn{2}{c}{ Services } \\
Q32008 & Q42008 \\
3 & -24 \\
9 & -5 \\
-2 & -28 \\
-11 & -27 \\
15 & -41 \\
14 & -49 \\
11 & -48 \\
2 & -10 \\
-3 & -28 \\
12 & -16 \\
14 & -18 \\
-1 & -28 \\
-4 & -18 \\
-16 & -17 \\
8 & -32 \\
9 & -25 \\
-9 & -41
\end{tabular}

The BCC survey makes clear the sharp deterioration in employment expectations that occurred in the fourth quarter of 2008. This occurred in manufacturing and services in every region and was especially pronounced in larger firms.

Not only has there been a slowing of a number of qualitative measures, there has also been a marked slowing in nominal wage growth. This is illustrated below from the 
Average Earnings Index: we present the latest available, three month on three month, seasonally adjusted growth rates of earnings including bonuses. Just as we found earlier with unemployment, earnings growth appears to have peaked in April 2008 in the UK and has declined quite rapidly subsequently since then. In the private sector has slowed even more rapidly since April 2008. Wages in the public sector are less influenced by movements of the unemployment rate than are wages in the private sector. ${ }^{10}$ In November 2008 earnings growth was lower in manufacturing $(2.8 \%)$ than in services $(3.4 \%)$.

\begin{tabular}{llc|lcc} 
& UK & Private sector & & UK & Private sector \\
November 2006 & $4.2 \%$ & $4.3 \%$ & April 2008 & $4.0 \%$ & $3.9 \%$ \\
September 2007 & $4.1 \%$ & $4.4 \%$ & May 2008 & $3.9 \%$ & $3.9 \%$ \\
October 2007 & $4.0 \%$ & $4.2 \%$ & June 2008 & $3.5 \%$ & $3.6 \%$ \\
November 2007 & $4.0 \%$ & $4.2 \%$ & July 2008 & $3.5 \%$ & $3.5 \%$ \\
December 2007 & $3.8 \%$ & $3.9 \%$ & August 2008 & $3.4 \%$ & $3.4 \%$ \\
January 2008 & $3.9 \%$ & $4.1 \%$ & September 2008 & $3.3 \%$ & $3.1 \%$ \\
February 2008 & $3.7 \%$ & $3.7 \%$ & October 2008 & $3.3 \%$ & $3.2 \%$ \\
March 2008 & $4.0 \%$ & $3.9 \%$ & November 2008 & $\mathbf{3 . 1 \%}$ & $\mathbf{2 . 9 \%}$
\end{tabular}

It is even more apparent that there has been a slowing in wages in 2008 from LFS data which has the advantage that it is a random sample of wage workers. ${ }^{11}$ Below we present the earnings of workers from the LFS for the most recent five quarters. There has been little or no earnings growth in 2008, whether based on hourly or weekly earnings. Mean weekly earnings in 2008Q1 were $£ 511$ compared with $£ 513$ in 2008 Q3 while hourly earnings rose from $£ 11.41$ to $£ 11.46$.

\begin{tabular}{rccc|ccc} 
& \multicolumn{3}{c|}{ Weekly earnings } & \multicolumn{3}{c}{ Hourly earnings } \\
A11 & Public & Private & All & Public & Private \\
2007 Q3 & $£ 495$ & $£ 511$ & $£ 489$ & $£ 11.44$ & $£ 12.49$ & $£ 11.06$ \\
Q4 & $£ 498$ & $£ 514$ & $£ 493$ & $£ 11.52$ & $£ 12.47$ & $£ 11.16$ \\
2008 Q1 & $£ 511$ & $£ 533$ & $£ 504$ & $£ 11.83$ & $£ 12.95$ & $£ 11.41$ \\
Q2 & $£ 514$ & $£ 534$ & $£ 507$ & $£ 11.77$ & $£ 12.85$ & $£ 11.34$ \\
Q3 & $£ 513$ & $£ 529$ & $£ 508$ & $£ 11.87$ & $£ 12.97$ & $£ 11.46$
\end{tabular}

Source: ONS http://www.statistics.gov.uk/statbase/Product.asp?vlnk=14365

\footnotetext{
${ }^{10}$ Labour Market Statistics First Release, January 2009 Table 15 and D.G. Blanchflower and A. J. Oswald (1994), The Wage Curve, MIT Press.

11 The Average Earnings Index (AEI) presented above, and the experimental Average Weekly Earnings (AWE) are both based on the Monthly Wages and Salaries Survey is a survey of 8,500 firms who have twenty or more employees. The wages of workers, in the smallest firms have a high, negative, wageunemployment elasticity (Blanchflower and Oswald, 1994). Hence, the exclusion of workers in these small firms in the survey used to calculate both the AEI and the AWE in a period when unemployment is rising sharply, is likely to generate upward biased estimates. Both the AEI and the AWE have the disadvantage that, because they are based on an average wage at a firm they miss any variation in wages within a firm which would be picked up in the LFS.
} 
Interestingly, can be seen below, there is evidence from the LFS for the UK as a whole for full-time workers, that earnings growth was muted across the whole of the earnings distribution in both the last half of 2007 and the second quarter of 2008 . There is evidence that average wages declined between Q2 208 and Q3 2008 in the highest deciles of both the hourly and weekly earnings distributions.

Weekly Earnings

Hourly earnings

\begin{tabular}{|c|c|c|c|c|c|c|c|c|}
\hline & Lowest & Lower & Upper & Highest & Lowest & Lower & Upper & Highest \\
\hline & decile & quartile & quartile & decile & decile & quartile & quartile & decile \\
\hline 2007 Q3 & $£ 223$ & $£ 290$ & $£ 606$ & $£ 855$ & $£ 5.68$ & $£ 7.29$ & $£ 15.18$ & $£ 21.59$ \\
\hline 2007 Q4 & $£ 231$ & $£ 300$ & $£ 612$ & $£ 846$ & $£ 5.78$ & $£ 7.46$ & $£ 15.18$ & $£ 21.26$ \\
\hline 2008 Q1 & $£ 231$ & $£ 300$ & $£ 616$ & $£ 865$ & $£ 5.78$ & $£ 7.50$ & $£ 15.47$ & $£ 22.26$ \\
\hline 2008 Q2 & $£ 231$ & $£ 300$ & $£ 623$ & $£ 884$ & $£ 5.78$ & $£ 7.50$ & $£ 15.54$ & $£ 22.20$ \\
\hline 2008 Q3 & $£ 231$ & $£ 301$ & $£ 615$ & $£ 865$ & $£ 5.89$ & $£ 7.58$ & $£ 15.59$ & $£ 21.92$ \\
\hline
\end{tabular}

It is clear from the labour market data, which in previous recessions has tended to be a lagging indicator, that the UK and the Euro area had both entered recession by April of $2008 .^{12}$ Such a conclusion is also confirmed when one examines other qualitative data including consumer and business confidence and a panoply of scores reported by the Bank's agents. ${ }^{13}$ The quantitative data such as GDP, for both the Euro area and the UK, now confirms that the turning point was 2008 Q2. GDP growth was flat in 2008 Q2, which was the first quarter for 16 years there had not been positive growth. GDP fell by $0.6 \%$ in $2008 \mathrm{Q} 3$. Business investment fell in the second quarter. Growth in consumer spending has declined significantly during 2008. Spending on both services and durable goods fell in Q2. By the spring of 2008 the UK had entered recession. There were many broad similarities with what had happened a few months earlier in the United States.

There has been some suggestion that the world economy turned sharply downwards in September of 2008 after the failure of Lehman Brothers. There certainly appears to have been a widespread collapse of confidence in the banking systems of the industrialized world. However, the collapse of Lehman Brothers had little or nothing to do with falls in electricity output in China, declining car sales in Brazil, falls in Japanese or German industrial production, job losses in the US, declining manufacturing output in the UK, declining global trade or falls in the Baltic Dry. All of these declines were in train well before the collapse of Lehman Brothers. For example, the US housing market turned in January 2006, the US economy went into recession in December 2007 and the EU, the Euro area and the UK were already in recession by April 2008. Japan first experienced

\footnotetext{
${ }^{12}$ Indeed, if one looks at the claimant count that would suggest the start of the recession was even earlier in January 2008 when the count was at its low point of 794,900. In November 2008 the claimant count stood at $1,071,900$.

13 D.G. Blanchflower (2008) 'Inflation, expectations and monetary policy', Bank of England Quarterly Bulletin, pp 229-237, Volume 48 No. 2, Q2 and D.G. Blanchflower (2009), 'Where next for the UK economy?', Scottish Journal of Political Economy, forthcoming, February.
} 
negative growth in Q2 2008 (Table 2). Moreover, the Baltic Dry Index had already fallen from 11,793 on May $20^{\text {th }} 2008$ to 4,747 on September $15^{\text {th }}$, when Lehmans filed for bankruptcy. The UK house price bubble had also burst well before September 2008. For example, the Nationwide Housing Index had already fallen by $11.4 \%$ between January and August 2008, of which 7.3\% occurred between May and August of 2008 alone, while the Halifax House Price Index fell 11.2\% between January and August 2008 and by $7.9 \%$ from May to August 2008. None of this had much of anything to do with the collapse of Lehman Brothers; these events were already in train. The fact that these economies were already in a significant recession was likely the cause of Lehman's demise rather than the reverse.

\section{Comparisons with Previous Recessions}

How does this recession compare with other recent downturns? The last two recessions occurred in the early 1990s and 1980s. During these periods GDP contracted for five successive quarters, and it took over three years for output to gradually recover to its prerecession level. So if past recessions are any guide UK GDP is likely to continue contracting until at least the second half of 2009. Previous recessions have varied substantially in the severity and duration of their effects on the labour market. The unemployment rate rose for four years following the first oil shock in the early 1970s, from $3.4 \%$ to $5.7 \%$ and by $5.5 \mathrm{pp}$ between 1980 and 1982, remaining in double figures until 1987. The unemployment rate rose for 3 years in the early 1990 s rising by $3.8 \mathrm{pp}$ and only fell back to its pre-recession level by the end of 1997. So the current deterioration in labour market conditions is likely to persist for the foreseeable future. Past recessions may have led to adverse effects on the supply potential of the economy. Long-term unemployment, particularly at a young age, is damaging to future labour market prospects both for the individuals involved and the economy as a whole. Workers may lose their skills, causing a loss of human capital. High rates of unemployment may mean there is a mismatch between those skills that workers possess and those for which there is demand within the economy. People may also be less likely to participate in the labour market the longer their spell of unemployment persists. ${ }^{14}$

Thus far, we only have a relatively small amount of data, but some interesting trends have emerged. First, it is clear that the labour market is not so flexible as to absorb significant shocks to output without some adjustment to the quantity of labour demanded. Figure 10 shows the claimant count unemployment rate and the deviation of GDP from its long-run trend (measured on the right-hand vertical axis) for the period 1971 to 2008. Major turning points in the unemployment series are indicated by grey vertical lines. It shows that:

1. The unemployment rate and deviations from trend GDP are strongly negatively correlated throughout this period.

\footnotetext{
${ }^{14}$ D.G. Blanchflower (2009), 'Macroeconomic policy responses in the UK', Leverhulme Globalisation Lecture, University of Nottingham, $29^{\text {th }}$ January 2009.
} 
2. Turning points in output typically precede those in unemployment. This timing reflects firm uncertainty over downturns in demand, the desire to hoard skilled labour and increased stock building. This finding is evident from Figure 10, and can be confirmed with a standard Granger causality test. A simple VAR model with a four period lag shows that the impulse response of unemployment to changes in output is concentrated in the following three quarters. There is no significant feedback from unemployment to output. $^{15}$

Second, previous recessions have varied substantially in the severity and duration of their effects on unemployment. Measured from the turning points in unemployment the recession associated with the first oil shock began in 1973 Q4 when ILO unemployment was 3.4\%. Unemployment continued to rise until it reached $5.7 \%$ in $1977 \mathrm{Q} 4$. The "Thatcher crash" began in 1979 Q2 (5.3\%) and continued until 1984 Q2 (11.8\%), by which time the unemployment rate had been in double figures for two full years. Finally, the last recession, which followed the "Lawson boom" began in 1990 Q2 (6.9\%). The unemployment rate rose for the next 11 quarters, peaking at 10.6 per cent in 1993 Q1. The unemployment rate starts this recession (5.4\%) from a lower level than the recession of the 1990s. But if past experience does provide any pointer to the duration of the present downturn, the portents are not good. At just under three years, the 1990s recession was the shortest in recent experience. Further indication that cyclical upturns in unemployment in the UK tend to be between three and six years long comes from the Great Depression which lasted for four years between 1929 and 1932, during which time the national insurance unemployment rate rose from 10.4 per cent to 22.1 per cent.

Third, a number of economists have argued that oil spikes have significant macroeconomic effects. James Hamilton, for example, has pointed out that "nine out of ten of the US postwar recessions since WWII were preceded by a spike up in the price of oil". ${ }^{16}$ Chen et al (2008), for example, conclude that "the paper's elasticities therefore are large enough to be consistent with the belief that oil shocks play an influential role in shaping business downturns". The literature suggests that it does take considerable time for the adverse effects of an oil price shock to feed through to the real economy. One possibility is that the negative effects of the oil shock have been under-estimated and the delayed impacts will be almost as marked as in previous oil shocks. The worry then is that the rise in oil, commodity and food prices which preceded the recession may have effects on the labour market well after these price increases have themselves dissipated,

\footnotetext{
${ }^{15}$ To ensure stationarity and following the application of Dickey-Fuller and Phillips-Perron tests, the VAR system was estimated in first-differences of the unemployment rate and the deviation of output from its trend. Details available on request.

16 Hamilton, James D. (1983), 'Oil and the macroeconomy since World War II', Journal of Political Economy, 91(2), pp. 228-248. Hamilton, J. D. (2008), 'Oil and the macroeconomy', in the New Palgrave Dictionary of Economics, Second Edition. Carruth, A.A., M. A. Hooker, and A.J. Oswald (1998), 'Unemployment equilibria and input prices: theory and evidence', Review of Economics and Statistics, 80, 621-628. Chen, N, L. Graham and A.J. Oswald (2007), 'Oil prices, profits, and recessions: an inquiry using terrorism as an instrumental variable', University of Warwick DP \#809.
} 
leading to additional unemployment. Past experience suggests that the repercussions of oil shocks take years to dissipate.

The conventional description of past recessions is that the increase in unemployment has been driven by the fall in outflow rates - see e.g. Pissarides (1986), Layard, Nickell and Jackman (1991), OECD (1994), and Nickell (1999). ${ }^{17}$ Thus, as inflows exceed outflows, the stock of unemployment increases and its duration extends. Burgess and Turon (2005) argue that this literature does not properly account for the data generating process including the inter-temporal identity linking stocks and flows, which jointly determine duration. ${ }^{18}$ They argue, using a VAR model of flows, that 85 per cent of the innovations in the stock of unemployment can be explained using only inflow data. The notion that inflows play an important role in determining unemployment dynamics partly switches the policy focus towards preventing redundancies rather than providing assistance to the unemployed to find jobs.

Reinhardt and Rogoff (2009) show that financial crises have "deep and lasting effects on asset prices, output and employment". ${ }^{19}$ More often than not, they argue, the aftermath of severe financial crises share three characteristics. First, asset market collapses are deep and prolonged. Real housing price declines average 35 percent stretched out over six years, while equity price collapses average 55 percent over a downturn of about three and a half years. Second, the aftermath of banking crises is associated with large declines in output and employment. The unemployment rate rises an average of 7 percentage points over the down phase of the cycle, which lasts on average over four years. Output falls (from peak to trough) an average of over 9 percent, although the duration of the downturn, averaging roughly two years, is considerably shorter than for unemployment. Third, the real value of government debt tends to explode, rising an average of 86 percent in the major post-World War II episodes.

The concern here is that the current recession will be deeper and longer lasting than previous downturns. The extent of the monetary contraction is historically large as is the scale of the fiscal and monetary responses. We are now in a coordinated global slowdown. With an impaired monetary transmission mechanism it is hard to know how long it will take for the UK economy to recover.

\footnotetext{
${ }^{17}$ Layard, R., Nickell, S. J. and Jackman, R. (1991), Unemployment: Macroeconomic Performance and the Labour Market, OUP: Oxford. Nickell, S. J. (1999), 'Unemployment in Britain', in P. Gregg and J. Wadsworth (eds.), The State of Working Britain, MUP: Manchester. OECD (1994), The OECD Jobs Study, OECD: Paris. Pissarides, C. (1986), 'Unemployment and vacancies in Britain', Economic Policy, vol. 3, pp. 499-560.

${ }^{18}$ Burgess, S. and Turon, H. (2005), 'Unemployment dynamics in Britain', The Economic Journal, 115 (April), 423-448.

19 C.M. Reinhart and K.S. Rogoff (2009), 'The aftermath of financial crises', NBER Working Paper \#14656.
} 


\section{Causes of Unemployment}

The orthodox explanation of unemployment that argues that institutions matter ${ }^{20}$ has been subject to fairly extensive econometric testing, and in recent years, the validity of the empirical results supporting this view has been called into question. It has proved difficult to estimate a set of cross-country panel unemployment regressions that contain a lagged unemployment rate and a full set of year and country dummies and show that any of the labour market rigidity variables work. This is a crucial test. This is the first main similarity between European labour markets: labour market institutions do not tend to cause unemployment. The major exception is changes in the replacement rate, which, in some specifications, do appear to be negatively correlated with changes in the unemployment rate. Blanchard and Wolfers (2000) have argued that "the interaction of shocks and institutions does a good statistical job of fitting the evolution of unemployment both over time and across countries." This result is questionable because it is obtained in an over-fitted model - few data points and lots of variables - and the results appear to be driven by the cross-section variation rather than by any time series changes. $^{21}$ There are only eight time series data points as they use five year averages from 1960-1995.

As an illustration, we ran a pooled cross country time-series using the CEP/OECD Institutions data for 1975-2002 for eighteen OECD countries (Australia; Austria; Belgium; Canada; Denmark; Finland; France; Germany; Ireland; Italy; Japan; Netherlands; Norway; Portugal; Spain; Sweden; United Kingdom and the United States). We included controls for union density (udnet_vis), the strictness of employment protection legislation (epl), gross benefit replacement rates data (brr1) and the tax wedge $(t w){ }^{22}$ The dependent variable was the log of the unemployment rate and the equation includes a full set of country and year dummies. Coefficients and t-statistics are as follows. Only the lagged dependent variable is significant in any specification, whether the model is run without year dummies or country dummies (column 1); with year dummies (column 2) or both country and year dummies (column 3). The 'flexibility' explanation of unemployment is wrong.

(1)

Log of unemployment rate t-1 $_{1}$ Union density
$.9333(80.39)$ $-.0004(0.91)$
(2)

$.9415(70.61)$ $-.0006(1.52)$
(3) $.0011(0.89)$

20 R. Layard, S.N. Nickell and R. Jackman (2005), Unemployment, macroeconomic performance and the labour market, Oxford University Press, $2^{\text {nd }}$ edition. S.N. Nickell (2006), 'A picture of European unemployment: success and failure', in Structural unemployment in Western Europe, edited by $\mathrm{M}$. Werding, CESifo Seminar Series, MIT Press, Cambridge, MA.

${ }^{21}$ Blanchard, O., and Wolfers, J. (2000), 'The role of shocks and institutions in the rise of European unemployment: The aggregate evidence', Economic Journal, 110 (462) 1-33.

${ }^{22}$ The names in parentheses are variable names as explained in W. Nickell (2006), 'The CEP - OECD Institutions Data Set (1960-2004)', Centre for Economic Performance, LSE, September. 


$\begin{array}{lccc}\text { Employment protection } & .0376(1.62) & .0118(0.55) & -.0442(0.77) \\ \text { Benefits } & -.0002(0.24) & -.0002(0.35) & -.0002(0.21) \\ \text { Tax wedge } & .0002(0.24) & .0009(1.06) & .0030(1.62) \\ \text { Year dummies } & \text { No } & \text { Yes } & \text { Yes } \\ \text { Country dummies } & \text { No } & \text { No } & \text { Yes } \\ \mathrm{R}^{2} & .9434 & .9540 & .9647 \\ \mathrm{~N} & 480 & 480 & 480\end{array}$

(Dependent variable $=\log$ of unemployment rate $_{t}$ )

In a recent article, Howell et al (2007) econometrically examined the impact of these rigidity variables, or what they call Protective Labor Market Institutions (PLMIs), and concluded that: "while significant impacts for employment protection, benefit generosity, and union strength have been reported, the clear conclusion from our review of these studies is that the effects for the PLMIs is distinctly unrobust, with widely divergent coefficients and levels of significance." Indeed, in his published comments on the Howell et al. article, Jim Heckman (2007) argues that the authors "... are convincing in showing the fragility of the evidence on the role of labour market institutions in explaining the pattern of European unemployment, using standard econometric methodology." Freeman (2007) also finds the evidence for the impact of these institutional variables less than convincing "despite considerable effort, researchers have not pinned down the effects, if any, of institutions on other aggregate economic outcomes, such as unemployment and employment". ${ }^{23}$ In a recent article, Horst Feldmann examined how the quality of industrial relations affects unemployment in developing countries and found relatively moderate effects, especially for females. ${ }^{24}$

There is no evidence in the UK that over the last year or so that union density, benefits, the tax wedge or employment protection has risen. Interestingly, both Spain and Ireland, which have seen big changes in unemployment over the past twenty years (Appendix 1), always had low levels of all of these rigidity variables and these have not increased over time. What is true is that unemployment in Europe is higher than it is in the United States and Western Europe has more job protection, higher unemployment benefits, more union power, and a more generous welfare state. But that is a cross-section correlation and it tells us little or nothing about time series changes.

\footnotetext{
${ }^{23}$ D. Howell, D. Baker, A. Glyn and J. Schmitt (2007), 'Are protective labour market institutions at the root of unemployment? A critical review of the evidence', Capitalism and Society, 2(1), pp. 171. Heckman, J. (2007), 'Comments on 'Are protective labour market institutions at the root of unemployment? A critical review of the evidence by David Howell, Dean Baker, Andrew Glyn and John Schmitt', Capitalism and Society, 2(1), Article 5, pp. 15. R.B. Freeman (2007), 'Labor market institutions around the world', NBER WP\#13242. Blanchflower, D.G. (2001), 'Unemployment, wellbeing and wage curves in Eastern and Central Europe', Journal of the Japanese and International Economies, 15(4), pp. 364-402.

${ }^{24}$ H. Feldmann (2009), 'The quality of industrial relations and unemployment in developing countries', Review of Development Economics, 13(1), pp. 56-69.
} 
The increases in unemployment we have observed in the UK over the last year or so are not due to decreases in labour market flexibility. It is not that frictions in the market have increased: rather, there has been a collapse in the demand for labour as product demand has fallen, which in turn reflects severe credit rationing, falling consumer confidence, responses to transitory shocks in raw materials prices and delayed response by monetary authorities to these developments. None of these issues directly impinge on the labour market or on the extent to which institutional arrangements affect its efficiency.

\section{Why Do We Care About Unemployment?}

The major reasons cited in the literature for why we care about unemployment are as follows:

1) Because of the lost output involved. During a long period of unemployment, workers can lose their skills, causing a loss of human capital.

2) Unemployment is a stressful life event that makes people unhappy. ${ }^{25}$

3) Unemployment increases susceptibility to malnutrition, illness, mental stress, and loss of self-esteem, leading to depression. ${ }^{26}$ Goldsmith, Veum and Darity $(1996,1997)$ found, for example, using data from the NLSY that being jobless injures self-esteem and fosters feelings of externality and helplessness among youths. Moreover, they also found evidence that the psychological imprint of joblessness persists.

\footnotetext{
${ }^{25}$ L. Winkelmann and R. Winkelmann (1998), 'Why are the unemployed so unhappy? Evidence from panel data', Economica, 65(257), pp. 1-15. A.E. Clark and A.J. Oswald (1994), 'Unhappiness and unemployment', Economic Journal, 104(424), pp. 648-659. B.S. Frey and A. Stutzer (2002), Happiness and Economics, Princeton University Press. Ahn, N., J.R. García and J.F. Jimeno (2004), 'The impact of unemployment on individual well-being in the EU', European Network of Economic Policy Institutes, Working Paper No 29.

${ }^{26}$ M. Linn, R. Sandifer and S. Stein (1985), 'Effects of unemployment on mental and physical health', American Journal of Public Health, 75, pp. 502-506. M. Frese and G. Mohr (1987), 'Prolonged unemployment and depression in older workers: a longitudinal study of intervening variables, Social Science and Medicine, 25, pp. 173-178. P. Jackson and P. Warr (1987), 'Mental health of unemployed men in different parts of England and Wales', British Medical Journal, 295, p. 525. M.H. Banks and P.R. Jackson (1982), 'Unemployment and the risk of minor psychiatric disorder in young people: cross-sectional and longitudinal evidence', Psychological Medicine, 12, pp. 789-798. Darity, W.R. Jr. and A.H. Goldsmith (1996), 'Social psychology, unemployment and macroeconomics', Journal of Economic Perspectives, 10(1), Winer, pp. 121-140. A.H. Goldsmith, J.R. Veum and W. Darity (1996), 'The psychological impact of unemployment and joblessness', Journal of Socio-Economics, 25(3), April, pp. 333-358. A.H. Goldsmith, J.R. Veum and W. Darity (1997), 'Unemployment, joblessness, psychological well-being and self-esteem: theory and evidence', Journal of Socio-Economics, 26(2), April, pp. 133-158. M.H. Brenner and A. Mooney (1983), Unemployment and health in the context of economic change', Social Science and Medicine, 17(16), pp. 1125-1138.
} 
4) Increases in the unemployment rate tend to be associated with increases in the suicide rate. ${ }^{27}$ The unemployed appear to have a higher propensity to commit suicide.

5) Being unemployed can also reduce the life expectancy of workers. ${ }^{28}$

6) Unemployment increases the probability of poor physical health outcomes such as heart attacks in later life. ${ }^{29}$

7) The long-term unemployed are at a particular disadvantage trying to find work. ${ }^{30}$ The effects of unemployment appear to depend a lot on how long the person has been unemployed for. People's morale sinks as the duration of unemployment rises. Longterm unemployment is especially harmful. "The long-term unemployed have largely given up hope," (Layard, 1986, p.96). ${ }^{31}$

\footnotetext{
${ }^{27}$ S. Platt (1984), 'Unemployment and suicidal behaviour: a review of the literature', Social Science and Medicine, 19(2), pp. 93-115. C. Pritchard (1992), ' Is there a link between suicide in young men and unemployment? A comparison of the UK with other European Community Countries?', The British Journal of Psychiatry, 160, pp. 750-756. T.A. Blakely, S.C.D. Collings, J. Atkinson (2003), 'Unemployment and suicide. Evidence for a causal association?', Journal of Epidemiology and Community Health, 57, pp. 594600. D.S. Hamermesh and N.M. Soss. 'An economic theory of suicide', Journal of Political Economy, January/February 1974, 82(1), pp. 83-98. D.G. Blanchflower and R.B. Freeman (2000), 'The Declining Economic Status of Young Workers in OECD Countries,' in D.G. Blanchflower and R.B. Freeman (editors), Youth Employment and Joblessness in Advanced Countries, University of Chicago Press and NBER. M.C. Daly, D.J. Wilson and N.J. Johnson (2008), ' Relative status and well-being: evidence from U.S. suicide deaths', Federal Reserve Bank of San Francisco Working Paper 2007-12. http://www.frbsf.org/publications/economics/papers/2007/wp07-12bk.pdf

28 Brenner and Mooney (1984) ibid, K.A. Moser, P.O. Goldblatt, A.J. Fox and D.R. Jones (1987), 'Unemployment and mortality: comparison of the 1971 and 1981 longitudinal study census samples', British Medical Journal; 1, pp.86-90. K.A. Moser, P.O. Goldblatt, A.J. Fox and D.R. Jones (1990), 'Unemployment and mortality' in: Goldblatt P., editor. Longitudinal study: mortality and social organisation. London: OPCS, 1990. (Series LS No. 6.)
}

${ }^{29}$ N. Beale and S. Nethercott (1987), 'The health of industrial employees four years after compulsory redundancy', Journal of the Royal College of General Practitioners, 37 pp. 390-394. L. Iverson and S. Sabroe (1988), 'Participation in a follow-up study of health among unemployed and employed people after a company closedown: drop outs and selection bias,' Journal of Epidemiology and Community Health, 42: 396-401. I. Mattiasson, F. Lindgarde, J.A. Nilsson and T. Theorell (1990), 'Threats of unemployment and cardiovascular risk factors: longitudinal study of quality of sleep and serum cholesterol concentrations in men threatened with redundancy', British Medical Journal, 301, pp. 461-466.

30 S. Machin and A. Manning (1999), 'The causes and consequences of long-term unemployment in Europe', in Handbook of Labor Economics, Volume 3C, edited by O.C. Ashenfelter and D. Card, North Holland

${ }^{31}$ R. Layard (1986), How to beat unemployment, Oxford University Press. 
8) Unemployment while young, especially of long duration, causes permanent scars rather than temporary blemishes. ${ }^{32}$ For the young a spell of unemployment does not end with that spell; it raises the probability of being unemployed in later years and has a wage penalty. These effects are much larger than for older people.

9) As unemployment rates increase, crime rates tend to rise, especially property crime. ${ }^{33}$ Indeed, there is some recent evidence that property crime has now started to increase in the UK. According to the British Crime Survey for the period July to September 2008, police recorded domestic burglaries rose by four per cent. ${ }^{34}$ Thornberry and Christensen (1984), for example, find evidence that a cycle develops whereby involvement in crime reduces subsequent employment prospects which then raises the likelihood of participating in crime. Fougere et al (2006) find that increases in youth unemployment causes increases in burglaries, thefts and drug offences. Hansen and Machin (2002) find a statistically significant negative relationship between the number of offences reported by the police over a two year period for property and vehicle crime and the proportion of workers paid beneath the minimum before its introduction. ${ }^{35}$ Hence, there are more crime reductions in areas that initially, had more low-wage workers. Falk and Zweimuller (2005) find a significant positive relation between unemployment and right-wing criminal activities. Carmichael and Ward (2001) found in Great Britain that youth unemployment and adult unemployment are both significantly and positively related to burglary, theft, fraud and forgery and total crime rates. For each of these offence categories the relationship between youth unemployment and the specific crime was found to be somewhat stronger. Carmichael and Ward (200) found that there is a systematic positive relationship between burglary rates and male unemployment regardless of age. ${ }^{36}$

\footnotetext{
${ }^{32}$ David Ellwood (1982), 'Teenage Unemployment: Permanent Scars or Temporary Blemishes?' in The Youth Labor Market Problem: Its Nature, Causes and Consequences, edited by Richard B. Freeman and David A. Wise, pp. 349-390. Chicago: University of Chicago Press, 1982

${ }^{33}$ T. Thornberry and R. Christensen (1984), 'Unemployment and criminal involvement. An investigation of reciprocal causal structures', American Sociological Review, 56, pp. 609-627. M. Lin (2008), 'Does unemployment increase crime? Evidence from US data, 1974-2000', Journal of Human Resources, 43(2), Spring, pp. 413-436. S. Raphael and R. Winter-Ebmer (2001), 'Identifying the effect of unemployment on crime', Journal of Law and Economics, 44(1), pp. 259-283. D. Fougere, F. Kramarz and J. Pouget (2006) 'Youth unemployment and crime in France', CEPR Discussion paper \# 5600. For a discussion of the relationship between unemployment and crime see R.B. Freeman (1999), 'The economics of crime', in Handbook of Labor Economics, Volume 3C, edited by O.C. Ashenfelter and D. Card, North Holland.
}

${ }^{34}$ Crime in England and Wales Quarterly Update to September 2008, Home Office Statistical Bulletin, Second Edition 01/09, Home Office, $22^{\text {nd }}$ January 2009.

35 K. Hansen and S. Machin (2002), 'Spatial crime patterns and the introduction of the UK Minimum Wage', Oxford Bulletin of Economics and Statistics, 64, pp. 677-699.

36 A. Falk and J. Zweimuller (2005), 'Unemployment and right-wing extremist crime' CEPR Discussion Paper \#4997. F. Carmichael and R. Ward (2001), 'Male unemployment and crime in England and Wales', Economics Letters, 73, pp. 111-115. F. Carmichael and R. Ward (2000), 'Youth unemployment and crime in the English regions and Wales', Applied Economics, 32(5), April, pp. $559-571$. 
10) Increases in the unemployment rate, lowers the happiness of everyone, not just the unemployed. The fear of becoming unemployed in the future lowers a person's subjective wellbeing. ${ }^{37}$

We deal in more detail with a number of these issues below. In particular we look at the health and well being of the unemployed and how increases in the aggregate unemployment rate lowers national wellbeing. First, though, we examine the characteristics of the unemployed and how little they have changed over time.

\section{The Impact of Unemployment on Health and Well-Being in the UK}

We now present econometric evidence of our own on the consequences of unemployment on health and well being in the UK.

\section{a) Mental health}

It is notable that the unemployed are especially likely to report having a mental illness, although it should be said that the direction of causation is unclear. For example, in the Labour Force Surveys from February-September 2008 2.74\% of the unemployed reported their most important health problem, if they had one, was depression or bad nerves compared with $0.73 \%$ of the employed.

There is a growing body of literature that suggests that the unemployed are especially unhappy. ${ }^{38}$ The evidence from around the world is that unemployment hasn't increased because the unemployed are lazy and have chosen not to work because benefits are too high. The reserve army of the unemployed is a conscript army rather than a volunteer army. Table 8 uses data from two Eurobarometer Surveys to model mental health and overall wellbeing across the European Union. In each case an ordered logit is estimated for life satisfaction, happiness, being depressed and feeling 'down in the dumps'. Controls are included for age, gender, schooling, country, marital status and labour market status. In the first two columns the unemployed are less happy. In the final two columns they are especially likely to be 'down in the dumps' and downhearted and depressed'. We also included an interaction term between the UK dummy and the

\footnotetext{
${ }^{37}$ Di Tella R., MacCulloch R.J. and A.J. Oswald (2001), 'Preferences over inflation and unemployment: evidence from surveys of happiness', American Economic Review, 91, pp. 335-341. Di Tella R., MacCulloch R.J. and A.J. Oswald (2003), 'The macroeconomics of happiness', Review of Economics and $\underline{\text { Statistics, }}$ 85, 809-827. D. G. Blanchflower (2007), 'Is unemployment more costly than inflation?', NBER Working Paper W13505, October. D.G. Blanchflower, David (1991), 'Fear, unemployment and pay flexibility', Economic Journal, 101, pp. 483-496. A. Knabe and S. Rätzel (2008), 'Scarring or scaring? The psychological impact of past and future unemployment', Otto-von-Guericke-University Magdeburg, February 21.

${ }^{38}$ See, for example, A. Clark and A. J. Oswald (1994), 'Unhappiness and unemployment', Economic Journal, May, 104(424), pp. 648-659; L. Winkelmann and R. Winkelmann (1998), 'Why are the unemployed so unhappy? Evidence from panel data', Economica, 65(257), pp. 1-15 and D.G. Blanchflower and A.J. Oswald (2004), 'Well-being over time in Britain and the United States', Journal of Public Economics, Volume 88, Issues 7-8, July, pp. 1359-1386.
} 
unemployment dummy which was insignificant in columns 2 and 4, weakly significant in column $1(\mathrm{t}=1.61)$ and significant in column $3(\mathrm{t}=1.99)$ suggesting that the unemployed in the UK are significantly more 'down in the dumps' than in other countries. Losing a job makes people unhappy, depressed and 'down in the dumps'.

\section{b) Job satisfaction and the fear of job loss}

Workers have lower levels of job satisfaction if they fear they are about to lose their jobs. Table 9 estimates a series of job satisfaction equations, across European countries using data from the European Working Conditions Survey of 2005 across 31 countries. Respondents were asked - Q36 On the whole, are you very satisfied, satisfied, not very satisfied or not at all satisfied with working conditions in your main paid job? Answers were coded as follows 4 - Very satisfied; 3 - Satisfied; 2 - Not very satisfied; 1 - Not at all satisfied. This is the dependent variable in Table 9. Workers were also asked (Q37a) 'How much do you agree or disagree with the following statements describing some aspects of your job? - I might lose my job in the next 6 months - Strongly agree; Agree; Neither agree nor disagree; Disagree; Strongly disagree?". Separate controls are included for each of these answers. Satisfaction is higher among the old, females, the self-employed without employees, whites and workers in small firms. Most importantly for our purposes the greater the degree of perceived job insecurity, the less satisfied the worker was. The significant and negative coefficients on the three UK*lose job interaction terms suggest these effects were especially pronounced in the UK. So increased job insecurity lowers workers' satisfaction levels.

\section{c) Impacts of rising unemployment rates on those who are not unemployed}

When unemployment rises, happiness of both workers and non-workers falls. Unemployment affects not only the mental wellbeing of those concerned, but also that of their families, colleagues, neighbours and others who are in direct or indirect contact with them. Jones and Fletcher (1993), for example, provide evidence that the occupational stress and distress from unemployment can be transmitted between partners ${ }^{39}$

There is a body of literature that suggests individual wellbeing is related also to aggregate macroeconomic variables such as the unemployment rate, inflation, and the

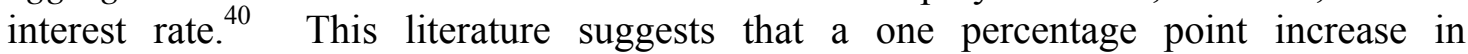
unemployment reduces overall happiness twice as much as an equivalent one percentage point increase in inflation - the so-called misery index. Moreover, increases in aggregate unemployment seems to indirectly reduce the wellbeing of not just the unemployed but also that of the employed and those out of the labour force such as students, the retired and those looking after the home.

\footnotetext{
${ }^{39}$ F. Jones and B. Fletcher (1993): 'An empirical study of occupational stress transmission in working couples', Human Relations, 46, 881-903.

${ }^{40}$ R. Di Tella, R, MacCulloch, and A. Oswald (2001): 'Preferences over inflation and unemployment: evidence from surveys of happiness', American Economic Review, 91, pp. 335-341 and D.G. Blanchflower (2007), 'Is unemployment more costly than inflation?', NBER Working Paper No. 13505.
} 
Table 10 uses data from a cross country panel estimates the impact of the country level unemployment rate as well as the inflation rate on reported life satisfaction using micro data at the level of the individual from the 1973-2006 Eurobarometers for 19 European countries. Standard errors are clustered at the country*year level. Life satisfaction is reported in four steps as in Table 8, with the unweighted proportions for the UK in parentheses - very satisfied (32\%); fairly satisfied (54\%) not very satisfied (10\%) and not at all satisfied (3\%). Column 1 is taken from Blanchflower (2007) and suggests that the unemployed are less happy but also a higher unemployment rate and a higher inflation rate lowers happiness. ${ }^{41}$ Column 2 includes an interaction term between being unemployed and the unemployment rate suggesting that a higher unemployment rate lowers the happiness of the unemployed more than other groups. This is confirmed in columns 3-5 where the coefficient on the unemployment rate is greater for the unemployed (column 3) than it is for either the employed or those out-of-the-labour-force (OLF). This is consistent with the findings of Di Tella et al (2001) who also find that increases in the national unemployment rate have much larger effects on the happiness of the unemployed than they do for the employed using the Eurobarometer life satisfaction data for twelve EU countries from 1975-1992. ${ }^{42}$ This result, however, contrasts with the findings of Clark (2003) using BHPS panel data for the UK and Clark et al (2008) using data from the German Socio-Economic Panel who find that the well-being of the unemployed is less affected by unemployment if they live in a region with a high unemployment rate, thus narrowing the well-being gap between the employed and unemployed in such regions. ${ }^{43}$

As a check on this result we examined the data from the General Social Survey for the US for 1972-1998 used in Blanchflower and Oswald (2004). We re-estimated the ordered logit model reported in column 1 of Table 4 where the dependent variable was how happy you are (not very happy; quite happy and very happy). Controls were a time trend; labor market status (8); marital status (8); race dummies (2); years of education; age and its square and gender. We added a full set of (45) state dummies and the log of

\footnotetext{
${ }^{41}$ Blanchflower (2007) uses the data in column 1 of Table 8 to estimate a misery index of 1.62 , which is the marginal rate of substitution between inflation and unemployment. The entire well-being cost of a 1 percentage-point increase in the unemployment rate is therefore given by the sum of two components - the unemployment rate $(-.011)$ and the loss of wellbeing of the unemployed themselves $(-.363 * .01)$. Combining the two, we have $.0110+.0036=.0146$ as society's overall wellbeing cost of a one percentage point rise in the unemployment rate. That is then divided by the coefficient on the inflation rate of .009 . hence, $(0.0146 / 0.0090)=1.62$, where 0.0146 is the marginal unemployment effect on well-being, and 0.0090 is the marginal inflation effect on well-being. Hence a 1 percentage point increase in unemployment lowers wellbeing by 1.62 times the impact of a one percentage point increase in inflation. People care more about unemployment than they do about inflation.
}

${ }^{42}$ R. Di Tella, R. MacCulloch and A.J. Oswald (2001), 'The macroeconomics of happiness', Review of Economics and Statistics, 85, 809-827.

${ }^{43}$ Clark, A.E. (2003): 'Unemployment as a social norm: psychological evidence from panel data', Journal of Labor Economics, 21, 323-351. A.E. Clark, A. Knabe and S.Rätzel (2008), 'Boon or bane? Others' unemployment, well-being and job insecurity', CESIFO working paper \# 2501, December. 
the state unemployment rate - there are 45 dummies here due to the coverage of the GSS. For simplicity OLS results are reported below. We present three results. First, for all respondents and here unemployment lowers happiness as does the state unemployment rate. In column 2 we add an insignificant interaction term between the unemployment dummy and the state unemployment rate, which is insignificant, as it is in the final column, which is restricted to the workforce.

$\begin{array}{llcl} & \text { All } & \text { All } & \text { Workforce } \\ \text { Unemployed dummy } & -.25(12.9) & -.22(2.0) & -.23(2.1) \\ \text { Log of state unemployment } & -.04(3.8) & -.05(3.8) & -.05(2.9) \\ \text { Unemployed* log state U } & & -.02(0.3) & -.02(0.3) \\ \mathrm{N} & 35,930 & 35,930 & 23,066\end{array}$

Interestingly Luechinger et al (2008) also used the GSS data to show that the sensitivity of subjective well-being to fluctuations in unemployment rates is much lower among employees in the public sector than in the private. They found a similar result using individual panel data for Germany from the GSOEP 1984-2004 and repeated crosssectional data for thirteen European countries from the Eurobarometers 1989-1994. The fear of unemployment is, as expected, greater for workers in the private sector than in the public sector. This, the authors argue, suggests that "increased economic insecurity constitutes an important welfare loss associated with high general unemployment". ${ }^{44}$

We now turn to examine the youth labour market that, as we noted above, is especially impacted in downturns.

\section{What are the Characteristics of the New Unemployed?}

Another key comparison with past recessions is how the incidence of unemployment is distributed across the population. Historically, the unemployed have been concentrated in particular regions or industries; it has fallen most heavily on particular groups in society such as the young, the old, those with a non-white ethnic background and those whose partner was not working. Will these patterns be repeated in this recession? Clearly, it is relatively early to draw strong conclusions about the course of a recession that is in its ninth month. However, some trends are emerging in the claimant count unemployment data that are already worthy of comment.

Because recessions influence the components of demand differently, their effects of are rarely uniform across industrial sectors. Thus, if investment falls more rapidly than other components of demand, the construction and investment goods industries are likely to be more affected than other sectors. Since industries are not uniformly distributed across the country, particular regions and localities will experience a more rapid rise in unemployment than elsewhere. In this section, we consider this issue at the regional,

\footnotetext{
${ }^{44}$ S. Luechinger, S. Meier and A. Stutzer (2008), 'Why does unemployment hurt the employed? Evidence from the life satisfaction gap between the public and the private sector?', IZA DP No. 3385, March.
} 
travel-to-work area and city level. We also examine the incidence of unemployment categorized by age, ethnicity and household composition.

\section{a) Regions}

The large increases in unemployment during the 1970s and 1980s were focused on the north of England, Scotland and Wales. The recession of the early 1990s followed a very different pattern and, thus far, the same is true of the present downturn. Figure 11 shows the percentage increase in claimant count unemployment for 8 months from the beginning of the recession which commenced in April 1991 plotted against the percentage increase in unemployment over the first 8 months of the present recession (Apr-Nov 2008). It shows that, with the exception of London, the growth in unemployment at the start of the last two recessions has been concentrated in the South of England. This may reflect the relatively greater size of the housing asset bubble in the south. Interestingly, Northern Ireland experienced much more rapid growth in the value of its housing during 2005 and 2006 than it did during the housing boom of the late 1980s and its unemployment has risen particularly sharply during 2008 compared with $1991{ }^{45}$

The relationship between the increase in unemployment in 1991 and that in 2008 is positive and significant, perhaps suggesting that there is some common causal pattern between both recessions. The most likely culprit, present in both recessions, is a sudden reversal in house prices, brought about by an unsustainable bubble in these prices.

At a more disaggregated level, the positive relationship between increases in unemployment during the early 1990s and 2008 is still evident. Figure 12 shows a scatter of percentage increases in claimant count unemployment during the first 8 months of the 1991 and 2008 recessions for all British travel-to-work areas (TTWAs). Again, there is a strongly positive relationship $(t=8.0)$, but the increase in 1991 only explains 18 per cent of the variation in TTWA unemployment in 2008. Hence, while both recessions may both partly be explained by the asset price bubble, there are clearly other causal factors which the recessions do not share.

As one would expect, given the regional data, the percentage increase in unemployment in 2008 was greater in the towns and cities in the south that have previously been associated with rapid growth and development. Thus, Swindon, Reading, Exeter and Bristol have experienced more rapid increases in unemployment than northern towns such as Leeds, Manchester and Liverpool. This raises interesting questions about the extent to which a city-based growth strategy can be undermined by excess pressure in the local housing market.

\footnotetext{
${ }^{45}$ Though one should note that there is a considerable debate about whether there have been bubbles in UK house prices in the sense of house prices significantly deviating from those prices dictated by the fundamentals of the housing market see Cameron, G., Muellbauer, J., and Murphy, A. (2006), 'Was there A British house price bubble? Evidence from a regional panel', University of Oxford, Department of Economics Working Paper No 276
} 
b) Age, schooling, race and gender

Of interest also is who are the unemployed and how have their characteristics changed over time Micro-data at the level of the individual are used in this section drawn from separate Labour Force Surveys for 1984, 1993 and 2006, 2007 and 2008 up to September. The first LFS in the UK was conducted in 1973, under a Regulation derived from the Treaty of Rome. The survey was carried out every two years from 1973 to 1983 in the spring quarter. Between 1984 and 1991 the survey was carried out in the quarter between March and May, in Great Britain and Northern Ireland. From the spring of 1992 sample sizes were increased as the survey was taken in all calendar months. Each quarter's LFS sample of 57,000 UK households is made up of five "waves", each of approximately 11,000 private households. Each wave is interviewed in five successive quarters, such that in any one quarter, one wave will be receiving their first interview, one wave their second, and so on, with one wave receiving their fifth and final interview. Thus there is an $80 \%$ overlap in the samples for each successive quarter. Consequently the sample size in 1984 is considerably smaller $(n=67,000)$ than it is in 1993 $(\mathrm{n}=284,000) ; 2006(\mathrm{n}=229,000) ; 2007(226,000)$ or $2008(\mathrm{n}=164,000)$ where data are only available until September.

Initially we focus on the most current unemployment rates. Below are the weighted rates (\%) by sub-group for the period April-September 2008. Youth rates (18-24) are generally more than double the overall rates.

\begin{tabular}{lcc|lcr} 
& All ages & $\mathbf{1 8 - 2 4}$ yrs & & All ages & $\mathbf{1 8 - 2 4}$ yrs \\
Overall & 5.8 & 13.4 & Rest of North & 6.3 & 13.4 \\
Male & 6.2 & 15.6 & South Yorkshire & 8.2 & 19.3 \\
Female & 5.2 & 11.0 & West Yorkshire & 6.8 & 15.2 \\
White & 5.2 & 12.5 & Rest Yorks/Humber & 3.8 & 7.7 \\
Black & 13.3 & 26.3 & East Midlands & 5.8 & 13.6 \\
Asian & 9.7 & 21.3 & East Anglia & 4.7 & 11.6 \\
No qualifications & 11.6 & 28.9 & Inner London & 8.0 & 19.0 \\
Apprenticeship & 3.2 & 6.2 & Outer London & 6.4 & 15.6 \\
O-level & 7.1 & 15.1 & Rest of South East & 4.4 & 11.0 \\
ONC/OND & 5.3 & 15.4 & South West & 4.0 & 8.2 \\
A-level & 5.9 & 10.7 & West Midlands & 8.7 & 18.4 \\
HNC/HND & 2.6 & 8.7 & Rest West Midlands & 4.5 & 10.3 \\
Degree & 3.4 & 11.3 & Greater Manchester & 7.6 & 16.5 \\
First & 2.9 & 6.8 & Merseyside & 8.9 & 20.7 \\
IIi & 3.7 & 8.7 & Rest of North West & 5.0 & 12.8 \\
IIii & 3.5 & 11.3 & Wales & 5.8 & 12.0 \\
III & 3.5 & 14.6 & Strathclyde & 5.4 & 11.7 \\
Pass & 3.4 & 17.5 & Rest of Scotland & 4.0 & 10.0 \\
Higher degree & 2.4 & 9.3 & Northern Ireland & 4.3 & 11.8 \\
Tyne \& Wear & 7.9 & 16.2 & & &
\end{tabular}

It is apparent that unemployment rates decline with age, are higher among men, minorities and the least educated. Unemployment rates for 18-24 year olds are lower the 
higher the class of degree obtained and especially so for those with a first. Unemployment is especially prevalent among those aged 18-24 who do not have any qualifications. Youth unemployment rates are highest in the regions that have the highest overall rates of unemployment (Merseyside, South Yorkshire and Inner London) and vice versa. The distribution of highest education qualifications in 2008 is reported below.

Degree or equivalent

Other higher ed.

A level

GCSE grades A-C

Other qualifications

No qualifications

$\begin{array}{cc}\text { Employed } & \text { Unemployed } \\ 24 & 14 \\ 10 & 4 \\ 24 & 19 \\ 22 & 28 \\ 13 & 17 \\ 8 & 17\end{array}$

The employed are more highly educated but what stands out is just over a third of the unemployed have A-levels or higher. This contrasts sharply with 1984 when, based on our examination of the LFS, at that time more than half of the unemployed had no qualifications while only $2 \%$ of the unemployed had a degree or higher degree.

\section{c) Occupation}

The current downturn is not just a blue-collar recession. This is confirmed when one looks at the occupation distributions. Below we report the distributions (\%) of the current occupations of the employed and the last occupation of the unemployed in 2008. Note that one third of the unemployed (31.8\%) had not had an occupation in the preceding eight years, and these are excluded from the distribution. We are struck by the similarity of the distributions rather than by their differences.

Managers and senior officials

Professional occupations

Associate professional and technical

Administrative and secretarial

Skilled trades occupations

Personal service occupations

Sales and customer service occupation

Process, plant and machine operatives

Elementary occupations

$\begin{array}{cc}\text { Current Workers } & \text { Unemployed } \\ 16 & 11 \\ 13 & 9 \\ 15 & 9 \\ 11 & 13 \\ 11 & 9 \\ 8 & 10 \\ 8 & 11 \\ 7 & 9 \\ 12 & 20\end{array}$

d) Industry

If we examine the most recent data on the reduction in workforce jobs, it is apparent that there has been a decline in the numbers employed in Finance, Business and Services and Distribution, Hotels and Restaurants. A puzzle in the data is the fact that there has been no contraction in the numbers working in construction. This may in part be explained by the fact that approximately $40 \%$ of the most recent increase in unemployment is from the self-employed who disproportionately work in construction. In the LFS the unemployed report their last industry and the distributions are below, for those who have ever worked 
(\%) alongside the employed for 2008. The puzzle is also there in the unemployment data because the construction industry proportion seems low. The important role played by migrants in this sector and the extent to which they are adequately sampled in the LFS may also contribute to an explanation.

Agriculture, hunting \& forestry

$\begin{array}{cc}\text { Employed } & \text { Unemployed } \\ 1.45 & 0.93 \\ 0.05 & 0.02 \\ 0.44 & 0.31 \\ 12.22 & 15.51 \\ 0.70 & 0.42 \\ 8.02 & 9.69 \\ 14.66 & 19.75 \\ 4.24 & 8.96 \\ 6.68 & 7.61 \\ 4.11 & 2.76 \\ 11.81 & 10.05 \\ 7.27 & 3.72 \\ 9.44 & 4.88 \\ 12.80 & 8.47 \\ 5.56 & 6.24 \\ 0.49 & 0.46 \\ 0.04 & 0.03 \\ 0.02 & 0.20\end{array}$

Fishing

Mining, quarrying

Manufacturing

Electricity gas \& water supply

Construction

Wholesale, retail \& motor trade

Hotels \& restaurants

Transport, storage \& communication

Financial intermediation

Real estate, renting etc

Public administration \& defence

Education

Health \& social work

Other community, social \& personal

Private households with employed persons

Extra-territorial organisations

Workplace outside UK

0.02

0.20

\section{e) Time series changes in characteristics}

A comparison of how unemployment rates have changed over time, are reported below in the first row using ONS data (see also Figure 1). The remaining rows report on the changing characteristics based on the (unweighted) means from our LFS data files. The earlier two years of 1984 and 1993 were chosen, as these were the high points of unemployment in earlier cycles and thus the depth of the two prior recessions and hence provide a useful basis for comparison. ${ }^{46}$

$\begin{array}{lrcccc} & 1984 & 1993 & 2006 & 2007 & 2008 \\ \text { Overall } & 11.8 & 10.4 & 5.4 & 5.3 & 5.8 \\ & & & & & \\ \text { Degree } & 4.2 & 4.5 & 3.1 & 2.5 & 2.9 \\ \text { O-level } & 9.4 & 9.8 & 5.9 & 6.3 & 6.5\end{array}$

\begin{tabular}{|c|c|c|c|c|c|c|c|c|c|c|c|c|c|}
\hline 1971 & 4.1 & 1977 & 5.6 & 1983 & 11.5 & 1989 & 7.2 & 1995 & 8.6 & 2001 & 5.1 & 2007 & 5.3 \\
\hline 1972 & 4.3 & 1978 & 5.5 & 1984 & 11.8 & 1990 & 7.1 & 1996 & 8.1 & 2002 & 5.2 & 2008Q3 & 5.8 \\
\hline 1973 & 3.7 & 1979 & 5.4 & 1985 & 11.4 & 1991 & 8.9 & 1997 & 6.9 & 2003 & 5.1 & $2008 \mathrm{Nov}$ & 6.1 \\
\hline 1974 & 3.7 & 1980 & 6.8 & 1986 & 11.3 & 1992 & 9.9 & 1998 & 6.3 & 2004 & 4.8 & & \\
\hline 1975 & 4.5 & 1981 & 9.6 & 1987 & 10.4 & 1993 & 10.4 & 1999 & 6.0 & 2005 & 4.9 & & \\
\hline y/ & 5.4 & 1982 & 0.1 & 15 & 8.0 & 94 & 9.5 & 2000 & 5.4 & 2006 & 5.4 & & \\
\hline
\end{tabular}




$\begin{array}{lrrrrr}\text { No qualifications } & 13.9 & 14.6 & 9.8 & 10.2 & 10.6 \\ 16-17 & 21.3 & 24.0 & 24.2 & 26.4 & 25.5 \\ 18-24 & 18.0 & 17.6 & 12.2 & 12.1 & 12.9 \\ \text { Black } & 20.8 & 27.2 & 13.3 & 12.2 & 12.5 \\ \text { Asian } & 19.3 & 20.2 & 10.1 & 9.6 & 9.8 \\ \text { Black<25 yrs of age } & 31.5 & 44.9 & 33.0 & 33.7 & 33.4\end{array}$

The main points that stand out are that unemployment is higher among the less educated, the young and blacks and especially young blacks. That pattern is consistent in each of the years. Unemployment starts to rise for all groups in 2008. Unemployment for blacks was considerably worse in 1984 and 1993. Somewhat surprisingly the unemployment rate of young blacks in 2008 is higher than in 1998.

\section{e) Econometric estimates of the probability of being unemployed}

Table 6 uses the LFS data from these five sample years to model econometrically the probability of an individual in the labour force being unemployed, so the employed are set to zero and one if unemployed. Anyone who is OLF is excluded so the sample is restricted to the workforce. Dprobits are estimated using STATA. ${ }^{47}$ Of particular interest is the age group 18-24 so we present separate estimates in each case for all ages and separately for these young people.

Columns 1 and 2 of Table 6 are for 1984 and columns 3 and 4 for 1993. In each case an overall equation is presented along with one for 18-24 year olds only. The estimates for the two years look very similar, and confirm our findings from the means above that unemployment is higher among men, the least educated, among minorities and in the North of England and Merseyside. Race effects are especially pronounced among the young. Conditional on other characteristics, the probability of unemployment is lowest in the South East.

Table 7 performs a similar exercise for 2006-2008. These equations also include month dummies and three controls for disability. Those who are disabled according to the Disability Discrimination Act (DDA) with a work limitation are especially likely to be unemployed. It is striking how similar the equations look compared to those for 1984 and 1993. Once again unemployment is highest among the young, women, whites and the least educated, and the situation is worsening. The size of the coefficients is increasing over time: the data for 2008 are becoming more like the data for 1984 and 1993. The size of the coefficient on the 16-17 dummy in 2008 is larger than in either 1984 or 1993 at the depth of the two prior recessions. That for 18-24 is smaller but rising and that is the case for most other variables including those on race, gender ad education.

\footnotetext{
${ }^{47}$ The STATA procedure dprobit fits maximum-likelihood probit models and is an alternative to probit. Rather than reporting the coefficients, dprobit reports the marginal effect, that is the change in the probability for an infinitesimal change in each independent, continuous variable and, by default, reports the discrete change in the probability for dummy variables.
} 
It is notable that the regional pattern of coefficients in 2008, are similar to the prior recessions. The ranking, where the highest rate ranks first and the one with the lowest ranks $17^{\text {th }}$, is as follows. Here we re-estimated the data for 2008 merging Inner and Outer London to form 'London' and Strathclyde and the Rest of Scotland to form 'Scotland'.

$\begin{array}{lccc} & \mathbf{1 9 8 4} & \mathbf{1 9 9 3} & \mathbf{2 0 0 8} \\ \text { East Anglia } & 16 & 15 & 13 \\ \text { East Midlands } & 13 & 17 & 10 \\ \text { Greater Manchester } & 8 & 7 & 5 \\ \text { London } & 15 & 5 & 7 \\ \text { Merseyside } & 1 & 1 & 1 \\ \text { North/Tyne \& Wear } & 2 & 2 & 3 \\ \text { Rest North West } & 10 & 14 & 12 \\ \text { Rest of North } & 5 & 6 & 6 \\ \text { Rest South East } & 17 & 16 & 15 \\ \text { Rest West Midlands } & 9 & 13 & 14 \\ \text { Rest Yorks \& Humber } & 11 & 10 & 17 \\ \text { South West } & 14 & 12 & 16 \\ \text { South Yorkshire } & 4 & 3 & 2 \\ \text { Scotland } & 3 & 8 & 11 \\ \text { Wales } & 6 & 9 & 8 \\ \text { West Midlands } & 7 & 4 & 4 \\ \text { West Yorkshire } & 12 & 11 & 9\end{array}$

It is apparent that the regions with the lowest rates in all three years are the Rest of the South East, East Anglia and the South West. Those with the highest are Merseyside the Northern region. The most notable difference is the 2008 recession is hitting London with its dependence on the financial sector, as it did in 1993. The biggest difference is that it is relatively muted in Scotland.

\section{The Youth Labour Market}

We now move on to consider the characteristics of the youth labour market. We first document the changes that have occurred in the UK over recent years, and in particular the growth in the unemployment rate of the young and the substantial rise in the size of the cohort. We then place these changes in international context, and show in particular how the ratio of youth to adult rates is very high in the UK compared to most other countries, developed and developing, in the world. Third, we show that youth labour markets are highly cyclically volatile. Fourth, we examine the extent to which industrial change impact young people's labour market prospects. Fifth, we find that youths do not appear to have priced themselves out of jobs. Finally, we present evidence that unemployment while young creates permanent scars.

a) The nature of the youth labour market problem in the UK

It is noteworthy that the majority of measured youth unemployment in the UK primarily relates to 18-24 year olds (the young) rather than to 16-17 year olds (the very young). For example, in 2008 Q3 there were 184,000 unemployed 16 and 17 year olds compared 
with 597,000 18-24 year olds. There were 331,000 claimants who were 18-24 but none who were $16-17$ as they are not eligible to claim unemployment benefits. The representation of youngsters under the age of twenty five among the unemployed is much greater than their representation in the overall population. ${ }^{48}$

It should also be pointed out that 18-24 year old unemployment has constituted a rising share of overall unemployment since the turn of the millennium. As can be seen below despite a declining overall unemployment rate and a declining rate for the young between 1993 and 2004 their unemployment rate has risen since then. Moreover, their share of unemployment has risen steadily from $21.7 \%$ in 1999 to $29.2 \%$ in 2008 Q3.

$\begin{array}{lrcc} & \text { Unemployment rate } & 18-24 \text { unemployment rate } & 18-24 \text { as \% overall } \\ 1993 & 10.4 & 17.5 & 25.0 \\ 1994 & 9.5 & 16.3 & 23.9 \\ 1995 & 8.6 & 15.0 & 23.1 \\ 1996 & 8.1 & 14.3 & 22.7 \\ 1997 & 6.9 & 12.9 & 22.3 \\ 1998 & 6.3 & 12.0 & 22.8 \\ 1999 & 6.0 & 11.2 & 21.7 \\ 2000 & 5.4 & 10.6 & 22.4 \\ 2001 & 5.1 & 10.4 & 23.9 \\ 2002 & 5.2 & 10.5 & 23.8 \\ 2003 & 5.1 & 10.6 & 24.8 \\ 2004 & 4.8 & 10.4 & 26.2 \\ 2005 & 4.9 & 11.0 & 27.8 \\ 2006 & 5.4 & 12.2 & 27.7 \\ 2007 & 5.3 & 12.3 & 28.3 \\ 2008 \text { Q3 } & 5.8 & 13.7 & 29.2 \\ 2008 \text { Nov } & 6.1 & 14.5 & 31.9\end{array}$

A particular concern is also that youth unemployment rates are particularly high for racial minorities. As we noted above, black unemployment rates ages $18-24$ were $26.3 \%$ and for Asians were $21.3 \%$. The rate for those without qualifications in the 2008 LFS was also high at $28.9 \%$ and $47.4 \%$ for young blacks, $30.0 \%$ for young whites and $38.3 \%$ Asians respectively, without qualifications. We have special concerns regarding the employment prospects of these young people without qualifications- the disadvantaged young - going forward.

Part of the explanation for the rise in youth unemployment in the UK has been the recent rise in the size of the youth cohort. In the latest labour market release by the ONS, unemployment in the Aug-Oct quarter of 2008 increased by 137,000 compared with the

\footnotetext{
${ }^{48}$ In $200715-24$ year olds constituted $13.37 \%$ of the population and $20.15 \%$ of the population of working age (15-64M/59F). See Table 1.4 Population Trends, No 134, Winter 2008.

http://www.statistics.gov.uk/StatBase/Product.asp?vlnk=6303
} 
previous quarter; of this 55,000 were $18-24$ year olds $(40 \%){ }^{49}$ In the same release, claimant unemployment increased by 75,700 on the month of which $22,100(29 \%)$ were 18-24 year olds. This has arisen in part because of the increase in the size of the youth cohort. This is illustrated below:

$\begin{array}{cccc} & \begin{array}{c}\text { Total UK population } \\ (' 000 \mathrm{~s})\end{array} & \begin{array}{c}\# 16-24 \text { year olds } \\ (' 000 \mathrm{~s})\end{array} & 16-24 \text { as \% total } \\ 1981 & 56,357 & 8,079 & 14.3 \% \\ 1986 & 56,684 & 8,332 & 14.7 \% \\ 1991 & 57,439 & 7,491 & 13.0 \% \\ 1996 & 58,164 & 6,495 & 11.2 \% \\ 2000 & 58,886 & 6,383 & 10.8 \% \\ 2001 & 59,113 & 6,504 & 11.0 \% \\ 2002 & 59,323 & 6,632 & 11.2 \% \\ 2003 & 59,557 & 6,785 & 11.4 \% \\ 2004 & 59,846 & 6,960 & 11.6 \% \\ 2005 & 60,238 & 7,099 & 11.8 \% \\ 2006 & 60,587 & 7,221 & 11.9 \% \\ 2007 & 60,975 & 7,368 & 12.1 \%\end{array}$

Source: Population Trends, 134, Winter 2008, Table 1.4.

From 1980 to 2000 the absolute and relative size of the youth cohort shrank. However, since 2000 the size of the youth cohort - the children of the baby boomers - has grown steadily, from 6.4 million (10.8\% of the population) in 2000 to 7.4 million $(12.1 \%)$ in 2007. The growth of the 16-24 cohort has thus been faster than the overall growth in the population. The number of 16-24 year olds in 2007 is still around seven hundred thousand less than the number in 1981 ( 8.1 million). However, the size of that cohort will decline quite rapidly. The following numbers are taken from Key Population and Vital Statistics, 2006 and they show the numbers of children by single year of age (in thousands) in mid 2006.

\begin{tabular}{lccc} 
Age in 2006 & Cohort size ('000s) & Age in 2006 & Cohort size ('000s) \\
0 & 732 & 13 & 759 \\
1 & 716 & 14 & 785 \\
2 & 705 & 15 & 800 \\
3 & 681 & 16 & 791 \\
4 & 663 & 17 & 791 \\
5 & 664 & 18 & 809 \\
6 & 680 & 19 & 805 \\
7 & 700 & 20 & 810 \\
8 & 713 & 21 & 825 \\
9 & 732 & 22 & 808 \\
\hline
\end{tabular}

${ }^{49}$ Labour Market Statistics, First Release, ONS, December 2008, Tables 9(1) and 11(1). 
The growth of the age 16-24 cohort is a temporary phenomenon. It will start to decline in absolute and relative size from 2009 onwards as the larger older cohorts drop out and the younger smaller ones are added. For example, in 2009 there are approximately 825,000 24 year olds (age 21 in 2006) who will drop out and will be replaced by 749,000 fifteen year olds (aged 12 in 2006) so the cohort will shrink by around 75,000. Analogously, it will drop by a similar number the next year.

Of particular concern is the high proportion of young people in the UK who are either not in education employment or training (NEET) or not in education and training (NET). In 2008 Q3 there were 87,000 16 year olds, 216,000 17 year olds and 292,000 individuals classified as NEET (http://www.desf.gov.uk/rsgateway/DB/STA/t000751/index.shtml). Low-skilled youth who become NEET find it more difficult to re-engage in employment and learning than 16-24-year olds on average and there is evidence that they may become trapped in NEET. Godfrey et al (2002) estimated the costs of being NEET for the Department for Education and Skills. ${ }^{50}$ They considered social costs as well as public finance costs over the current, medium and long-term. These included estimates of the costs of educational underachievement, unemployment, inactivity, crime and health. The authors were not able to estimates of the costs of the lowering of the skills base and hence their findings may underestimate the full costs. Their major finding was that the 157,000 NEETs aged 16-18 present in the UK population in 1999 would accrue additional lifetime costs of around $£ 7 \mathrm{bn}$ (2001 prices) in resource terms and $£ 8.1 \mathrm{bn}$ in additional public spending. The per capita equivalents are $£ 45,000$ in resource costs and $£ 52,000$ in public finance costs.

\section{b) International comparisons}

Detailed comparisons of changes in unemployment rates, employment/population rates and participation rates for 15-24 year olds by OECD country are reported in Appendix Tables B and C. In contrast to the finding that youth unemployment had increased in the UK, the ILO (2008) noted that there has been a declining trend in youth unemployment around the world. ${ }^{51}$ The world unemployment rate of youth ages $15-24$ rose from $10.9 \%$ in 1999 to a peak in 2004 of 12.6\% and has declined since then (Table 11). In 2007 the youth unemployment rate stood at $11.9 \%$. The ILO noted that the youth rate was nearly three times the adult rate but 2.4 times in the developed world. We added data for the UK in the final row of the table. It is apparent that, in contrast to the rest of the world, the trend in youth unemployment has been rising in the UK, as has the ratio of youth-to-

\footnotetext{
${ }^{50}$ Godfrey, C., Hutton, S., Bradshaw, J., Coles, B., Craig, G. and Johnson, J., (2002), Estimating the Cost of Being 'Not in Education, Employment or Training' at Age 16-18, Research Report 346, Department for Education and Skills.

${ }^{51}$ ILO (2008), 'Global employment trends for youth', October, ILO Geneva.
} 
adult rates. Worryingly in the latest data for 2008 Q3 we calculate that the youth unemployment rate for 16-24 year olds was $16.8 \%$ and the ratio of youth-adult rates had risen further from 3.9 in 2007 to 4.2 .

The United Nations (2007) in their Annex Table 8, which is presented as Appendix Table $\mathrm{D}$, confirms the finding of high youth unemployment rates and high youth-to-adult rates in the UK. ${ }^{52}$ The ratio of youth to adult unemployment rates in the UK they estimated at 3.6 in 2005, which, in Europe was only exceeded by Malta (3.7), Italy (3.9), Sweden (3.8) and Iceland (4.5) and joint sixteenth with Costa Rica and Haiti out of 117 countries. Outside Europe, New Zealand was the only OECD country with a higher ratio (3.8). The share of unemployed youth in total unemployment, the United Nations noted, is also high at $38.6 \%$ and is exceeded only by Iceland and Malta in Europe.

It is also notable that the proportion of the young who are in full-time education has increased over time. This has increased from $26 \%$ in 1993 to $38 \%$ in 2007 . It is apparent though that the proportion is still well below that of many other countries. It is also apparent that working while in school is becoming a more important part of school-towork transition than the traditional model of school, then work. Data available from the OECD suggests that the proportion of the young who are in school is considerably higher in, for example, Belgium (60\%); Finland (56\%); France (61\%), Italy (57\%); Luxembourg $(69 \%)$ and Sweden (57\%). One response to rising unemployment on the part of youth has been to return to full-time education (Blanchflower and Freeman, 2000, Rice, 1999). ${ }^{53}$

One effect of the increased participation in further education is that the 16-24 cohort are now much better qualified than they were during the last recession. Thus, for example, in 1993, 5.8 per cent of 16-24 year olds were graduates, while in 2008 that share had risen to 13.2 per cent. Interestingly, the improvement in qualifications is more concentrated among females than males. By 2008, the proportion of females aged 18-24 with no qualifications had fallen to 4.6 per cent, but for males was still over 7 per cent. Reflecting the generally higher skills profile among females, it is also worth noting that mean hourly wages for females are higher than those for males among this age group, though not significantly so (Source: LFS).

The OECD (2008b) recently also noted that, even before the slowing of the UK labour market in the spring of 2008, a variety of indicators of youth performance between 2005 and 2007 do paint a more mixed picture (Table 11). ${ }^{54}$ On the one hand, they noted that the youth employment rate is 12 percentage points higher than in the OECD on average

52 United Nations (2007), 'The world youth report 2007—young people's transition to adulthood: progress and challenges', United Nations (http://www.un.org/esa/socdev/unyin/documents/wyr07 complete.pdf).

${ }^{53}$ P. Rice (1999), 'The impact of local labour markets on investment in higher education: evidence from the England and Wales Youth Cohort Studies', Journal of Population Economics, 12, pp. 287-312.

${ }^{54}$ OECD (2008b), Jobs for Youth - United Kingdom, OECD, Paris 
and long-term unemployment has decreased by over 7 percentage points over the past decade. The young in the UK are less likely to be in temporary work but more likely to be part-time than in the OECD as a whole. Dropout rates continue to be below the OECD average. Low-paid employment is still common among youth but its persistence has halved since the early 1990s. On the other hand, a number of issues related to the labour market performance of youth the OECD note have emerged recently.

\section{c) Youth labour markets are highly cyclically volatile}

There is a considerable body of evidence suggesting that the young, the least educated and especially minorities are hardest in a recession. ${ }^{55}$ Youth unemployment rates continue to be more sensitive to business-cycle conditions than the adult unemployment rate, as many studies have shown (OECD, 2008). ${ }^{56}$ Young unskilled men from minority groups are thus particularly hard hit. This is true around the world.

Clark and Summers (1982), in their classic study of the dynamics of youth joblessness argue that the problem of teenage unemployment arises from a shortage of jobs. "Aggregate demand has a potent impact on the job prospects and market experience of teenagers" $\left(1982\right.$, p.230). ${ }^{57}$ Freeman and Wise (1982), for example, found in their study of youth joblessness in the 1970s that it was concentrated, by and large, among a small group who lacked work for extended periods of time. ${ }^{58}$ Over half of the male teenage unemployment they examined was among those who were out of work for over six months, a group constituting less than $10 \%$ of the youth labor force and only $7 \%$ of the youth population. The youths who make up the relatively small group that was chronically without work Freeman and Wise reported had distinct characteristics. They were disproportionately black; disproportionately high school dropouts, and disproportionately residents of poverty areas.

Blanchflower and Freeman (2000) identified one basic pattern in the job market for young workers: the disproportionately large response of youth employment or unemployment to changes in overall unemployment. ${ }^{59}$ They argued that the sensitivity of

\footnotetext{
55 D.G. Blanchflower and R.B. Freeman (editors), Youth Employment and Joblessness in Advanced Countries, University of Chicago Press and NBER, 2000 and Freeman, R. B. and D. A. Wise, (editors), The Youth Labor Market Problem: Its Nature, Causes, and Consequences, University of Chicago Press and NBER, 1982.

56 OECD (2008a), 'Off to a good start? Youth labour market transitions in OECD countries', $\underline{\text { OECD }}$ Employment Outlook, 2008, pp. 25-77, Paris, France.

${ }^{57}$ K.B. Clark and L.H. Summers (1982) 'The dynamics of youth unemployment' in Freeman, R. B. and D. A. Wise, (editors), The Youth Labor Market Problem: Its Nature, Causes, and Consequences, University of Chicago Press and NBER.

${ }^{58}$ Richard B. Freeman and David A. Wise (1982), 'The youth labor market problem: its nature causes and consequences:' in Freeman, R. B. and D. A. Wise, (editors), The Youth Labor Market Problem: Its Nature, Causes, and Consequences, University of Chicago Press and NBER.

${ }^{59}$ D.G. Blanchflower and R.B. Freeman (2000).
} 
youth employment and unemployment to the overall rate of unemployment dominate sizable demographic and structural changes favorable to youth in determining how youths fare in the job market. This was also confirmed in Blanchflower and Freeman (1996) and Makeham (1980). ${ }^{60}$ Recently OECD (2008a) confirmed this conclusion "Youth unemployment rates are more sensitive to business-cycle conditions than the adult unemployment rate and this high-sensitivity tends to decline progressively with age". ${ }^{61}$

There is also evidence that young people do especially well in booms. Freeman and Rodgers (1999) who analyzed the 1990s boom in the United States and found that it substantially improved the position of non-college educated young men, especially young African Americans who are the most disadvantaged and troubled group in the US. ${ }^{62}$ Young men in tight labor markets experienced a substantial boost in both employment and earnings. Adult men had no gains and their earnings barely changed even in areas where unemployment rates were below 4\%. Youths did particularly well in areas that started the boom at lower jobless rates suggesting they would "benefit especially from consistent full employment" (Freeman and Rodgers, 1999, p.2). As unemployment amongst the young goes down and the attractiveness of work increases, because there are more jobs and better paying jobs out there and it becomes a virtuous cycle. Freeman and Rodgers found evidence that once that occurred in the US the crime rate dropped. Increase aggregate demand and youths, especially disadvantaged youths, seem to do best

\section{d) Are youths pricing themselves out of jobs?}

There has been considerable interest in the possibility that youth have priced themselves out of jobs. Wells (1983) examined the relative pay and employment of young people for the period 1952-1979. During the earlier period the pay of boys to men increased from 42.0 in 1952 to 46.9 in 1969 and for girls to men it fell from 34.0 to 32.4. However, during the period 1969-1981 the boys to men ratio rose from 46.9 to 56.2 while the girls to men ratio increased from 32.5 to 40.4 . Econometric analysis confirmed the finding found that the pay and employment of young people under the age of 18 for the period 1969-81 "appears to have been reduced by increases in their relative earnings relative to

\footnotetext{
60 D.G. Blanchflower and R.B. Freeman (1996), 'Growing into Work: Youth and the Labour Market over the 1980s and 1990s', OECD Employment Outlook, OECD, Paris and P. Makeham (1980), 'Youth unemployment. An examination of evidence on youth unemployment using national statistics', Department of Employment Research Paper No. 10, London.

${ }^{61}$ OECD (2008a), 'Off to a good start? Youth labour market transitions in OECD countries', OECD Employment Outlook, OECD, Paris.

62 Freeman, R.B. and W.M. Rodgers (1999), 'Area economic conditions and the labor market outcomes of young men in the 1990s expansion', NBER Working Paper \#7073, Cambridge, MA.
} 
the average earnings of adults....No such effect could be found for the period 1952-1969" (p.1). ${ }^{63}$

Subsequently the relative earnings of youth have declined steadily. OECD (1986) found that from the 1970s through the early 1980s the earnings of youth fell relative to the earnings of adults in several countries. ${ }^{64}$ The finding that youths were overpriced relative to adults has not been replicated in subsequent periods, as youth relative wages have fallen steadily. Blanchflower and Freeman (2000) examined the relative earnings of youths aged 16-19 and 20-24 to those of adults in 11 OECD countries (Australia; Canada; Denmark; France; Germany; Italy; Japan; Norway; Sweden; the United Kingdom and the United States) and found that there were declines in the relative earnings of the young throughout the 1990s in each of these countries except Sweden, despite the fact that the size of the youth cohort was shrinking. O'Higgins (1997) also concluded that there was no close relationship between the relative wages of youth and their unemployment rates. "Indeed, the impression is that, more often than not, unemployment and relative wage rates appear to be moving in opposite directions to each other". ${ }^{65}$

The finding that the relative pay of the young has continued to decline over the last decade or so is confirmed below using data from Annual Survey of Hours and Earnings (ASHE) - previously the New Earnings Survey (NES). Gross hourly earnings of 18-21 year olds are compared to overall earnings and adults age 40-49 for the period 19972008. It is clear that the relative earnings of the young have fallen steadily since 1997 when the youth share of total unemployment started to rise.

$\begin{array}{ccc} & 18-21 / \text { total } & 18-21 / 40-49 \text { years } \\ 2008 & 51.8 \% & 45.8 \% \\ 2007 & 52.5 \% & 46.6 \% \\ 2006 & 51.3 \% & 45.3 \% \\ 2005 & 51.1 \% & 45.0 \% \\ 2004 & 52.0 \% & 46.2 \% \\ 2003 & 52.6 \% & 46.2 \% \\ 2002 & 52.8 \% & 47.6 \% \\ 2001 & 53.7 \% & 48.4 \% \\ 2000 & 53.7 \% & 47.8 \% \\ 1999 & 55.6 \% & 49.6 \% \\ 1998 & 54.6 \% & 48.5 \% \\ 1997 & 54.9 \% & 48.6 \%\end{array}$

Source: ASHE.

${ }^{63} \mathrm{~W}$. Wells (1983), 'The relative pay and employment of young people', Department of Employment Occasional Paper \# 42.

${ }^{64}$ OECD (1986), OECD Employment Outlook, OECD, Paris, France.

${ }^{65}$ N. O'Higgins (1997), 'The challenge of youth unemployment', Employment and labour market policies branch action programme on youth unemployment ', ILO, Geneva. 
http://www.statistics.gov.uk/StatBase/Product.asp?vlnk=13101\&Pos=1\&ColRank=1\&Rank=208

OECD (2008a) presented evidence on youth (20-24) earnings relative to adult earnings across countries. The evidence is presented below and suggests that a) this ratio in the UK has fallen over time and b) now is below the OECD average but was above it in 1996.

$\begin{array}{lcc} & 2006 & 1996 \\ \text { Australia } & .73 & .74 \\ \text { Canada } & .64 & .62 \\ \text { Denmark } & .65 & .72 \\ \text { Finland } & .68 & .70 \\ \text { Germany } & .61 & .62 \\ \text { Ireland } & .67 & .61 \\ \text { Japan } & .60 & .62 \\ \text { New Zealand } & .75 & .75 \\ \text { Sweden } & .68 & .73 \\ \text { UK } & .60 & .68 \\ \text { USA } & .57 & .58 \\ \text { OECD } & .64 & .67\end{array}$

Interestingly, such evidence there is that the high relative wages of the young being responsible for pricing them out of the jobs comes only from the 1970s. Interestingly, that is the period of most rapid increase in union activity. Union membership peaked in the 1970s with union density - the proportion of workers who are members of trade unions - at a little over 50\% (Lindsay, 2003). Since that time union membership numbers and density rates have fallen. In 2007 union density had fallen to $25 \%$ and $15.9 \%$ among private sector British employees. Unions generally operate rates for the job, which would have the effect of raising the relative wage of the young, and hence making them relatively less attractive, and then lowering their employment. Union membership rates among the young in the UK are especially low. Blanchflower (2007) shows, using data from the Labour Force Survey that union density rates for 16-19 year olds in 2004 were 4.3\%. In 2007 the union density rates for 16-24 year olds was 9.8\% (Mercer and Notley, 2008, Table 25). ${ }^{66}$ It does not appear that youths are pricing themselves out of work currently, unless their relative productivity is falling especially sharply, but we have no evidence to suggest that this is the case.

A further possibility is that the introduction of the National Minimum Wage, which was introduced in 1997, might have reduced employment of the young. There is little or no

\footnotetext{
${ }^{66}$ C. Lindsay (2003), 'A century of labour market change: 1900-2000', Labour Market Trends, March, pp. 133-144. S. Mercer and R. Notley (2008), Trade Union Membership, 2007, July., Department of Business, Enterprise and Regulatory Reform, http://stats.berr.gov.uk/UKSA/tu/tum2008.pdf. D.G. Blanchflower (2007), 'International patterns of union membership', British Journal of Industrial Relations, March, 45(1), pp. 1-28.
} 
evidence to sustain that claim either. ${ }^{67}$ There is a little evidence to suggest that the influx of workers, who were generally working in less skilled jobs, from the ten Accession countries did have some negative impact in the period since 2004 on the employment of the least skilled young people. ${ }^{68}$ But these effects are usually insignificant or when significant, quite small.

e) How is industrial change impacting young people's labour market prospects?

Another difficulty which will adversely affect young people's labour market prospects is the changing structure of labour demand in the UK, which reflects the substantial changes in industrial structure that have occurred in the last three decades. Autor, Levy and Murnane argue that industrial change in the USA has led to a significant change in the demand for skills. ${ }^{69}$ Rather than increased demand being entirely focused on high-skilled jobs, there has also been an increase in demand for jobs with a low skill content. In contrast, mainly as a result of changes in technology, the demand for skilled manual workers who perform routine functions and who would previously have occupied the middle of the earnings distribution, has declined dramatically. Goos and Manning(2003) produce evidence which supports this hypothesis for the UK. ${ }^{70}$ They use information from the Labour Force Survey for the period 1979-1999 and define "lousy" jobs as those occupation/industry combinations where median earnings are relatively low and "lovely" jobs as those where median earnings are relatively high. They then argue that both these types of jobs typically involve tasks that are not routine and therefore cannot be easily substituted by technology. Examples of "lousy" jobs might be care workers or gardeners, while lawyers or cell biologists could be said to work in "lovely" jobs. They then show that such non-routine jobs have exhibited the most rapid employment growth from 19791999, with the most rapidly growing occupations being care workers, software engineers and management consultants.

\footnotetext{
67 Metcalf, D. (2008), 'Why has the British National Minimum Wage had little or no impact on employment?', Journal of Industrial Relations, 50 (3), June. R. Dickens and M. Draca (2005), 'The employment effects of the October 2003 increase in the National Minimum Wage', CEP, February. Dickens, R., and Manning, A. (2003) 'Minimum Wage - Minimum Impact', in Dickens, R., Gregg, P. and Wadsworth, J. (eds.), The State of Working Britain, Palgrave McMillan, Basingstoke, pp 17-31 Report prepared for Low Pay Commission. M. Stewart (2002a) 'Estimating the impact of the minimum wage using geographical wage variation', Oxford Bulletin of Economics and Statistics, 64, pp. 583-605. M. Stewart (2002a) 'The employment effects of the National Minimum Wage', Economic Journal, 114, March, pp. C110)-C116. M. Stewart (2004), 'The impact of the introduction of the UK minimum wage on the employment probabilities of low wage workers', Journal of the European Economic Association, 2, pp. 67-97.

${ }^{68}$ Blanchflower, D.G. and C. Shadforth (2009) ibid. S. Nickell and J. Saleheen (2008), 'The impact of immigration on occupational wages: evidence from Britain', Federal Reserve Bank of Boston, Working Paper \# 08-6.

69 Autor, D. H, Levy, F. and R.J. Murnane (2003), 'The skill content of recent technological change: an empirical exploration,' Quarterly Journal of Economics, CXVIII, 1279-1333

${ }^{70}$ Goos, M. and Manning, A. (2007), 'Lousy and lovely jobs: the rising polarization of work in Britain', Review of Economics and Statistics, February, 89, pp. 118-133.
} 
To see if this process continued when the UK labour market was experiencing significant growth, we repeated the Goos and Manning exercise for the period 2002 to 2008, again using LFS data. The occupational classification used in the LFS is consistent over this period. We subdivided the 2464 occupations/industry combinations for which we had earnings data into deciles based on their median earnings in 2002. We then calculated employment in 2002 and 2008 in each of these categories and aggregated these for each of our earnings deciles. Finally, we calculated growth rates by decile using the 2002 and 2008 employment levels. We also calculated the proportion of 16-24 year olds employed in the same occupation/industry combinations and again aggregated these across the income deciles to show how far they are concentrated in "lovely" or "lousy" jobs. Figure 13 shows the results.

Most of the growth in employment between 2002 and 2008 was concentrated in jobs that would be classified as "good", because of the relatively high wages that they pay. Positive employment growth was recorded from the $7^{\text {th }}$ to the $10^{\text {th }}$ decile. Consistent with the Autor, Levy and Murnane argument, there was a significant decline in employment in those jobs around the centre of the earnings distribution. At the bottom end the picture is more mixed. A small decline in the first decile is more than offset by a large rise in employment among those in the second decile of occupation/industry combinations. The net effect is a modest increase in employment for those whose skills place them at the lower end of the earnings distribution. Thus, although, we cannot demonstrate a causal link between the decline in those occupations, where technical change has reduced employment opportunities, our evidence is consistent with both Autor and Manning.

Younger people (those aged 16-24) are predominantly associated with jobs at the lower end of this distribution. Figure 13 shows that over 20 per cent of those employed in jobs located in the lowest earnings decile are aged 16-24, while only 2.2 per cent are employed in the top ten percent of occupations. Together, these results illustrate a key difficulty for the current youth labour market. Most young people enter the labour market in fairly low-paying occupations, in which there has been a modest growth in employment. They may aspire to enhance their earnings by moving into better paying jobs. However, the "bridge" between lower-quality and better-quality jobs is disappearing in the sense that employment is falling among those jobs paying around the overall median wage. Hence the opportunities for transition are reduced. Finally, it is argued that in this new technological age the young do not possess the skills that firms need. There is less demand than in the past for unskilled jobs, particularly because of new technology and this hits the young especially hard. ${ }^{71}$ Thus, the young will face an increasingly polarised labour market. This finding has clear implications for the design of labour market interventions.

\footnotetext{
71 Berman, E., J. Bound and S. Machin (1998), 'Implications of skill-biased technological change', Quarterly Journal of Economics, 113(4), pp. 1245-1280. S. Machin and J. Van Reenen (1998), 'Technology and changes in skill structure: evidence from seven OECD countries, Quarterly Journal of Economics, 113(4), pp. 1215-1244.
} 


\section{f) Youth unemployment creates permanent scars rather than temporary blemishes}

In an important early contribution Ellwood (1982) examined the persistence and longterm impacts of early labor force experiences. The paper reports a rise in employment rates for a cohort of young men as they age, but points out that those persons with poor employment records early have comparatively poor records later. The paper found that the effects of a period without work do not end with that spell. A teenager who spends time out of work in one year will probably spend less time working in the next than he would have had he worked the entire year. Furthermore, the lost work experience Ellwood concluded were reflected in considerably lower wages. The reduced employment effects Ellwood examined appeared to die off very quickly. What appeared to persist were effects of lost work experience on wages. More recently Mroz and Savage (2006) reached a similar conclusion using data from the NLSY for the US and also found evidence of long-lived blemishes from unemployment. A six month spell of unemployment at age 22 would result in an 8 per cent lower wage at 23 and even at ages 30 and 31 wages were 2-3 per cent lower than they otherwise would have been. Kletzer and Fairlie (1999) also using data for the US estimate that for young unemployed workers the costs of job loss in terms of annual earnings are $8.4 \%$ and $13.0 \%$, for boys and girls, respectively. ${ }^{72}$

Gregg and Tominey (2005) found using data from the NCDS for the UK that there was a significant wage penalty of youth unemployment even after controlling for education, region and a wealth of family and personal characteristics. Their results suggested a scar from youth unemployment of $13-21 \%$ age 41 although this penalty was lower at $9-11 \%$ if individuals avoid repeat exposure. ${ }^{73}$ Gregg (2001) also used NCDS data to show that unemployment experience up to the age of 23 drives unemployment in subsequent years. $^{74}$

Arulampalam (2001) found that joblessness leaves permanent scars on people and reduces the probability of employment and future earnings and increases the risk of future unemployment. She found that a spell of unemployment carries a wage penalty of $6 \%$ on re-entry in Britain, and after three years, they are earning 14\% less compared to what they would have received absent unemployment. Arulampalam et al (2000) also found evidence of unemployment persistence, especially for young men. Narendranathan and Elias (1993) also find evidence of state dependence and report that 'the odds of becoming unemployed are 2.3 times higher for youths who were unemployed last year

\footnotetext{
72 T.A. Mroz and T.H. Savage (2006), 'The long-term effects of youth unemployment', Journal of Human Resources, Spring, 41(2), pp. 259-293. R. Fairlie and L.G. Kletzer (2003), 'The long-term costs of job displacement among young workers,' Industrial and Labor Relations Review, 56(4), pp. 682-698.

${ }^{73}$ P.A. Gregg and E. Tominey (2005), 'The wage scar from male youth unemployment', Labour Economics, 12, pp. 487-509

${ }^{74}$ P. Gregg (2001), 'The impact of youth unemployment on adult unemployment in NCDS', Economic Journal, 111(475), pp. F623-F653.
} 
than for youths who were not unemployed' (p.183). Arulampalam et al. (2001) also report that the best predictor of an individual's future risk of unemployment is his past history of unemployment. They find that unemployment has a scarring effect for both future unemployment and future earnings. In addition Burgess et al. (1999) find that unemployment while young raises the probability of subsequent unemployment, but the size of any effect varies by skill level. ${ }^{75}$

We now turn to examine recent evidence on youth unemployment in the UK. We find evidence that spells of youth unemployment have harmful impacts on a number of outcomes - happiness, job satisfaction, wages and health - many years later.

In order to explore the impact of unemployment while young on subsequent outcomes we examined data from the 1958 birth cohort, the National Child Development Study (NCDS). The NCDS has followed a cohort of people who were born in one week - the $3^{\text {rd }}$ to the $9^{\text {th }}$ March 1958. The National Child Development Study (NCDS) is a continuing longitudinal study that seeks to follow the lives of all those living in Great Britain who were born in one particular week in 1958. The NCDS has its origins in the Perinatal Mortality Survey (PMS). This study was sponsored by the National Birthday Trust Fund and designed to examine the social and obstetric factors associated with stillbirth and death in early infancy among the 17,000 children born in England, Scotland and Wales in that one week.

To date there have been seven attempts to trace all members of the birth cohort in order to monitor their physical, educational and social development. The first three sweeps were carried out by the National Children's Bureau, in 1965, when respondents were aged 7, in 1969 (NCDS1), aged 11 (NCDS2), in 1974, aged 16 (NCDS3). The fourth sweep, NCDS4, was conducted in 1981, when respondents were aged 23. The fifth sweep was carried out in 1991, when respondents were aged 33 (NCDS5). For the sixth wave, conducted in 1999-2000, when respondents were aged 41-42 (NCDS6), fieldwork was combined with the 1999-2000 wave of the 1970 Birth Cohort Study (BCS70). The seventh sweep of NCDS was conducted in 2004-2005, when respondents were aged 4647 years (NCDS7). It was conducted by telephone, and aimed to update the information gathered at NCDS6 in 1999-2000.

\footnotetext{
75 W. Arulampalam (2001), 'Is unemployment really scarring? Effects of unemployment experiences on wages', Economic Journal, (111), November, pp: F585-F606. W. Narendranathan and P. Elias (1993), 'Influences of past history on the incidence of youth unemployment: empirical findings for the UK', Oxford Bulletin of Economics and Statistics, 55, pp. 161-185. W. Arulampalam, A. Booth and M. Taylor (2000), 'Unemployment persistence', Oxford Economic Papers, 52, pp. 24-50. S. Burgess, C. Propper, H. Rees and A. Shearer (2003), 'The class of 1981: the effects of early career unemployment on subsequent unemployment experiences, Labour Economics, 10(3), June, pp. 291-309. For a useful summary of the school to work transition see S. Bradley and Nguyen, A.N. (2004), 'The school-to-work transition'. In: G. Johnes and J. Johnes (Eds.), International Handbook on the Economics of Education. Edward Elgar, Cheltenham, Glos.
} 
We have information available to us at age 23 in 1981 on 12537 respondents whether a) the respondent had ever been unemployed since the age of 16. Unemployment rates in the UK had risen from $5.4 \%$ in 1979 to $6.8 \%$ in 1980 and $9.6 \%$ in 1981 , when the UK had moved into recession. Unemployment would eventually peak at $11.4 \%$ in the spring of 1984. In the sample, $44 \%$ reported that at some time in their working lives they had been unemployed. The question is whether unemployment when young impacts outcomes later in life and whether the effect an unemployment spell when young is greater than when older.

Here we examine four outcomes in 2004/5 when the respondents were aged 46-47 years a) life satisfaction b) self-reported health status and two for workers only c) job satisfaction and d) (log of) gross weekly wages in 2004/5 in NCDS7. We also make use of data on whether the respondent was unemployed at age 33 in NCDS5 in 1991. The issue is whether a period of unemployment when young has lasting effects; it turns out that it does. We also include a unique set of controls identifying father's social class when the respondent was born (and reported in the PMS 1958) as well as '11-plus', verbal and non-verbal test scores reported at age 11 in NCDS2 in 1969 - tests at the local level called 11-plus were given a that time to determine entry to grammar school. We are also able to include an indicator variable on health at age 23 measured by the malaise score (indicating a tendency towards depression), which is highly significant. ${ }^{76}$ In addition we can include controls for marital status (5), highest qualification (7), region (8) labour force status (11) home ownership (5), registered disability and gender. In the job satisfaction equations we only include three labour force status dummies, exclude the marital status and home ownership dummies and include 58 industry dummies. In the wage equation the sample is limited to employees and hence only has a part-time employee dummy. The answer is that youth unemployment continues to hurt two decades later on all four 'middle-age' variables in contrast to unemployment when in one's early thirties. As we will see, there are permanent scars from youth unemployment.

Results are reported in Table 12. We look at the four outcomes in turn.

i) Life satisfaction. Respondents in NCDS7 were asked "On a scale from 0 to 10 , where ' 0 ' means that you are completely dissatisfied and '10' means that you are completely satisfied, what number corresponds with how satisfied or dissatisfied you are with the way life has turned out so far?" The mean life satisfaction score was 7.57 and 7.71 if the respondent had not been unemployed at age 23 or before and 7.42 if they had. Column 1 reports the results of estimating an ordered logit. Most of the results are standard; life satisfaction is higher for married people, the educated, workers, especially those who work full-time, those from higher social classes home owners and those who are not

\footnotetext{
${ }^{76}$ For a study using the NCDS Malaise scores at ages 23 and 33 see S.Y. Cheung and A. Buchanan (1997), 'Malaise scores in adulthood of children and young people who have been in care', Journal of Child Psychology and Psychiatry, 38(5), pp. 575 - 580. For an analysis of unemployment before the age of 23 and work histories of the NCDS birth cohort see P.E. Elias and D.G. Blanchflower (1989), Occupational earnings and work histories: who gets the good jobs?, Department of Employment Research Paper No. 68.
} 
disabled or sick or depressed (a low malaise score). Those currently unemployed are less happy; there are enduring effects from spells of unemployment while young, which continues to lower happiness more than two decades later. Clark et al (2001) also found, using panel data for Germany from the GSOEP that past unemployment lowers life satisfaction. ${ }^{77}$

In column 1 it is apparent that, as is consistently found in all happiness equations, the current unemployed are less happy. Also, if the individual had experienced any spell of unemployment before the age of twenty three, this lowers happiness over twenty years later at age 46. In contrast, a spell of unemployment at age 33 has no effect on current happiness. In column 2 it is notable from the significance of the interaction term between having had a spell of unemployment up to and including age 23 and present unemployment in column 2, that the impact of past unemployment on wellbeing is greatest for those currently unemployed. This contrasts with the findings of Clark et al who found that "the negative well being effect of current unemployment is weaker for those who have been unemployed more often in the past" (2001, p. 221). The main difference though is that their measure of past unemployment relates to the proportion of the preceding three years that had been spent in unemployment, whereas in Table 9 it refers it an unemployment spell over twenty years earlier.

ii) Health status. Respondents in NCDS7 were asked "Please think back over the last 12 months about how your health has been. Compared to people of your own age, would you say that your health has on the whole been' - 1=excellent; 2=good; 3=fair; 4=poor or $5=$ very poor?". Of those who had been unemployed in NCDS4 27.8\% said they were in excellent health compared with $34.3 \%$ of those who had not been unemployed. Column 3 of Table 13 estimates an ordered logit with self-reported health as the dependent variable. Once again the youth unemployment variable enters significantly and negative, whereas being unemployed at age 33 did not have a significant impact on health. The Malaise score is strongly negative also. Social status of father at birth matters for health nearly fifty years later. The currently unemployed are not less healthy than full-time employees.

iii) Job satisfaction. Workers were asked for their degree of satisfaction with their current job. Possible answers were "very dissatisfied; somewhat dissatisfied; neither; somewhat satisfied and very satisfied". Column 3 reports the results of estimating an ordered logit. Youth unemployment lowered job satisfaction whereas middle-age unemployment did not.

iv) Log of gross weekly wages. Column 5 of the table estimates a log wage equation. Past unemployment is also significantly negative. Those with more education earn more, as would be expected. High IQ score at 11 continues to raise wages two decades later.

\footnotetext{
77 A. Clark, Y. Georgellis, Y, and P. Sanfey P (2001), 'Scarring: the psychological impact of past unemployment', Economica, 68(270), pp. 221-241.
} 
People are impacted adversely, in terms of reduced wellbeing by increases in unemployment. The unemployed themselves lose their jobs but there is a much wider loss of wellbeing. High national unemployment lowers wellbeing especially of the unemployed. It turns out that spells of unemployment are especially harmful to the individual - and to society - when young people become unemployed. A spell of unemployment when young continues to have a harmful impact in later life. Youth unemployment is harmful and needs to be avoided.

Youth unemployment is especially harmful. As we noted above there is scant evidence to suggest that increases in unemployment are attributable to the introduction of the minimum wage or to the presence of temporary workers from Eastern Europe or that the young have priced themselves out of work. The onset of recession, at a time when the size of the youth cohort has temporarily increased, has made matters considerably worse as youths are especially vulnerable to movements in the business cycle. Now is the time to act. But what should we do? This is what we turn to consider now.

\section{Policies to Contain the Increase in Unemployment}

We have indicated that a significant rise in unemployment is likely during 2009 at least. This will have a large number of individual and social costs. Young workers are especially vulnerable to a rise in unemployment. So what kinds of policies might be worth considering in order to offset these costs? There is a substantial body of literature that analyses the effectiveness of labour market policies. Compared with almost any other type of economic policy, labour market policies have been subject to more rigorous scientific scrutiny. Nevertheless, care must be taken in generalizing from such studies. Their results may be specific to particular groups within the population; the long-run results may differ from the short-run; differences in institutional structures may reduce the applicability of studies to another country and the evaluations themselves rarely take account of the full general equilibrium consequences of policy intervention.

The OECD has taken a keen interest in these studies. It divides labour market policies into two types. "Passive" policies involve automatic cash payments to the unemployed or early retirement pensions paid for labour market purposes. "Active" policies, which largely evolved in response to the high levels of unemployment experienced in developed countries during the 1980 s, effectively comprise labour market interventions that are aimed at reducing unemployment and/or inactivity. Collectively, they are described as "Active Labour Market Programmes" (ALMPs).

In 2000, the average OECD country spent 2 per cent of its GDP on labour market policies. Eurostat data on total spending on labour market policies in 2005 (see Figure 14) indicates wide differences in the resources allocated to labour market policies across Europe. The Scandinavian countries, France, Germany and the Netherlands spent more than three times as much as the UK on labour market policies, measured as a share of GDP.

Nevertheless, although its overall spending is low, the UK allocates a relatively high proportion of its overall labour market spending to ALMPs. This partly reflects 
comparatively low levels of unemployment insurance in the UK, but also a view among policymakers that ALMP spending is at least partially effective. Policy evaluations, both domestic and international, have led to changes in the structure and emphasis of UK ALMPs. Thus, although many evaluations have been negative, the appropriate response may be redesign of policy rather than abandonment. This process of evaluation and redesign partly explains the evolution of ALMPs since their introduction in the early 1980s

Meager (2008) reviews the evaluation of ALMPs, particularly with respect to training policy. ${ }^{78} \mathrm{He}$ classifies policies into those aimed at either the demand or the supply side of the labour market. On the supply side, he identifies five main types of ALMP:

1. training schemes,

2. information and job broking activities,

3. information, advice and guidance,

4. sanctions and incentives,

5. subsidies to support entry into self-employment.

While on the demand side, he highlights two further types:

1. subsidies to employers to hire job-seekers,

2. job creation schemes.

Grubb and Martin (2001) define "special measures" as public training programmes, wage subsidy measures and public sector job creation. ${ }^{79}$ They argue that, "almost all evaluations show that special measures are not effective for disadvantaged youth". Similarly, Heckman et al (1999), argue that, "neither the experimental or nonexperimental literatures provide much evidence that employment and training programs improve US youths' labour market prospects" (p.2068). ${ }^{80}$ In the UK large scale programs, such as YOP and YTS, which provided large-scale subsidized employment were largely ineffectual. For example Dolton et al (1994) found that YTS actually lowered the probability of subsequent employment. Some studies such as O'Higgins (1994) have found more positive effects on employment but no significant employment effects for the disabled and ethnic minorities. Studies such as Green et al (1996), which have looked at the effect of YTS on earnings, have generally found a negative effect. ${ }^{81}$

\footnotetext{
${ }^{78}$ Meager, N. (2008), 'The role of training and skills development in Active Labour Market Policies', Institute for Employment Studies Working Paper 15.

${ }^{79}$ Grubb, D. and Martin, J. (2001) 'What works and for whom: a review of OECD countries' experiences with active labour market policies', OECD Office of Labour Market Policy Evaluation Working Paper 2001:14.

${ }^{80}$ Heckman, J.J, R.J. Lalonde and J.A. Smith (1999), 'The economics and econometrics of active labor market programs', in O. Ashenfelter and D. Card (eds.), Handbook of Labor Economics, Vol. 3a (NorthHolland, Amsterdam).
} 
The experimental impact studies of schemes operating under the Job Training programs in the USA, which were funded by the US Department of Labor at a cost of approximately $\$ 30$ million, showed that the schemes had either no impact at all - or even more worryingly, they scarred participants. The experiment found negative and statistically significant impacts on the earnings of male youth in the 18 months after random assignment and negligible impacts on the earnings of female youth (Bloom et al, 1993). Work by Heckman and Smith (1999a, 1999b) re-examined these results. ${ }^{82}$ They found that the estimates of the returns to training were sensitive to a) the set of training centers included in the evaluation b) how outliers in the earnings data are handled c) the construction of the earnings data d) control group substitution d) treatment group dropping out. Even after these adjustments they conclude that their results for youth "fit comfortably into the pattern of several decades of research that finds very limited earnings effects for the types of services offered by JTPA". There was some evidence of positive returns to adults and especially adult females. In response to these findings Congress cut funding for the youth component of JTPA from \$540 million in 1994 to only $\$ 110$ million in 1995 , a cut of over $80 \%$.

Grubb (1999) also reviews US education and training programs for disadvantaged youths. The ones that were successful embodied some combination of the following characteristics: ${ }^{83}$

i) close links with the local labour market, targeting jobs with relatively high wages, strong employment growth and opportunities for advancement;

ii) a mix of academic education, occupational skills and on-the-job training; ${ }^{81}$ Blanchflower, D.G., R. Jackman and G. Saint-Paul (1995), Some Reflections on Swedish Labor Market
Policy, Swedish Government official Reports \#39, Ministry of Labor, Stockholm, Sweden. Dolton, P., G.
Makepeace and J. Treble (1994), 'The Youth Training Scheme and the school-to-work transition', Oxford
Economic Papers, 46, pp. 629-657. N. O'Higgins (1994), 'YTS, employment and sample selection bias,
Oxford Economic Papers, 46, pp. 605-628. F. Green, M. Hoskings and S. Montgomery, (1996), 'The
effects of company training, further education and the Youth Training Scheme on the earnings of young
employees', Oxford Bulletin of Economics and Statistics, 58, pp. 469-488. Main B.G. and M.A. Shelley
(1990), 'The effectiveness of the Youth Training Scheme as a manpower policy, Economica, 57, pp. 485-
514. Begg, I.G., A.P. Blake, and B.M. Deakin (1991), 'YTS and the labour market', British Journal of
Industrial Relations, 29, pp.223-236.

82 Bloom, H., L. Orr, G. Cave, S. Bell, and F. Doolittle (1993), The National JTPA Study: Title IIA impacts on Earnings and Employment, Bethesda, MD, Abt Associates. Heckman, J.J. and J.A. Smith (1999a), 'The pre-programme earnings dip and the determinants of participation in a social programme. Implications for simple evaluation strategies', Economic Journal, July, 109, pp. 313-348. Heckman, J.J. and J.A. Smith (1999b), 'The sensitivity of experimental impact estimates: evidence from the National JTPA Study' in Youth Employment and Joblessness in Advanced Countries, edited by David G. Blanchflower and Richard B. Freeman, University of Chicago Press and NBER, Chicago, Illinois.

${ }^{83}$ Grubb, W.N. (1999), 'Lessons from education and training for youth: five precepts, in preparing youth for the 21st Century: the transition from education to the labour market', OECD, Paris. 
iii) opportunities to enter further education, to further develop skills and competencies;

iv) support services, focused on the needs of clients and their families; and

v) the programme is constantly upgraded by learning from past experience.

Nevertheless, successful programmes for the disadvantaged young are rare. Grubb and Martin (2001) conclude that, "one of the most disappointing conclusions from the evaluation literature is that almost all evaluations show that special measures are not effective for disadvantaged youths." This conclusion holds across the kinds of scheme we have already discussed and also includes wage subsidy and public sector job creation programmes.

Thus, early evaluations of the effectiveness of training interventions have been generally negative. While Auspos et al. (1999) concludes that European programs have not produced earnings gains for participants, they do argue that smaller targeted schemes aimed at disadvantaged groups are more effective in raising employment than broadbased training programmes, particularly when used in conjunction with job search interventions. ${ }^{84}$ Successful programmes tend to be costly and may be difficult to expand broadly. And some groups may benefit from universal training measures: Bergemann, and van den Berg (2006) ${ }^{85}$ argue that training programmes are more effective for women than men in Europe. This is consistent with the results of Heckman and Smith (1999a, $1999 \mathrm{~b}$ ). It may partly reflect lower female participation rates and the relative benefits of training may diminish as female participation rates approach those of males. Nevertheless, the evidence seems to suggest that subsidised training is likely to be more effective in a wider range of settings for unemployed women than youths.

For many years Sweden was viewed as having solved the problem of joblessness and economic inequality. During the 1970s and 1980s young workers fared reasonably despite sharply increasing youth relative wages. But the recession of the early 1990s proved that Sweden was not immune to substantial unemployment, nor to a major youth joblessness problem. In the 1990s youth unemployment has risen sharply, and the state has expanded youth participation in active labor market programs. This has reduced employment somewhat without solving the joblessness problem. Indeed, the increase in unemployment has been roughly proportional by age and education, implying that these programs have not altered the relative distribution of unemployment. The proportional growth of joblessness suggests that aggregate factors were more important in Sweden's

\footnotetext{
${ }^{84}$ Auspos P, Riccio J and White M (1999), 'A review of US and European literature on the microeconomic effects of labour market programmes for young people', Employment Service, Research and Development Report no 20, July 1999, Sheffield: The Employment Service.

${ }^{85}$ Bergemann, A. and van den Berg, G.J. (2006), 'Active Labor Market Policy effects for women in Europe: a survey', IZA Discussion Paper 2365
} 
joblessness than disaggregate shifts in demand for labour among different skill groups. ${ }^{86}$ Calmfors et al. summarize the Swedish experience in very negative terms. ${ }^{87}$ They argue that:

'(i) there is hardly any evidence for a positive effect on matching efficiency;

(ii) there are some indications of positive effects on labour force participation;

(iii) subsidized employment seems to cause displacement of regular employment, whereas this appears not to be the case for labour market training;

(iv) it is unclear whether or not ALMPs raise aggregate wage pressure in the economy

(v) in the 1990s, training programmes seem not to have enhanced the employment probabilities of participants, whereas some forms of subsidized employment seem to have had such effects; and

(vi) youth programmes seem to have caused substantial displacement effects at the same time as the gains for participants appear uncertain.' ( $p$ 1)

Non-experimental evaluations of US programs for the young are consistent with the results in the experimental literature. The estimated impacts usually are close to zero or even negative again. The wage outcomes for adult women are generally significant and large: for men they are often smaller and less consistently positive. ${ }^{88}$ The outcomes of other programs such as the Summer Training and Education Program (STEP) are disappointing. Analysis of the General Equivalence Diploma (GED), which is of interest in its own right because a major goal of many government training programs is certification of participants at high school GED levels, suggests that except for a tiny upper tail GED certified high school graduates earn roughly the same as high school dropouts. $^{89}$ In line with Auspos et al., there is some evidence that more narrowly focused, smaller, but much more expensive schemes such as Job Corps, have generated

86 Edin, P.A. and B. Holmlund (1999), 'The Swedish youth labor market in boom and depression', in Youth Employment and Joblessness in Advanced Countries, edited by David G. Blanchflower and Richard B. Freeman, University of Chicago Press and NBER, Chicago.

${ }^{87}$ Calmfors, L. Forslund, A. and Hemström, M. (2002), 'Does Active Labour Market Policy work? Lessons from the Swedish Experiences', Institute for International Economic Studies, Stockholm University.

${ }^{88}$ Heckman, J.J., R. LaLonde and J.A. Smith (1996), 'Experimental and non-experimental evaluation', in International Handbook of Labor Market Policy Evaluation edited by Gunter Schmid, Jacqueline O'Reilly and Klaus Schonmann, Edward Elgar, London.

89 Cameron, S. and J.J. Heckman (1993), 'The non-equivalence of high school equivalents', Journal of Labor Economics, 11(1) January, pp. 1-47. 
significant and quite high positive returns. ${ }^{90}$. This is a residential scheme in the USA in which youth are removed from their neighbourhoods to a separate camp, and which costs $\$ 20,000$ or so per participant. Interestingly, the main source of the benefits depends heavily on reductions in murder arrests which are very small in number but have a very high value assigned to them. ${ }^{91}$ The Jobstart program, which was essentially Job Corps without the residential training programs, had no effect in Manpower Demonstration Research Corporation's (MDRC) experimental evaluation (Cave and Doolittle, 1991). Impacts on the earnings of dropouts in the National Supported Work Demonstration (even more expensive) were negligible (Hollister, et al, 1984). The CETA estimates for youth reported in Bassi (1984) are negative for males and small for females. ${ }^{92}$

Similarly in Europe there seems to be little evidence that active labor market policies have had a positive impact on participants' wages. There is stronger evidence that they have had positive employment effects but there is no consensus on the question. Even if there were, it is unclear the extent to which any of the newly created jobs constitute net job creation or are offset by the displacement of non-participants (Heckman, LaLonde and Smith, 1999). "No cheap training problem has yet been found that can end the welfare problem" (Heckman, 1999). In 1996 when asked by the Economist how much training schemes in the US help their clientele Jim Heckman replied that 'zero is not a bad number' (Economist, 6th April, 1996).

The program evaluation literature makes it clear how important it is, as with medical trials of the effectiveness of new interventions and drug treatments, to have a fully representative control group to allow for 'what might have been' (see Heckman and Smith, 1999a, 1999b). Unfortunately, experimental evaluations involving humans are often imperfect. Some of the negative results appear due to details of the evaluation procedure, and the way the evaluators handled dropouts from the program, differences among sites, treatment of outliers, construction of earnings variables, and other technical decisions which could readily have gone differently. In addition, the fact that some youths in the "control sample" seek training outside of the program means that comparisons of the control and experimental group gives a downward bias to estimates of the effect of training per se (Heckman and Smith, 1999a, 1999b).

\footnotetext{
90 Marrar, C., S. Kerachsky, C. Thornton and D. Long (1982), 'Evaluation of the economic impact of the Job Corps Program: third follow-up report'. Princeton: Mathematica Policy Research.

91 Donohue, J. and Siegelman (1998), 'Allocating resources among prisons and social programs in the battle against crime', Journal of Legal Studies, 27(1), pp. 1-43.

92 Cave, G and F. Doolittle (1991), 'Assessing Jobstart: interim impacts of a program for school dropouts, New York, NY; Manpower Demonstration Research Corporation. Hollister, R., P. Kemper and R. Maynard eds. (1984), 'The National Supported Work Demonstration', Madison, WI, The University of Wisconsin Press. Bassi, L. (1984), 'Estimating the effects of training programs with non-random selection, Review of Economics and Statistics, 66(1), pp. 36-43.
} 
Even if there is evidence of positive employment effects of the European training schemes, it is unclear whether these impacts generate output increases or are offset by deadweight, substitution or displacement effects (Heckman, LaLonde and Smith, 1999; O'Higgins, 1997). Begg et al (1991) have estimated the total of the first two of these was of the order of $80 \%$; if so then O'Higgins notes, "the positive employment effects observed are almost entirely attributable to an improvement in participants' employment prospects at the expense of other mainly young people rather than through an improvement in the demand for young workers' (1997, p.57). Moreover, Auspos et al go on to caution that the contrast between the USA and Europe "should be treated with some caution because most US programmes have been evaluated by experimental methods which may be more stringent than the non-experimental methods used in Europe" (1999, p.81).

The New Deal for Young People (NDYP) was established in the UK in 1998 aimed at people aged 18 to 24 . To date, 2.05 million people have gained a job through this programme. All people aged 18-24 that have been on Job Seekers Allowance (JSA), equivalent to UI, for more than six months enter the "Gateway" in which they are given extensive advice on how to find employment. Participation is compulsory; every eligible individual who refuses to cooperate faces a loss of entitlement to benefits. If, after a further four months, they remain on JSA, they are offered one of four options: (1) fulltime education for 12 months; (2) a six-month job with a voluntary sector employer; (3) a six month job on the environmental task force or (4) subsidized employment in the private sector, with at least one day a week of training. Of the four options, full-time education is consistently the most popular with participants. Although the job subsidy typically covers 40-50 per cent of wage costs, it has rarely been taken up by more than 25 per cent of those on the programme. Since the introduction of NDYP, a range of other mandatory and voluntary New Deal programmes have been established aimed at specific client groups. Approximately three million two hundred thousand people had started on a New Deal programme up to August 2008. According to the most recent estimates for August 2008 there are approximately 75,000 people on the NDYP; 60,000 on the New Deal 25+; 73,000 on the New Deal for Lone Parents and 4,000 on the Lone Deal for Partners.

Blundell, et al (2001) performed an initial evaluation of the programme based on the contrast between those areas where the NDYP was initially piloted, the "Pathfinder" areas", and those where implementation was delayed. ${ }^{93}$ Focusing on the outflows into employment, they showed that the programme raised the probability of entering employment by around 5 per cent in the short run. Although the effects are relatively small, Van Reenen (2003) calculates that the marginal social benefit of the programme exceed its marginal social cost. Blundell et al (2004) also found that the impact of the

\footnotetext{
${ }^{93}$ Blundell , R., Dias, M.C., Meghir, C., Van Reenen, J. (2001) 'Evaluating The Employment Impact Of A Mandatory Job Search Assistance Program', Institute For Fiscal Studies, WP01/20
} 
program significantly raised transitions to employment by about 5 percentage points. ${ }^{94}$ The impact is robust to a wide variety of non-experimental estimators. However, they present some evidence that suggested that this effect may not be as large in the longer run. Dorsett (2006) found that a period of intensive job search using the Gateway was more effective than other options. Dorsett also found positive outcomes for the subsidized employment route relative to the three other NDYP paths. De Guiorgi (2005) found that the combination of job search assistance, training, wage subsidies, and job experience enhanced employability by about $4.6 \%$ and this effect lasted over different cohorts. A particular concern is that Podivinsky and Mcvicar (2007) found that the NDYP has had differential impacts on the probability of unemployment exits in different local labor markets. In areas of high unemployment, the treatment effect on exits to employment has been weaker than in low unemployment areas.

However, some recent evaluations of the New Deal have been less negative. This may reflect a continuing process of evaluation and improvement in its detailed structure and delivery. Such improvement may occur without any change in its structure at the macro level. Knight et al (2006), using the DWP longitudinal benefits dataset, find that the New Deal for Lone Parents (NDLP) increased the proportion of claimants leaving Income Support by 11 per cent after participating in the NDLP programme. ${ }^{95}$ Beale, Bloss and Thomas suggest that NDLP participants spent, on average, 64 fewer days on benefits than otherwise identical individuals who did not join the NDYP programme. ${ }^{96}$ Their results confirm that those following the employment option have the best outcomes from NDYP. Dorsett (2007) considers the impact of the Pathways to Work, which requires benefit claimants to attend work-focused interviews. ${ }^{97}$ Failure to comply with this requirement can result in benefits sanctions. Dorsett used a differences-in-differences procedure to examine the effects of the programme and found that the effect of Pathways to Work on employment evolved gradually and did not approach statistical significance for the first year. However, the effect appears to have grown such that eighteen months after the initial enquiry a positive effect of about 7 percentage points but again this was not

\footnotetext{
${ }^{94}$ R. Blundell, M. C. Dias, C. Meghir and J. Van Reenen (2004), 'Evaluating the employment impact of a mandatory job search program', Journal of the European Economic Association, June, 2(4), pp. 569-606. J.M Podivinsky and Duncan Mcvicar (2007), 'Does the impact of active labor market programs depend on the state of the labor market? the case of the UK New Deal for young people?' University of Southampton DP \#0704. R. Dorsett (2006), 'The New Deal for Young People: effects on the labour market status of young men', Labour Economics, 13(3), June, pp 405-422. G. De Giorgi (2005), 'The New Deal for Young People five years on', Fiscal Studies, 26(3), September, pp. 371-383.

${ }^{95}$ Knight, G., Speckesser, S., Smith, J., Dolton, P. and Azevedo, J.P., (2006) 'Lone Parents Work Focused Interviews/New Deal For Lone Parents: Combined Evaluation And Further Net Impacts', Department for Work and Pensions, Research Report No 368

${ }^{96}$ Beale, I., Bloss, C., and Thomas, A. , (2008) 'The Longer-Term Impact Of The New Deal For Young People', Department for Work and Pensions Working Paper No 23

${ }^{97}$ R. Dorsett (2007), 'The effect of pathways to work on labour market outcomes', National Institute Economic Review, 202, October, pp. 1-11.
} 
significantly different from zero at conventional levels of significance ( $p$-value of 5 percentage points or higher). By the time of the outcome interview, the effect was estimated to be 7.4 percentage points but with only a p-value of 9 per cent. There was no evidence of any significant effects for men, those over 50 or anyone without dependent children. It should be noted, however, that these more positive findings are based on data drawn from the relatively benign period of low unemployment between 1996 and 2007 when unemployment rates averaged 5.6 per cent: they may not carry over to a recession when jobs are scarce. In a recession when unemployment rates are much higher job placement rates from any ALMP are likely to plummet and the schemes are unlikely to provide adequate rates of return.

Riccio et al. (2008) examine the effectiveness of the Employment Retention and Advancement (ERA) demonstration. ${ }^{98}$ The ERA programme ERA's offered postemployment advisory support and financial incentives to help low-income individuals sustain employment and move forward in the labour market. Administered by Job Centre Plus, it was introduced in six regions of the UK. Focusing on lone parents, and using random assignment to the programme, Riccio et al. show that the programme results in the clients using more post-employment services and training, being more likely to work working full time, higher average earnings and reduced benefit takeup up to two years after entry into the programme. Less promising were the results from the New Deal 25+ customers making use of ERA, which is reported in Miller et al. (2008) ${ }^{99}$. Although consisting of the same elements - retention bonuses for employers, financial assistance for training while employed and access to emergency payments needed to stay in employment - randomized trials revealed only small positive effects on employment retention and reductions in benefit payments.

Since the New Deal 25+ clients are largely male and the Lone Parent clients mainly female, the difference in the effectiveness of the programmes seems to reinforce the tentative view that ALMPs are more effective in enhancing labour market outcomes for females than males. This is reflected in a number of the studies we have referenced. If correct, it may reflect differences in the male and female labour markets, in the relative gender-effectiveness of the design of the ALMPs or in the relative commitment of males and females to the programmes. This is a tentative speculation, but, if correct, suggests again the difficulties which young unqualified males may encounter during this recession.

Our main conclusions on ALMPS are as follows

\footnotetext{
${ }^{98}$ Riccio, J.A. Bewley, H., Campbell-Barr, V. Dorsett, R., Hamilton, G. Hoggart, L., Marsh, A., Miller, C., Ray, K.and Vegeris, S, (2008) 'Implementation and second-year impacts for lone parents in the UK Employment Retention and Advancement (ERA) demonstration', Department for Work and Pensions, Research Report No 489

${ }^{99}$ Miller, C., Bewley, H., Campbell-Barr, V., Dorsett, R., Hamilton, G., Hoggart, L., Homonoff, T., Marsh, A., Ray, K., Riccio, J. and Vegeris, S. (2008), 'Implementation and second-year impacts for New Deal 25 Plus customers in the UK Employment Retention and Advancement (ERA) demonstration', Department for Work and Pensions Research Report No 520
} 
- In the 1980 s and 1990 s, they were mostly ineffective

- Some programmes have improved learning from the detailed evaluations that have been carried out. These mostly show that targeting particular groups, devoting substantial resources per client and keeping the focus close to the jobs market are common characteristics of policies that appear to enhance the probability of finding employment.

- Many of the more rigorous studies of ALMP effectiveness show more favourable outcomes for females than males.

- The positive results were all observed during a period when the labour market was doing well - problems of deadweight loss - will increase when there is excess supply of labour.

- Scaling up the programmes that have been shown to work well (at least during a boom) would be very expensive in a recession.

- Therefore, ALMPs will have to be supported by other labour market policies to significantly offset the increase in unemployment that is now likely.

\section{Conclusions and Policy Recommendations}

Unemployment is rising fast: it will likely rise at an average of 100,000 a month for most of 2009 and will not peak until 2010. To counter this, the Bank of England has introduced a large monetary stimulus to the UK economy through cuts in interest rates and substantial injections of liquidity. The UK government has also introduced a $£ 20 \mathrm{bn}$ fiscal stimulus, through measures including cuts in VAT, accelerated capital spending and a new Small Business Finance Scheme. In terms of the labour market, three measures were proposed in the Pre-Budget Report. These were:

- an additional $£ 1.3$ billion to continue delivering effective support for helping the unemployed find a new job. These funds will be directed to the Jobcentre Plus system which is administered by the Department for Work and Pensions;

- a National Employment Partnership, bringing together Government and major employers to tackle rising unemployment; and

- refocusing Train to Gain to provide support in pre-redundancy situations, expanding the Rapid Response Service to target small and large scale redundancies and extending Local Employment Partnerships to focus on the short-term unemployed.

It is worth noting that at the time of the 2008 Pre-Budget Report, passive spending on the unemployed aged under 60 in 2009/10 was expected to comprise £3.3bn on Jobseeker's Allowance and $£ 6.7 \mathrm{bn}$ on Income Support. These estimates are predicated on an expected 
increase of 48 per cent in JSA clients and a fall of 5 per cent in Income Support Clients between 2008-09 and 2010-11. These implicit forecasts are perhaps based on a more optimistic view of UK labour market prospects than that which we envisage.

Existing ALMP schemes including NDYP, New Deal 25+, New Deal 50+, New Deal for Lone Parents, New Deal for Disabled People, New Deal for Partners, and the New Deal for Musicians are scheduled to continue. ${ }^{100}$ As mentioned earlier, at current levels of support their net cost is relatively low both relative to other components of government spending and in comparison with other advanced countries.

In January 2009, the UK government additionally pledged:

- To provide $£ 400 \mathrm{~m}$ to give firms that recruit people unemployed for more than six months "golden hellos" of up to $£ 2,500$. The expected cost is $£ 500 \mathrm{~m}$.

- Measures to increase apprenticeships by 35,000 and a system of internships to ensure students unable to find employment still find training.

Notwithstanding these measures, the ITEM club predicts that overall UK unemployment will reach 3.4 million in 2011, an increase of 1.6 million on its current level. And the European Union forecast is that the UK unemployment rate will reach 8.2 per cent in 2009 - equivalent to around 2.5 million unemployed later this year. Month-to-month increases in UK unemployment of 90,000 - 100,000 are consistent with both of these forecasts. So can these extremely adverse outcomes, with the negative individual and social implications that we have catalogued, be avoided? This will be a difficult task, given that, as we have described, evaluations of most of the ALMPs in recent decades have tended to provide at best lukewarm support. The programmes that tend to work are tightly targeted, devote significant resources to enhancing clients' human capital and operate close to the labour market.

Our previous analysis does not suggest that there is a great need for regional differentiation of labour market interventions, at least given the early evolution of unemployment during this recession. However, consistent with the analysis of more successful ALMP measures, labour market interventions to reduce unemployment should have a base in the local labour market. However, we are not making the case for significant expansion of existing ALMP measures on a broad scale such as in YTS or $Y O P$. As already mentioned, the evidential basis for such a course of action is not strong, at least in terms of their effects on participants. Other effects are not well researched. Further, such evidence as is available suggests that any positive impacts on participants may be diluted when unemployment is high, e.g. Podivinsky and Mcvicar (2007). This adds to our caution in proposing substantive expansion of existing ALMPs in the UK.

\footnotetext{
${ }^{100}$ For details of all these schemes, see: http://www.jobcentreplus.gov.uk/JCP/Customers/outofworkhelplookingforwork/Getting job ready/Progra mmes to get you ready/New Deal/
} 
We do, however, argue that there is a strong case for biasing intervention towards the young. We have made the case that the young (especially young males) are particularly adversely affected by recessions and also that unemployment can have a long lasting adverse effect on the life-experience of this group. It is also the case that short-term interventions to improve the skills and competencies of the young are quite consistent with longer-run government objectives. Thus, for example, the Leitch Report (2006) on skills recommended that, if Britain was to be in the upper quartile of OECD countries in respect of skills, it should by 2020 :

- achieve 95 percent levels of functional literacy and numeracy,

- exceed 90 per cent of adults qualified to at least level 2,

- boost the number of Modern Apprenticeships to 500,000 a year,

- increase the number of adults qualified to Level 4 or above to 40 per cent.

Below we present ten proposals for purposes of discussion. We have not fully worked out the costs of the various proposals or their effects on the public finances. The proposals are intended more as a shopping list of what could be done. Unemployment is about to rise sharply and this is the time for a rapid policy response targeted to the problem at hand - stimulate the economy, create jobs and help the young.

None of the responses are enough to deal with the jobs crisis that is coming. Our intention is to start a national debate on what should be done.

\section{Proposal 1. The government should undertake a substantial fiscal stimulus focused on jobs, as soon as possible.}

One way of maintaining the demand for labour is to engage in a substantial Keynesian fiscal stimulus. This fiscal stimulus should be based on a major extension of infrastructure projects, be focused on job creation with particular emphasis on the young. As William Rees-Mogg argued recently "in a depression, too much and too early is safer than too little and too late". ${ }^{101}$ Nevertheless, its size will be conditioned by the government's other spending commitments, including those in the financial sector, that have come in the wake of this recession.

However, determining an appropriate metric for any fiscal stimulus is hard. In labour market terms, bigger is likely to be better in the sense of alleviating the short-term and long-term consequences of unemployment. The Obama team recently presented its plans for a fiscal stimulus for the US economy focused on creating 3.7 million jobs. ${ }^{102}$ The plan calls for a fiscal stimulus of around $\$ 800$ billion. As we write, it appears that the final plan agreed by both houses will be around this amount. According to the OECD, US

\footnotetext{
${ }^{101}$ W. Rees-Mogg, 'Six vital lessons of the 1931 depression', The Times, December $29^{\text {th }}, 2008$.

${ }^{102}$ C. Romer and J. Bernstein (2009), 'The job impact of the American Recovery and Reinvestment Plan', January $10^{\text {th }}$.
} 
Gross Domestic Product at current prices in 2006 was $\$ 13,132.9$ billion, which amounts to around $6.1 \%$ of GDP. The expected impact of this injection on US growth largely explains why IMF projections for the US economy in 2009 are less pessimistic than those for the UK. The stimulus would comprise:

- substantial investments in infrastructure, education, health, and energy.

- Temporary programs to protect the most vulnerable from the deep recession, including the following.

- Increases in food stamps and expansions of unemployment insurance.

- State fiscal relief designed to alleviate cuts in healthcare, education, and prevent increases in state and local taxes.

- Business investment incentives.

- A middle class tax cut along the lines of the Making Work Pay tax cut that President Obama proposed during the campaign.

In a recent speech at the London School of Economics, Chairman of the Board of Governors of the US Federal Reserve Ben Bernanke supported this huge stimulus package but suggested that other steps must be taken to bolster the financial system, and to make any recovery stick. "Fiscal policy can stimulate economic activity, but a sustained recovery will also require a comprehensive plan to stabilize the financial system and restore normal flows of credit". ${ }^{103}$ Martin Feldstein (2009) in a recent paper has also suggested that, in current circumstances in the US, it is appropriate to undertake a substantial Keynesian fiscal stimulus package as it "has become clear that the current downturn is different from previous recessions and that monetary policy would not be effective in bringing us back to full employment". ${ }^{104}$ The nature of the current downturn is very similar in the UK and so are the arguments for a substantial fiscal stimulus here.

If a similar package was introduced in the UK, with a GDP in 2006 of $\$ 1,997$ billion US dollars this would translate to a fiscal stimulus of $\$ 122$ billion, which at today's exchange rate of $£ 1=\$ U S 1.40$ would translate to a package of around $£ 87$ billion pounds. Total employment in the US is five times higher than in the UK, so a 3.7 million job, stimulus package would translate to approximately 750,000 new jobs here. This number is a good starting point for discussion. To put this in perspective, this increase in employment is just under half the increase in UK unemployment_forecast by the ITEM club for 2011.

${ }^{103}$ B.S. Bernanke (2009), 'The crisis and the policy response', Stamp Lecture, London School of Economics, January 13, 2009.

${ }^{104}$ M. Feldstein (2009), 'Rethinking the role of fiscal policy', NBER Working Paper \#14684. 
For the UK, the Work Foundation has proposed a much more modest stimulus including that would cost only 1 per cent of GDP ( $£ 15$ billion). It would comprise:

- a one-off tax credit to the poorest households who are most likely to spend any additional income.

- Public works programme: the government should bring forward as many construction projects as possible, focusing on those that are labour intensive including: social housing, hospitals, schools and transport.

- Increased out-of-work benefits: a time-limited scheme to increase unemployment benefits to around 60 per cent of previous net earnings. This would help alleviate the adverse consequences that unemployment may have on the housing market.

- Support for the unemployed: expand the capacity of job search and support services (such as JobCentre Plus), tailored to the needs of local areas where possible. Quality must be maintained despite the numbers of unemployed people.

- Short-time working: incentives should be offered through a publicly funded shorttime working scheme to encourage employers to retain human capital rather than dismiss workers. The scheme would be suspended once recovery is under way.

- Regional aid: Devolve necessary funds and powers to encourage local authorities and Regional Development Agencies to invest in worklessness and skills schemes (or labour market policies) that respond to the particular challenges of the area; and to set up short-term schemes to help struggling.

These all seem very sensible suggestions, but we would perhaps be less cautious about the size of the necessary injection than the Work Foundation. We would also wish to focus particularly on the young not only for the short-term and long-term labour market benefits that we have already discussed, but also for reasons of intergenerational equity. The tax burden imposed by the current expansionary measures will extend into the medium and long-term and will therefore largely be paid by recent and new entrants into the labour market. Our first concern therefore is to invest in the human capital of the young. The UK has very low proportions of the young in post-compulsory schooling by international standards. Raising the education levels of the young should form an important part of the solution to the problem of rising unemployment.

Proposal 2. Provide large cuts in income taxes and National Insurance Contributions aimed at the low paid and the young. For the unemployed, mortgage interest payments could also be paid by the government in the form of a loan, with the proviso that it would have to be paid back eventually.

Large cuts in the basic rates of income taxes, increases in tax credits and/or in the levels of personal allowances would show up very quickly in people's disposable income. An alternative to tax allowances is to look at tax credits. Cuts in employee's national 
insurance would have a similar effect, while cuts in employers national insurance contributions would boost cash flow in companies being severely squeezed by the credit crunch. We need to raise consumer confidence and get people spending again.

With house prices continuing to fall increasing numbers of homeowners will find themselves in negative equity, particularly those on low incomes. In the current climate it may well be appropriate for the government to loan the interest payments on the mortgage to the unemployed to be repaid at a later date at some nominal interest rate. This loan could be paid directly to the lenders to ensure it is actually paid and not used for other purposes. Given the low level of interest rates the cost of doing so will be relatively low and such a proposal would relieve much distress and help to prevent foreclosures.

There are also arguments to suggest that both the level and the duration of benefits be increased in a recession when unemployment is largely involuntary. This lowers the impact of a loss of jobs that has occurred through little or no fault of the unemployed person.

\section{Proposal 3. Increase the education leaving age to eighteen starting in June $1^{\text {st }} 2009$ or as soon thereafter as is feasible.}

In 2008 Q3 there were 700,000 young people under the age of 18 who were economically active, of whom, 184,000 were unemployed. In an advanced society all of these youngsters should be in compulsory full-time education - at school, university or in jobs with significant elements of education and training such as apprenticeships. The Lisbon target is that at least 85 per cent of 22 year olds should complete the equivalent of upper secondary school by 2010 . The UK, currently achieves around 78 per cent, putting it significantly short of the target.

It is unsurprising then that the OECD (1997) shows that UK performance in improving skills after the age of 15 is significantly worse than that of other countries. In Scotland, performance on international benchmarks such as the Trends in International Maths and Science Survey (TIMSS) test is also declining for ages below $15^{105}$. Between the ages of 16 and 25, the International Adult Literacy Survey showed UK skill levels to be significantly lower than those of other European countries such as Germany and Switzerland. ${ }^{106}$ Our own analysis of the Labour Force Survey showed that, while on average, the qualifications of those aged 18-24 increased between 1993 and 2008, the proportion of this age group with no qualifications has changed little. The Economic Affairs Committee of the House of Lords recently concluded that, "Many school leavers in the UK have not acquired the minimum level of functional numeracy and literacy and

\footnotetext{
${ }^{105}$ For and analysis see http://www.scotland.gov.uk/Publications/2008/12/08150124/1

${ }^{106}$ OECD (1997), Literacy skills for the knowledge society: further results from the International Adult Literacy Survey, Table 1.6, Paris, France
} 
social skills necessary to benefit from apprenticeship training. In our view, the improvement of levels of functional skills in mathematics and English is fundamental and should be given much higher priority by schools." 107 We agree. Indeed, a general shift in the balance of school education towards science, technology, engineering and maths (STEM) subjects, where the returns to investment are higher, could also play a part in raising levels of productivity and competitiveness.

Support for the benefits of raising compulsory school leaving laws, has been provided recently by Phil Oreopoulos (2009). ${ }^{108}$ He examined the impact of changes in the US of recent changes to state school-leaving laws increasing the school leaving age to 17 and 18. He found that more restrictive laws had significant benefits in that they reduced dropout rates, increased college enrollment, and improved career outcomes and socioeconomic outcomes more generally. States that increased the school leaving age above 16 saw average years of schooling for 20-29 year olds' increase by about 0.13 years, and high school dropout rates fall by about 1.4 percentage points. Raising the age limit also increased postsecondary school attendance by about 1.5 percent, even though postsecondary school is not compulsory. Additional compulsory schooling significantly improved their early career outcomes by lowering the likelihood of being unemployed and increasing earnings, on average. These individuals were also less likely to fall below the poverty line and less likely to receive welfare.

"Taken together with the consistent previous evidence, the overall results suggest raising the school leaving age above 16 offers significant gains to earnings and employment outcomes, on average, to students that otherwise would have left sooner."

and later

"Raising the school leaving age may offer an effective and affordable means to increase education attainment among the least educated and improve their subsequent employment circumstances and earnings potential".

There is other evidence from the US suggesting that high school dropouts gain, on average, from staying on at school using data from historical changes in compulsory school laws. Previous studies have found that individuals compelled to stay in school also experience large gains to adult social-economic outcomes. For the United States, Angrist and Krueger (1991) and Acemoglu and Angrist (2001) estimated (using very

\footnotetext{
${ }^{107}$ House of Lords (2007), Apprenticeship: a key route to skill, Select Committee on Economic Affairs, 5th Report of Session 2006-07.

108 Oreopoulos, P. (2009), 'Would more compulsory schooling help disadvantaged youth? Evidence from recent changes to school-leaving laws?', forthcoming in An Economic Perspective on the Problems of Disadvantaged Youth, edited by Jonathan Gruber, University of Chicago Press and NBER.
} 
different methodologies) that annual adult earnings are about 10 percent higher for students compelled to stay a year longer in school.

For the UK, Harmon and Walker (1995) found about 14 percent higher earnings from school compulsion. Oreopoulos (2009) examined changes in minimum school leaving laws in England and Ireland to estimate lifetime gains to would-be dropouts from staying on. Students compelled to take an extra year of school experience an average increase of 12 percent in annual earnings. He also finds significant lifetime rewards to wealth, health, and overall happiness from having to stay in school. Lifetime wealth increases by about 10 percent with an extra year of compulsory schooling, an amount many times larger than the earnings forgone from staying the extra year. And for Canada, Oreopoulos (2006) found similar gains using provincial law changes between 1915 and 1970 for would-be dropouts compelled to stay in school. Other studies have found that additional high school lowers the likelihood of committing crime (Lochner and Moretti, 2004), of dying young (Lleras-Muney, 2005), and lowers the chances of teen pregnancy (Black, Devereux, and Salvanes, 2005). ${ }^{109}$ Additional years of schooling raise happiness.

The way to do this is to keep sixteen and seventeen year olds in school or further education colleges. For those who wish to be in work such jobs would have to include at least two days a week in education or training at a college of further education. This could clearly be a formal apprenticeship if desired. This reform will work best if all stakeholders are involved in its design - this could include employers, government and trade unions as well as the educational establishment

A further possibility worth considering is to give students a monetary incentive to stay on at high school and obtain a qualification. The Education Maintenance Allowance (EMA) offers large financial stipends to children from low-income families for every week of high school they stay beyond the minimum leaving age. Students that receive the EMA could gain more over their lifetime than the cost of the EMA itself if the additional schooling generates reasonable returns. Hence one possibility is to increase the leaving age while continuing to make EMA payments to families with low incomes.

109 Acemoglu, D. and J. Angrist (2001), 'How large are human capital externalities? evidence from compulsory schooling laws,' NBER Macro Annual, 2001, pp. 9-59. Angrist, J. D., and A. Krueger (1991), 'Does compulsory school attendance affect schooling and earnings?,' Quarterly Journal of Economics, Vol. 106, No. 4, pp. 979, 1014, 1991. Black, S.E., P.J. Devereux, and K.G. Salvanes (2004), 'Fast times at Ridgemont High? The effect of compulsory schooling laws on teenage births,' NBER Working Paper \#10911. Oreopoulos, P. (2006), 'The compelling effects of compulsory schooling: evidence from Canada' Canadian Journal of Economics, 39(1), February 2006, pp. 22-52. Oreopoulos, P. (2009), 'Do dropouts drop out too soon? Wealth, health, and happiness from compulsory schooling,' Journal of Public Economics, forthcoming. Harmon, C. and I. Walker (1995), 'Estimates of the economic return to schooling for the United Kingdom,' American Economic Review, December, pp. 1278-86. Lleras-Muney, A. (2005), 'The relationship between education and adult mortality in the United States,' Review of Economic Studies, 72(1), pp. 189-221. Lochner, L., and E. Moretti (2004), 'The effect of education on crime: evidence from prison inmates, arrests, and self-reports,' American Economic Review, 94(1), pp. 15589. 
Suggestions by the education foundation Edge, which is an independent education foundation, focused to raising the status of practical and vocational learning seem sensible. ${ }^{110}$

- Additional training and education places will have to be created, but they have to be the right ones. That means courses, which genuinely lead to jobs, careers and further learning not paper qualifications which have no lasting value.

- More people teaching and training young people in the classroom, at college and in the workplace. The right solution will be to let people from industry become teachers, either part-time or full-time, with the minimum of fuss and red tape.

- Young people need much better information, advice and guidance on the realities of the labour market. Many seem to think of education as primarily a consumption good, rather than mainly an investment good. To take this idea of enhancing information flows forward, we need a campaign inspired and led by young people themselves. Let them tell us what they want to know, and how they want to access information via the internet, social networking, face-to-face or by visits or other means.

- We have to make it easier for employers to take on Apprentices, which is not going to happen just because the Government announces some extra funding. Edge argues that "We also need substantial investment in Group Apprenticeship Schemes, which take the burden of red tape and bureaucracy out of employers' hands. Without swift action, employers will think twice about employing young people in future the exact opposite of what we and the Government want".

In private communication Philip Oreopoulos has suggested that ideally, any new policy to increase the school leaving age would include initiatives to make school more attractive (e.g. wider selection of courses, more co-op, etc.) while imposing the new law but leaving a small crack open for exceptions. Examples of exceptions would be work based apprenticeships with college based training. Ideally, Oreopoulos suggests, these laws should work in the background to establish the new norms, so that no one drops out before 18 because no one else does it. It may take some initial enforcement to get to that situation though. There is obviously a delicate balancing act, he argues, between compelling students to stay until 18 without making it feel torturous on students/parents. Oreopoulos has also suggested to us that it should be required as part of the curriculum that every student goes through the post secondary school application process, even if they don't initially intend to go (perhaps as a graduation requirement). Recent work in behavioral economics suggests this could be an effective (and cheap) way of getting students to go beyond high school. Making it easier to apply and become eligible for student aid would probably have an effect (but whether one would want these students to go on depends on whether the returns to schooling are reasonably high for them - it seems they would be, at least on average). This seems to make sense.

${ }^{110}$ http://www.edge.co.uk/Pages/NewsDetail.aspx?ContainerID=599\&ContainerName=News 
To summarize: youth unemployment in the UK is high by international standards and getting worse. The situation for the young was deteriorating well before the onset of recession in 2008. Unlike most other countries in the world, youth unemployment started rising from 2004 as did the share of youth unemployment in total unemployment and the ratio of youth-to-adult rates continues to rise. Something needs to be done about this problem and quickly. An immediate solution that is in the long-run interest of skills development and ultimately economic growth in Britain would be to raise the age at which the young cease receiving education. It is better to have young people in education than in unemployment.

Proposal 4. Provide further encouragement for those in the age range 18-24 to undertake further/higher education by increasing the number of places available

Following the arguments of Goos and Manning, additional educational activity should be focused on skills and competencies that are not likely to be routinised as a result of technological change. This would require an expansion in the number and types of places offered in further and higher education. This would inevitably require more teachers and lecturers and even professors, which leads us to our next point. This would be in both higher and further education. Educational institutions might be asked to find ways of ensuring that the skills of the many baby-boomers that are due to retire from education are not lost. Temporary expansion of HE/FE provision might help ensure that this knowledge is passed on effectively.

UCAS statistics for the period from 2003 to 2007 indicate that the number of UK domiciled applicants to HE rose from 410,000 for entry in 2004 to 454,000 for entry in 2008 (see www.ucas.ac.uk/statistics). The number of accepted applicants rose from 334,000 to 365,000 . In other words, the $10.8 \%$ increase in applicants was not matched by the increase in acceptances (9.2\%). The excess demand of 100,000 from UK domiciled applicants probably underestimates significantly the potential demand for HE. Application rates from those with non managerial/non professional have not risen over this 4 year period, remaining at $46 \%$ of all those with known socio-economic backgrounds.

Proposal 5. Provide further encouragement for those in the age range 18-24 to undertake further/higher education by providing financial inducements for them to do so.

While the number of 18 year olds in the UK is set to fall over the next few years, 2009/10 will be a critical period. With approximately 800,000 people attaining age 18 in the UK, the fall in student support will act as a major disincentive for applicants from low-income backgrounds. Targeted support, aimed at increasing take up of foundation degrees and $2+2$ full-time routes could be expanded via selective support mechanisms. More general types of support, encouraging Higher Education Institutions to increase their intakes whilst providing more support for those on low incomes (e.g. full grant and fees) could 
form the 'top-end' of a package designed to encourage 16-18 year olds to stay on in education as they prepare for Higher Education. These would be temporary measures.

\section{Proposal 6. Expand the numbers of teacher training places as soon as possible with an emphasis on training in further education}

There is growing interest in teaching as a career. The number of people inquiring about becoming a teacher has risen by almost 34 per cent since the start of the credit crunch, according to new online figures from the Training and Development Agency for Schools (TDA). From March to September 2007 the www.teach.gov.uk website received just over 758,308 unique web hits, while the same period in 2008 saw 1,018,580 hits. There has also been a 13 per cent year on year increase in the number of career changers taking a further step toward the profession by registering their interest with the TDA. This interest in teaching is likely to rise as unemployment rises.

A sensible response to this growing interest in teaching would be to i) provide further monetary incentives for young graduates to train as teachers; ii) rapidly expand the number of teacher training places in the first instance; iii) expand the number of places for teacher training in vocational subjects in further education for the new cohort of 16-17 years olds who will be encouraged to stay on at school. One advantage of this strategy is that it would put in place a new cohort of teachers before the large number of teachers in the "baby boomer" cohort retires. During the 2008/9 academic year in England, for example, there are approximately 37,000 individuals in initial teacher training $(17,500$ primary and 19,500 secondary). It would be especially appropriate to have a significant expansion of training for teachers in further education.

A further possibility would to be to create a programme of teaching internships where the unemployed with a degree can volunteer to work in schools for a year on a half salary and receive teacher training certification at the end. They could act as teacher's aids and help to reduce class sizes.

\section{Proposal 7. Do direct job creation through increased investment in the infrastructure with particular emphasis on 'shovel ready' projects that could start quickly.}

Local authorities, health authorities, universities, housing associations and others have construction projects ready to go if they had money available. Allowing these projects to start would create private sector construction jobs and much needed infusions of money into the local economies. This would be an opportunity to build a large number of social houses. It is essential that the planning system does not obstruct such initiatives. Close attention needs to be paid to the resourcing of local authority planning departments and to the extent to which legal barriers impede development.

It would be appropriate that these infrastructure projects could have a concentration on green projects, the development of clean and renewable energy, the renewal of the National Grid and the upgrading of broadband networks. Recent research by Robert Pollin and Jeannette Wicks-Lim (http://www.peri.umass.edu/green jobs) suggests that 
investments in green energy will create jobs that generally pay well above the typical wage. Providing funds to green projects will likely create good new jobs. It may well be necessary to expedite planning processes that so often hold up major investments in infrastructure projects such as placing wind turbines. Current PFI projects that are currently under threat from a lack of public funding, following on from the financial crisis, should be guaranteed by public funds. These are presumably projects that could be implemented quickly, without need for further planning, and many are large in scale.

In addition, investment in social housing, particularly aimed at housing the UKs growing elderly population, would be a worthwhile investment. The emphasis should be on labour intensive activities that maximize the number of jobs. As we have discussed, current expenditure on such employment support programmes is very low by international standards. These jobs would require some associated training strategy.

\section{Proposal 8. Allow public sector and non-profit organizations to fill available vacancies by providing increased funding for two years}

Provide funds directly to public sector organizations such as local authorities, health authorities and universities to fill the vacancies they have currently. The idea is if the budget constraint were lifted - at least temporarily - many more teachers, police, youth workers and social workers be hired. The second stage would be to have them prepare claims for further money for short-term job creation with subsidies for the unemployed and training for the young. A further possibility is to fund public works programs which would have the added bonus of providing work for unemployed construction workers.

\section{Proposal 9. Temporary, limited and targeted expansion of ALMPs}

It would be appropriate to have some limited expansion of Active Labour Market Programmes, particularly for the young. It is important they are piloted and carefully evaluated to see if the works when unemployment is high. What works in one region may not work in another. If there is evidence that a particular programme works in a period of high unemployment, only then would it warrant further funding and increased numbers of participants.

Proposal 10. Provide incentives to encourage the use of short-time working and job sharing as alternatives to redundancy and unemployment. These might take the form of time limited tax incentives.

One possibility suggested to us by Paul Gregg in private communication, which we support, would be to temporarily reduce the 'hours rules' for tax credits. Currently, except for lone parents people have to work 30 hours to claim tax credits. His suggestion, which we think is a good one, would be to reduce this to 16 or 20 hours for two years. Some people will lower their hours of work e.g. go part-time or share their jobs, to take advantage of this and so release hours of work for others. 


\section{Conclusions}

Unemployment will certainly increase sharply over the next two years or so. Its effects on many participants in the labour market will be negative and long-lasting. While much of the remedy to the problems of the labour market lies within the product and credit markets, these alone will not prevent a substantial rise in unemployment. Hence direct interventions in the labour market will be necessary and even a very large intervention stimulus package is unlikely to be offset as much as 50 per cent of the increase in unemployment that some commentators are now forecasting. The time to act is now. 
Table 1. UK and US changes in employment ('000s)

\begin{tabular}{lcc|cc} 
& \multicolumn{2}{c|}{ United Kingdom } & \multicolumn{2}{c}{ United States } \\
& Total employment & $\begin{array}{c}\text { Tonthly } \\
\text { change }\end{array}$ & Total employment & $\begin{array}{c}\text { monthly } \\
\text { change }\end{array}$ \\
2007 January & 29,046 & -41 & 137,108 & 126 \\
2007 February & 29,059 & 13 & 137,133 & 25 \\
2007 March & 29,085 & 26 & 137,310 & 177 \\
2007 April & 29,157 & 72 & 137,356 & 46 \\
2007 May & 29,159 & 2 & 137,518 & 162 \\
2007 Jun & 29,199 & 40 & 137,625 & 107 \\
2007 July & 29,220 & 21 & 137,682 & 57 \\
2007 August & 29,272 & 52 & 137,756 & 74 \\
2007 September & 29,319 & 47 & 137,837 & 81 \\
2007 October & 29,368 & 49 & 137,977 & 140 \\
2007 November & 29,398 & 30 & 138,037 & 60 \\
2007 December & 29,454 & 56 & 138,078 & 41 \\
2008 January & 29,494 & 40 & 138,002 & -76 \\
2008 February & 29,499 & 5 & 137,919 & -83 \\
2008 March & 29,506 & 7 & 137,831 & -88 \\
2008 April & 29,541 & 35 & 137,764 & -67 \\
2008 May & 29,505 & -36 & 137,717 & -47 \\
2008 June & 29,491 & -14 & 137,617 & -100 \\
2008 July & 29,419 & -72 & 137,550 & -67 \\
2008 August & 29,407 & -12 & 137,423 & -127 \\
2008 September & 29,377 & -30 & 137,020 & -403 \\
2008 October & 29,393 & +16 & 136,700 & -320 \\
2008 November & & & 136,167 & -533
\end{tabular}

Source: ONS and Bureau of Labor Statistics (Total non-farm payrolls) 
Table 2. Growth rates of GDP in volume (based on seasonally adjusted data)

\begin{tabular}{|c|c|c|c|c|}
\hline & Q4 & Q1 & Q2 & Q3 \\
\hline & 2007 & 2008 & 2008 & 2008 \\
\hline EA15 & 0.3 & 0.7 & -0.2 & -0.2 \\
\hline EU27 & 0.4 & 0.6 & 0.0 & -0.2 \\
\hline EA16 & 0.3 & 0.7 & -0.2 & -0.2 \\
\hline \multicolumn{5}{|l|}{ EU Member States } \\
\hline United Kingdom & 0.6 & 0.4 & 0.0 & -0.6 \\
\hline Belgium & 0.4 & 0.4 & 0.3 & 0.1 \\
\hline Czech Republic & 1.2 & 1.0 & 1.0 & 0.9 \\
\hline Denmark & -0.2 & -1.2 & 0.4 & -0.4 \\
\hline Germany & 0.3 & 1.4 & -0.4 & -0.5 \\
\hline Estonia & -0.1 & -1.2 & -1.5 & -0.9 \\
\hline Ireland & -0.2 & -0.3 & -0.6 & 1.2 \\
\hline Greece & 0.6 & 0.9 & 1.1 & 0.4 \\
\hline Spain & 0.6 & 0.3 & 0.1 & -0.2 \\
\hline France & 0.4 & 0.4 & -0.3 & 0.1 \\
\hline Italy & -0.4 & 0.5 & -0.4 & -0.5 \\
\hline Cyprus & 0.9 & 1.1 & 0.9 & 0.6 \\
\hline Latvia & -0.1 & -0.6 & -2.9 & -1.2 \\
\hline Lithuania & 1.8 & -0.3 & 1.0 & 0.3 \\
\hline Luxembourg & 0.9 & 0.1 & 1.1 & : \\
\hline Hungary & 0.1 & 0.5 & 0.4 & -0.1 \\
\hline Malta & 1.2 & 0.2 & 1.0 & 0.1 \\
\hline Netherlands & 1.2 & 0.3 & 0.0 & 0.0 \\
\hline Austria & 0.6 & 0.5 & 0.3 & 0.1 \\
\hline Poland & 1.7 & 1.2 & 1.3 & 1.2 \\
\hline Portugal & 0.6 & -0.2 & 0.3 & -0.1 \\
\hline Slovenia & 0.4 & 1.9 & 0.5 & 0.7 \\
\hline Slovakia & 3.0 & 1.1 & 1.8 & 1.5 \\
\hline Finland & 0.6 & 0.2 & 0.5 & 0.1 \\
\hline Sweden & 0.4 & 0.0 & -0.1 & -0.1 \\
\hline \multicolumn{5}{|l|}{ EFTA Countries } \\
\hline Iceland & -0.4 & -1.6 & 4.7 & -3.4 \\
\hline Norway & 1.1 & 0.2 & 0.1 & -0.7 \\
\hline Switzerland & 1.0 & 0.3 & 0.3 & 0.0 \\
\hline \multicolumn{5}{|c|}{ Main economic partners } \\
\hline United States & 0.0 & 0.2 & 0.7 & -0.1 \\
\hline Japan & 0.5 & 0.6 & -1.0 & -0.5 \\
\hline
\end{tabular}

Source: Eurostat Euro Indicator 4/2009 - (08/01/2009). $2^{\text {nd }}$ estimates Q32008. 
Table 3. Unemployment duration

\section{a) ILO Unemployment}

$\begin{array}{lcrcc} & \begin{array}{c}\# \\ \text { '000s }\end{array} & <6 \text { months } & \begin{array}{c}6-12 \\ \text { months }\end{array} & \begin{array}{c}\text { over 12 } \\ \text { months }\end{array} \\ \text { Sep-Nov 2006 } & 1,675 & 1006 & 285 & 384 \\ \text { Sep-Nov 2007 } & 1,633 & 987 & 261 & 384 \\ \text { Dec-Feb 2008 } & 1,614 & 955 & 269 & 390 \\ \text { Mar-May 2008 } & 1,628 & 959 & 264 & 405 \\ \text { Jun-Aug 2008 } & 1,792 & 1078 & 274 & 440 \\ \text { Sep-Nov 2008 } & 1,923 & 1,178 & 312 & 432\end{array}$

\section{b) Claimant count}

\section{7}

November

$811 \quad 555$

December

\section{8}

January

February

March

April

May

June

July

August

September

October

November

803

552

132

125

$131 \quad 119$

December

$794 \quad 548$

130

116

793

552

557

796

572

129

111

808

131

108

821

587

130

105

840

608

103

131

101

869

635

132

100

905

666

134

139

100

941

698

993

741

144

100

151

101

1,076

812

161

103

1,154

876

172

105

Source: Labour Market First Release, December 2008, ONS Tables 9(1) and 11(1). 
Table 4. Labour market expectations, average 1985-2009 and latest estimate, January 2009

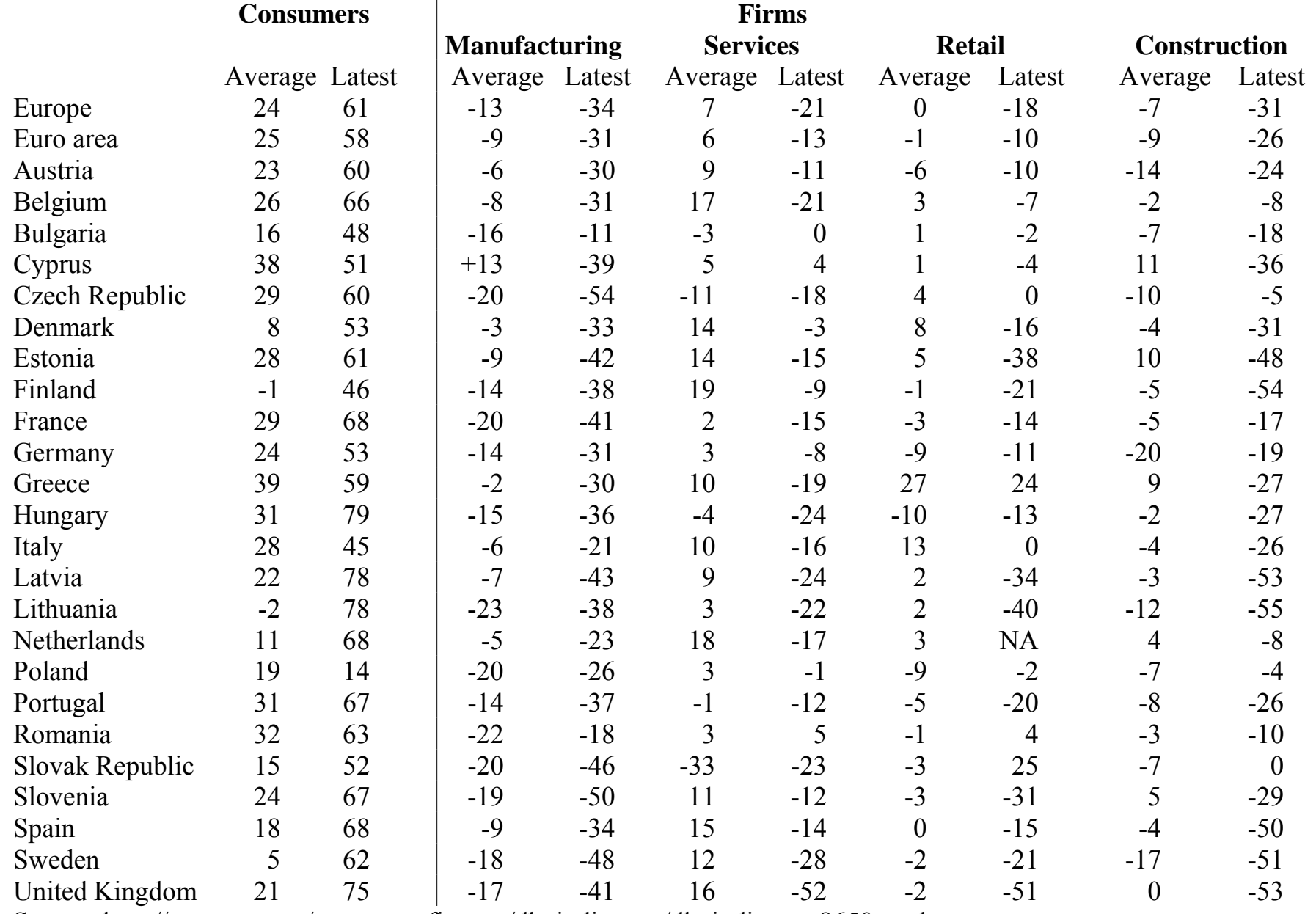

Source: http://ec.europa.eu/economy finance/db indicators/db indicators 8650 en.htm

Columns 1 and 2 relate to question 'what do you expect to happen to unemployment over the next 12 months'. Columns 3-10 relate to firms' employment expectations over the next three months by sector. 
Table 5. Employment expectations, February 2008-January 2009

\begin{tabular}{|c|c|c|c|c|c|c|c|c|c|c|c|c|}
\hline a) EU (people) & February & March & April & May & $\begin{array}{l}2008 \\
\text { June }\end{array}$ & July & August & Sept & Oct & Nov & Dec & $\begin{array}{l}2009 \\
\text { January }\end{array}$ \\
\hline i) Unemployment & 30 & 31 & 34 & 30 & 37 & 46 & 46 & 49 & 57 & 62 & 69 & 75 \\
\hline \multicolumn{13}{|l|}{ b) EU (firms) } \\
\hline i) Manufacturing & -15 & -13 & -17 & -21 & -23 & -29 & -21 & -20 & -32 & -28 & -30 & -41 \\
\hline ii) Services & 2 & 19 & 16 & 9 & 0 & 8 & -6 & -1 & -5 & -29 & -38 & -52 \\
\hline iii) Retail & -9 & -13 & -8 & -12 & -12 & -19 & -24 & -24 & -16 & -19 & -35 & -51 \\
\hline iv) Construction & 0 & -2 & -3 & -17 & -20 & -30 & -33 & -34 & -41 & -44 & -44 & -53 \\
\hline \multicolumn{13}{|l|}{ c) CIPS (firms) } \\
\hline i) Manufacturing & 51.9 & 52.3 & 51.0 & 46.5 & 47.6 & 46.6 & 47.9 & 47.3 & 45.7 & 43.1 & 40.5 & 40.2 \\
\hline ii) Services & 50.2 & 50.6 & 49.7 & 48.3 & 45.8 & 43.4 & 43.0 & 40.2 & 39.9 & 35.7 & 33.9 & 33.5 \\
\hline
\end{tabular}

\section{d) Nationwide (people)}

UK Employment Situation Current

Many/Some jobs available $\quad 53 \%$

Neither many nor few $\quad 18 \%$

Not many/few jobs available $23 \% \quad 24 \%$

Don't know

$49 \%$
$21 \%$
$24 \%$
$6 \%$

$47 \% \quad 51 \%$

$23 \% \quad 19 \%$

$25 \% \quad 24 \%$

$\begin{array}{llll}50 \% & 41 \% & 39 \% & 37 \% \\ 19 \% & 25 \% & 22 \% & 20 \% \\ 25 \% & 28 \% & 31 \% & 35 \%\end{array}$

$$
37 \%
$$

$\begin{array}{lll}30 \% & 26 \% & 23 \% \\ & \end{array}$ $6 \% \quad 7 \%$

$5 \%$

$6 \%$

$\begin{array}{rr}31 \% & 35 \% \\ 8 \% & 7 \%\end{array}$

$41 \%$

$15 \%$

$49 \%$

$12 \% \quad 12 \%$

UK Employment Situation - 6 months' time

Many/Some jobs available $\quad 39 \% \quad 38 \%$

$\begin{array}{lll}\text { Neither many or few } & 25 \% & 25 \%\end{array}$

Not many/few jobs available $31 \% \quad 31 \%$

$32 \% \quad 35 \%$

$\begin{array}{ll}32 \% & 25 \% \\ 30 \% & 31 \%\end{array}$

$37 \% \quad 28 \%$

Don't know

$6 \% \quad 6 \%$

$26 \%$

$26 \%$
$42 \%$

$\begin{array}{ll}28 \% & 25 \% \\ 21 \% & 21 \% \\ 47 \% & 48 \%\end{array}$

$22 \%$

$6 \% \quad 5 \% \quad 4 \%$

Source: Nationwide Consumer Confidence Index, January 2009; CIPS Services and |Manufacturing, January 2009 and EU http://ec.europa.eu/economy finance/db_indicators/db_indicators 8650 en.htm 
Table 6. Unemployment dprobits, 1984 and 1993 (ages 16-64)

\begin{tabular}{|c|c|c|c|c|}
\hline & & & & \\
\hline & All ages & 18-24 & All ages & $18-24$ \\
\hline Age $16-17$ & $.1552(16.71)$ & & $.1788(35.60)$ & \\
\hline Age 18-24 & $.1331(23.49)$ & & $.1196(43.51)$ & \\
\hline Age $25-29$ & $.0766(13.44)$ & & $.0505(20.01)$ & \\
\hline Age $30-34$ & $.0425(7.90)$ & & $.0308(12.65)$ & \\
\hline Age 35-39 & $.0086(1.76)$ & & $.0183(7.60)$ & \\
\hline Age $45-49$ & $-.0164(3.36)$ & & $-.0075(3.32)$ & \\
\hline Age $50-54$ & $-.0204(4.12)$ & & $.0034(1.36)$ & \\
\hline Age $55-59$ & $-.0063(1.21)$ & & $.0143(5.21)$ & \\
\hline Age $60-64$ & $-.0027(0.39)$ & & $.0029(0.91)$ & \\
\hline Male & $.0115(5.05)$ & $.0215(3.04)$ & .0437 (38.59) & $.0731(18.82)$ \\
\hline Black & $.0789(6.50)$ & $.1604(5.19)$ & $.1329(24.64)$ & $2930(14.77)$ \\
\hline Asian & $.0612(6.12)$ & $.0766(2.47)$ & $.0556(13.13)$ & $.1116(8.61)$ \\
\hline Chinese & $-.0348(1.55)$ & & $-.0158(1.53)$ & $.0627(1.49)$ \\
\hline Other race & $.0919(5.97)$ & $.2010(4.33)$ & $.0753(11.19)$ & $.1984(8.17)$ \\
\hline UK born & $-.0248(4.37)$ & $-.0386(1.90)$ & $-.0127(5.12)$ & $.0002(0.02)$ \\
\hline Higher degree & $-.0761(9.30)$ & & $-.0735(25.80)$ & $-.0669(2.73)$ \\
\hline Degree & $-.0701(16.34)$ & $-.1274(8.28)$ & $-.0686(39.83)$ & $-.1088(15.54)$ \\
\hline Other degree & $-.0664(9.04)$ & $-.1549(3.36)$ & $-.0666(22.65)$ & $-.1440(7.47)$ \\
\hline $\mathrm{HND} / \mathrm{HNC}$ & $-.0733(12.29)$ & $-.1548(7.93)$ & $-.0695(31.66)$ & $-.1444(19.49)$ \\
\hline Teacher secondary & $-.0535(5.16)$ & $.0719(0.45)$ & $-.0603(8.24)$ & $-.1112(1.16)$ \\
\hline Teacher primary & $-.0539(5.18)$ & & $-.0596(9.62)$ & $-.0644(0.94)$ \\
\hline Nursing & $-.0612(9.62)$ & $-.1402(6.76)$ & $-.0743(24.18)$ & $-.1404(9.72)$ \\
\hline $\mathrm{OND} / \mathrm{ONC}$ & $-.0656(11.56)$ & $-.1404(10.19)$ & $-.0641(25.41)$ & $-.1377(21.21)$ \\
\hline City \& Guilds & $-.0599(17.91)$ & $-.1316(13.69)$ & $-.0540(19.56)$ & $-.0958(9.97)$ \\
\hline A-level & $-.0590(14.80)$ & $-.1175(11.21)$ & $-.0564(29.12)$ & $-.1195(20.60)$ \\
\hline O-level & $-.0540(19.59)$ & $-.1327(16.40)$ & $-.0519(35.61)$ & $-.1314(24.77)$ \\
\hline CSE & $-.0319(8.06)$ & $-.0716(7.74)$ & $-.0256(11.56)$ & $-.0763(11.72)$ \\
\hline Other qualifications & $-.0173(3.52)$ & $-.0810(3.07)$ & $-.0326(16.63)$ & $-.0765(7.90)$ \\
\hline Rest of North & $-.0164(2.11)$ & $-.0303(1.20)$ & $-.0208(5.11)$ & $-.0091(0.60)$ \\
\hline South Yorkshire & $-.0153(1.82)$ & $.0071(0.25)$ & $-.0061(1.32)$ & $-.0117(0.72)$ \\
\hline West Yorkshire & $-.0404(5.77)$ & $-.0772(3.42)$ & $-.0341(8.99)$ & $-.0490(3.61)$ \\
\hline Rest Yorks \& Humber & $-.0396(5.45)$ & $-.0779(3.39)$ & $-.0338(8.33)$ & $-.0757(5.28)$ \\
\hline East Midlands & $-.0471(7.60)$ & $-.0931(4.66)$ & $-.0400(11.79)$ & $-.0582(4.69)$ \\
\hline East Anglia & $-.0570(8.75)$ & $-.1039(4.86)$ & $-.0375(10.03)$ & $-.0649(4.79)$ \\
\hline London & $-.0502(8.34)$ & $-.0993(5.17)$ & $-.0113(3.05)$ & $-.0411(3.30)$ \\
\hline Rest South East & $-.0629(10.83)$ & $-.1163(6.25)$ & $-.0377(11.26)$ & $-.0706(6.05)$ \\
\hline South West & $-.0491(7.98)$ & $-.0838(4.14)$ & $-.0357(10.41)$ & $-.0521(4.19)$ \\
\hline West Midlands & $-.0203(2.78)$ & $-.0365(1.55)$ & $-.0098(2.43)$ & $-.0291(2.11)$ \\
\hline Rest West Midlands & $-.0322(4.61)$ & $-.0666(2.98)$ & $-.0369(10.25)$ & $-.0737(5.77)$ \\
\hline Greater Manchester & $-.0225(3.08)$ & $-.0261(1.08)$ & $-.0228(5.85)$ & $-.0233(1.66)$ \\
\hline Merseyside & $.0185(2.02)$ & $.0211(0.75)$ & $.0079(1.62)$ & $.0279(1.60)$ \\
\hline Rest North West & $-.0344(4.88)$ & $-.0374(1.55)$ & $-.0371(10.07)$ & $-.0657(5.06)$ \\
\hline Wales & $-.0198(2.72)$ & $-.0279(1.17)$ & $-.0278(7.37)$ & $-.0363(2.70)$ \\
\hline Scotland & $-.0135(1.97)$ & $-.0366(1.69)$ & $-.0232(6.41)$ & $-.0369(2.84)$ \\
\hline $\mathrm{N}$ & 66,778 & 11,859 & 284,047 & 39,561 \\
\hline Pseudo $\mathrm{R}^{2}$ & .0790 & .0768 & .0704 & .0658 \\
\hline
\end{tabular}

Source: Labour Force Surveys 1984 \& 1993. Excluded categories Northern region/Tyne \& Wear; white; 40-44 \& no qualifications. In 1993 equations include a total of 31 qualifications dummies. 
Table 7. Dprobit unemployment equations, 2006-2008 (September)

\begin{tabular}{|c|c|c|c|c|c|c|}
\hline & $\begin{array}{c}2006 \\
\text { All ages }\end{array}$ & $\begin{array}{l}2007 \\
\text { All ages }\end{array}$ & $\begin{array}{c}2008 \\
\text { All ages }\end{array}$ & $\begin{array}{r}2006 \\
18-24\end{array}$ & $\begin{array}{r}2007 \\
18-24\end{array}$ & $\begin{array}{r}2008 \\
18-24\end{array}$ \\
\hline Age $16-17$ & $.1994(45.78)$ & $.2215(49.32)$ & $.2059(39.01)$ & & & \\
\hline Age $18-24$ & $.0839(37.83)$ & $.0902(39.36)$ & $.0935(34.17)$ & & & \\
\hline Age $25-29$ & $.0205(10.80)$ & $.0213(11.00)$ & $.0251(10.75)$ & & & \\
\hline Age $30-34$ & $.0090(5.21)$ & $.0134(7.39)$ & $.0134(6.10)$ & & & \\
\hline Age $35-39$ & $.0012(0.80)$ & $.0041(2.55)$ & $.0056(2.85)$ & & & \\
\hline Age $45-49$ & $-.0057(3.64)$ & $-.0044(2.78)$ & $-.0058(3.11)$ & & & \\
\hline Age $50-54$ & $-.0087(5.43)$ & $-.0077(4.74)$ & $-.0061(3.15)$ & & & \\
\hline Age $55-59$ & $-.0109(6.71)$ & $-.0034(2.05)$ & $-.0069(3.41)$ & & & \\
\hline Age $60-64$ & $-.0222(11.81$ & $-.0194(10.56)$ & $-.0184(8.53)$ & & & \\
\hline Male & $.0067(8.58)$ & $.0042(5.56)$ & $.0063(6.83)$ & $.0208(5.26)$ & $.0146(3.72)$ & $.0272(5.73)$ \\
\hline Mixed & $.0352(7.24)$ & $.0274(5.80)$ & $.0304(5.29)$ & $.0686(3.73)$ & $.0993(5.23)$ & $.0482(2.27)$ \\
\hline Asian & $.0327(13.55)$ & $.0305(13.00)$ & $.0330(11.80)$ & $.1024(9.60)$ & $1057(9.83)$ & $.0948(7.45)$ \\
\hline Black & $.0609(17.76)$ & $.0578(17.40)$ & $.0655(15.63)$ & $.1686(9.91)$ & $.1754(10.35)$ & $.1516(7.01)$ \\
\hline Chinese & $.0277(3.92)$ & $.0269(4.07)$ & $.0241(3.17)$ & $.0932(2.60)$ & $.1194(3.42)$ & $.0897(2.15)$ \\
\hline Other races & $.0463(11.33)$ & $.0427(10.94)$ & $.0418(8.88)$ & $.0692(3.52)$ & $.0721(3.73)$ & $.0526(2.39)$ \\
\hline UK born & $-.0013(0.90)$ & $-.0011(0.79)$ & $.0028(1.73)$ & $.0120(1.55)$ & $.0265(3.62)$ & $.0316(3.64)$ \\
\hline DDA disabled \& work & $.0726(35.62)$ & $.0748(36.57)$ & $.0760(30.96)$ & $.0924(8.01)$ & $.0982(7.97)$ & $.1176(8.10)$ \\
\hline DDA disabled & $.0002(0.12)$ & $.0046(2.38)$ & $.0031(1.39)$ & $.0251(1.75)$ & $-.0074(0.56)$ & $.0197(1.20)$ \\
\hline Work limiting disabled & $.0472(18.05)$ & $.0536(19.72)$ & $.0497(15.56)$ & $.0891(7.06)$ & $.1202(8.80)$ & $.0979(6.17)$ \\
\hline Higher degree & $-.0326(24.75)$ & $-.0311(24.56)$ & $-.0339(22.56)$ & $-.0938(8.57)$ & $-.0966(9.32)$ & $-.0942(7.35)$ \\
\hline NVQ level 5 & $-.0271(4.20)$ & $-.0318(5.24)$ & $-.0317(4.78)$ & $-.0979(2.97)$ & $-.1004(2.63)$ & $-.1028(2.07)$ \\
\hline First degree & $-.0331(29.95)$ & $-.0349(32.94)$ & $-.0361(28.17)$ & $-.0985(15.89)$ & $-.1047(17.95)$ & $-.0996(13.7)$ \\
\hline Other degree & $-.0329(12.56)$ & $-.0301(11.77)$ & $-.0332(9.87)$ & $-.0919(3.94)$ & $-.0996(5.63)$ & $-.1108(3.79)$ \\
\hline NVQ level 4 & $-.0294(8.90)$ & $-.0312(10.12)$ & $-.0295(8.36)$ & $-.0806(3.48)$ & & $-.1116(4.15)$ \\
\hline Diploma in HE & $-.0271(11.54)$ & $-.0274(12.64)$ & $-.0274(10.40)$ & $-.0773(5.74)$ & $-.0963(8.57)$ & $-.0945(6.37)$ \\
\hline HNC, HND, BTEC & $-.0302(19.78)$ & $-.0289(19.34)$ & $-.0326(18.25)$ & $-.0890(9.83)$ & $-.0975(11.42)$ & $-.1005(9.54)$ \\
\hline Teaching, FE & $-.0340(5.26)$ & $-.0241(4.23)$ & $-.0273(4.14)$ & & & \\
\hline Teaching, secondary & $-.0243(3.38)$ & $-.0265(3.56)$ & $-.0325(3.63)$ & & & \\
\hline Teaching, primary & $-.0329(5.05)$ & $-.0300(4.78)$ & $-.0230(3.13)$ & & & \\
\hline Teaching foundation stage & $-.0302(2.14)$ & $-.0113(0.75)$ & $-.0122(0.63)$ & & & \\
\hline Teaching, level not stated & $-.0325(3.37)$ & $-.0279(2.86)$ & $-.0233(2.08)$ & & & \\
\hline
\end{tabular}


Nursing

Other HE < degree

NVQ level 3

GNVQ/GSVQ advanced

A level or equivalent

OND, ONC, BTEC national

City \& Guilds advanced craft SCE higher

$\mathrm{A}, \mathrm{S}$ level or equivalent

Trade apprenticeship

NVQ level 2 or equivalent

GNVQ/GSVQ intermediate

City \& guilds craft/part 2

BTEC, SCOTVEC first

O level, GCSE grade A-C

NVQ level 1 or equivalent

GNVQ/GSVQ foundation

CSE below grade 1

RSA other

City \& Guilds foundation

Key skills qualification

Basic skills qualification

Other qualification

Rest of North

South Yorkshire

West Yorkshire

Rest Yorks \& Humber

East Midlands

East Anglia

Inner London

Outer London

Rest South East

South West

West Midlands

$\begin{array}{lll}-.0338(14.86) & -.0321(14.50) & -.0344(12.65) \\ -.0219(5.39) & -.0245(6.99) & -.0247(5.74) \\ -.0287(18.74) & -.0282(19.66) & -.0310(18.72) \\ -.0289(9.26) & -.0298(10.16) & -.0290(7.82) \\ -.0264(21.17) & -.0273(23.06) & -.0289(20.18) \\ -.0260(12.80) & -.0244(12.24) & -.0265(11.45) \\ -.0267(14.00) & -.0259(13.83) & -.0267(11.99) \\ -.0310(12.60) & -.0278(11.18) & -.0308(10.21) \\ -.0312(15.18) & -.0298(14.88) & -.0298(11.86) \\ -.0264(18.76) & -.0257(17.92) & -.0276(15.88) \\ -.0169(10.38) & -.0193(12.71) & -.0201(11.14) \\ -.0223(6.68) & -.0148(4.17) & -.0223(4.87) \\ -.0134(4.02) & -.0172(5.29) & -.0179(4.68) \\ -.0103(1.88) & -.0114(2.19) & -.0223(4.27) \\ -.0253(23.24) & -.0236(22.16) & -.0250(19.26) \\ .0125(2.83) & .0078(1.85) & .0043(0.86) \\ -.0101(0.93) & .0039(0.32) & .0108(0.64) \\ -.0117(6.39) & -.0110(6.09) & -.0114(5.25) \\ -.0133(2.87) & -.0255(5.41) & -.0092(1.53) \\ .0016(0.23) & .0064(0.88) & -.0024(0.29) \\ .0096(0.91) & .0076(0.71) & .0343(2.04) \\ .0197(2.41) & .0325(4.62) & .0347(4.26) \\ -.0189(13.92) & -.0198(15.26) & -.0209(13.34) \\ -.0075(2.60) & -.0042(1.37) & -.0068(1.97) \\ -.0030(0.92) & -.0030(0.89) & .0001(0.04) \\ -.0121(4.52) & -.0072(2.46) & -.0112(3.50) \\ -.0122(4.22) & -.0072(2.29) & -.0201(6.23) \\ -.0124(5.08) & -.0084(3.13) & -.0135(4.65) \\ -.0128(4.79) & -.0105(3.67) & -.0163(5.28) \\ .0045(1.43) & .0099(2.85) & -.0013(0.37) \\ -.0047(1.76) & -.0060(2.17) & -.0101(3.28) \\ -.0143(6.14) & -.0095(3.71) & -.0189(6.89) \\ -.0182(7.86) & -.0135(5.33) & -.0195(7.13) \\ -.0031(1.09) & .0044(1.36) & -.0026(0.74) \\ & & \end{array}$

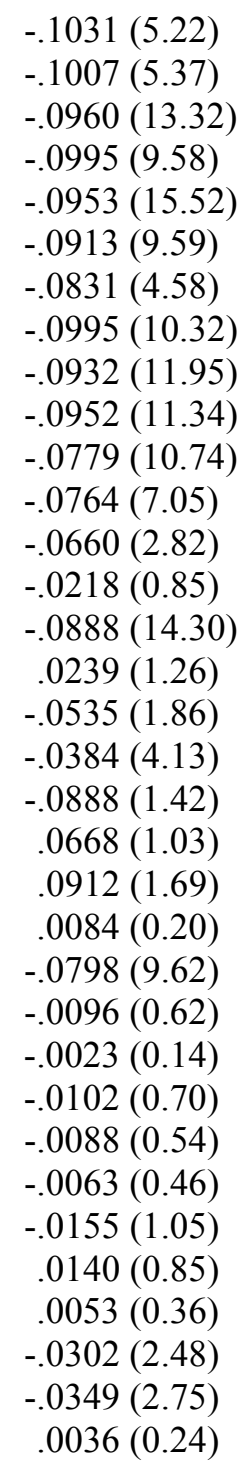

$-.1062(4.00)$ $-.0796(3.40)$

$-.1039(12.8)$

$-.1018(6.36)$

$-.1087(15.4)$

$-.0788(7.08)$

$-.0970(4.36)$

-.1058 (8.74)

$-.0914(9.76)$

$-.0995(9.94)$

$-.0838(9.73)$

$-.0859(5.20)$

$-.0723(3.54)$

$-.0691(3.50)$

$-.0794(10.7)$

$.0065(0.29)$

$-.0315(0.66)$

$-.0257(2.27)$

$-.0046(0.06)$

$.1837(2.21)$

$.2086(2.07)$

.1597 (3.65)

$-.0784(7.84)$

$-.0285(1.61)$

$.0093(0.44)$

$-.0243(1.46)$

$-.0677(4.10)$

$-.0341(2.21)$

$-.0389(2.29)$

$-.0029(0.15)$

$-.0301(1.86)$

$-.0511(3.57)$

$-.0682(4.91)$

$-.0157(0.89)$ 


\begin{tabular}{|c|c|c|c|c|c|c|}
\hline Rest West Midlands & $-.0166(6.60)$ & $-.0084(2.92)$ & $-.0165(5.49)$ & $-.0290(2.08)$ & $-.0338(2.35)$ & $-.0489(3.05)$ \\
\hline Greater Manchester & $-.0113(4.16)$ & $-.0026(0.87)$ & $-.0051(1.50)$ & $-.0268(1.91)$ & $-.0116(0.77)$ & $-.0153(0.88)$ \\
\hline Merseyside & $-.0030(0.90)$ & $.0109(2.76)$ & $.0129(2.86)$ & $.0124(0.70)$ & $.0499(2.47)$ & $.0395(1.69)$ \\
\hline Rest North West & $-.0163(6.24)$ & $-.0081(2.77)$ & $-.0143(4.53)$ & $-.0266(1.83)$ & $-.0221(1.50)$ & $-.0343(2.04)$ \\
\hline Wales & $-.0107(4.06)$ & $-.0057(1.96)$ & $-.0103(3.20)$ & $-.0115(0.81)$ & $-.0148(1.01)$ & $-.0416(2.56)$ \\
\hline Strathclyde & $-.0020(0.66)$ & $-.0029(0.92)$ & $-.0091(2.63)$ & $.0021(0.13)$ & $.0013(0.08)$ & $-.0187(0.99)$ \\
\hline Rest Scotland & $-.0110(4.09)$ & $-.0080(2.78)$ & $-.0166(5.46)$ & $.0111(0.69)$ & $.0037(0.23)$ & $-.0266(1.49)$ \\
\hline Northern Ireland & $-.0157(6.01)$ & $-.0127(4.47)$ & $-.0189(6.28)$ & $-.0456(3.41)$ & $-.0244(1.67)$ & $-.0329(1.97)$ \\
\hline February & $.0024(1.29)$ & $-.0005(0.32)$ & $-.0012(0.63)$ & $-.0022(0.24)$ & $-.0112(1.19)$ & $.0012(0.12)$ \\
\hline March & $.0002(0.16)$ & $-.0017(0.93)$ & $-.0049(2.76)$ & $-.0042(0.44)$ & $.0046(0.47)$ & $-.0084(0.87)$ \\
\hline April & $.0015(0.89)$ & $-.0030(1.76)$ & $-.0024(1.28)$ & $-.0004(0.05)$ & $-.0032(0.35)$ & $-.0102(1.02)$ \\
\hline May & $.0020(1.08)$ & $-.0036(2.00)$ & $-.0036(1.91)$ & $.0079(0.84)$ & $-.0085(0.90)$ & $-.0072(0.72)$ \\
\hline June & $.0016(0.86)$ & $-.0023(1.28)$ & $.0000(0.03)$ & $.0117(1.22)$ & $.0061(0.63)$ & $.0125(1.27)$ \\
\hline July & $.0041(2.32)$ & $-.0015(0.88)$ & $.0045(2.30)$ & $.0242(2.66)$ & $.0081(0.87)$ & $.0298(2.83)$ \\
\hline August & $.0028(1.53)$ & $-.0012(0.67)$ & $.0022(1.19)$ & $.0122(1.28)$ & $.0092(0.95)$ & $.0235(2.34)$ \\
\hline September & $.0031(1.63)$ & $-.0016(0.93)$ & $.0034(1.61)$ & $.0104(1.08)$ & $-.0082(0.90)$ & $.0208(1.81)$ \\
\hline October & $.0046(2.56)$ & $-.0031(1.71)$ & $\mathrm{n} / \mathrm{a}$ & $.0133(1.46)$ & $-.0044(0.46)$ & $\mathrm{n} / \mathrm{a}$ \\
\hline November & $.0013(0.71)$ & $-.0027(1.50)$ & $\mathrm{n} / \mathrm{a}$ & $-.0055(0.58)$ & $.0026(0.27)$ & $\mathrm{n} / \mathrm{a}$ \\
\hline December & $-.0006(0.36)$ & $-.0079(4.67)$ & $\mathrm{n} / \mathrm{a}$ & $.0017(0.19)$ & $-.0293(3.31)$ & $\mathrm{n} / \mathrm{a}$ \\
\hline $\mathrm{N}$ & 229,143 & 227,586 & 163,553 & 26,489 & 26,181 & 18,800 \\
\hline Pseudo $\mathrm{R}^{2}$ & .1191 & .1279 & .1263 & .0604 & .0716 & .0792 \\
\hline
\end{tabular}

Notes: excluded categories January; no qualifications; white: Tyne \& Wear. T-statistics in parentheses. Ages 16-64.

Source: Labour Force Surveys January 2006-September 2008. Dummies also included for International baccalaureate; RSA Diploma \& RSA Advanced Diploma, YT and YTP certificate, Scottish CSYS; SCOTVEC modules, BTEC, SCOTVEC First; Access qualifications, Don't know and entry level qualifications but results not reported but mostly insignificant. Excluded categories, Tyne \& Wear; 40-44; no qualifications; white and January. 
Table 8. EU Life satisfaction, happiness and depression ordered logits, 2005-2007

$\begin{array}{lc} & \text { Life satisfaction } \\ \text { Unemployed } & -.8266(17.47) \\ \text { Retired } & -.1645(4.25) \\ \text { Farmer } & -.3153(4.18) \\ \text { Fisherman } & -.4211(1.06) \\ \text { Professional } & .4221(5.41) \\ \text { Shop owner } & .1136(1.92) \\ \text { Business proprietor } & .4696(6.38) \\ \text { Employed professional } & .3224(5.22) \\ \text { General management } & .5665(6.29) \\ \text { Middle management } & .2726(5.82) \\ \text { Employed at a desk } & .1336(3.08) \\ \text { Employed traveling } & .0577(0.95) \\ \text { Employed in a service } & .0512(1.13) \\ \text { Supervisor } & .0364(0.37) \\ \text { Skilled manual } & -.1350(3.19) \\ \text { Unskilled manual } & -.4328(8.37) \\ \text { UK*unemployment } & -.2704(1.61) \\ \text { cut1 } & -5.7400 \\ \text { cut2 } & -3.8288 \\ \text { cut3 } & -.7126\end{array}$

Happiness
$-.2364(3.88)$
$-.0959(1.96)$
$.2954(3.08)$
$1.2834(2.13)$
$.2610(2.61)$
$.3110(4.14)$
$.3878(3.67)$
$.3852(4.70)$
$.1929(1.65)$
$.2660(4.37)$
$.1859(3.32)$
$.2497(3.17)$
$.2218(3.76)$
$-.1174(0.94)$
$.2578(4.66)$
$.0949(1.41)$
$.0565(0.26)$
-5.8636
-4.1771
-2.4559
-.0960
29,026
.0568

Down in the dumps

$$
\begin{aligned}
& .1862(3.04) \\
& .1023(2.08) \\
& -.1763(1.82) \\
& -.5877(1.00) \\
& -.1038(1.01) \\
& -.2592(3.37) \\
& -.2387(2.17) \\
& -.5861(6.54) \\
& -.6472(4.70) \\
& -.4044(6.25) \\
& -.3076(5.29) \\
& -.2414(2.93) \\
& -.2911(4.75) \\
& -.0770(0.59) \\
& -.2322(4.11) \\
& -.0869(1.29) \\
& .4423(1.99) \\
& .4231 \\
& 1.6826 \\
& 3.1893 \\
& 4.8315
\end{aligned}
$$

29,076$$
.0537
$$

Downhearted

$.2686(4.47)$

$.1704(3.52)$

$-.0893(0.96)$

$-.5430(0.93)$

$-.1106(1.11)$

$-.2336(3.15)$

$-.2644(2.50)$

$-.3804(4.62)$

$-.4818(3.89)$

$-.3254(5.26)$

$-.2026(3.64)$

$-.1715(2.18)$

$-.2322(3.96)$

$-.0266(0.22)$

$-.2733(4.96)$

$-.0217(0.33)$

$.2110(0.95)$

.2329

1.6084

3.2786

5.0002

29,069

0466

Notes: equations also include 31 country dummies; a male dummy; age and its square; 4 schooling dummies and 7 marital status dummies. T-statistics in parent heses. Excluded category 'responsible for home shopping'. Source: column 1 Eurobarometers \#67.2: European Union Enlargement, Personal Data Privacy, the National Economy, and Scientific Research, April-May 2007 \& \#68.1: The European Parliament and Media Usage, September - November, 2007 pooled and columns 2-4 Eurobarometer \#64.4: Mental Well-Being, Telecommunications, Harmful Internet Content, and Farm Animal Welfare, December 2005-January 2006. Questions. 1. On the whole, are you very satisfied, fairly satisfied, not very satisfied or not at all satisfied with the life you lead? 2. Have you felt happyall the time; most of the time: sometimes; rarely or never? 3. Have you felt so down in the dumps that nothing could cheer you up all the time; most of the time: sometimes; rarely or never? 4. Have you felt downhearted and depressed all the time; most of the time: sometimes; rarely or never? 
Table 9. Job satisfaction and job security, 2005 (ordered logits).

\begin{tabular}{|c|c|c|c|}
\hline Lose job disagree & $-.4778(15.80)$ & $-.4596(14.85)$ & $-.4612(6.64)$ \\
\hline Lose job neither & $-.7996(19.81)$ & $-.7761(18.98)$ & $-.8227(9.50)$ \\
\hline Lose job agree & $-1.1689(26.57)$ & $-1.1459(25.76)$ & $-1.2579(13.17)$ \\
\hline Lose job strongly agree & $-1.4363(25.46)$ & $-1.4292(25.18)$ & $-1.6017(13.64)$ \\
\hline Lose job DK & $-.7552(12.81)$ & $-.7349(12.30)$ & $-.8800(6.69)$ \\
\hline Lose job refuse & $-.6161(2.96)$ & $-.6040(2.90)$ & $-1.3253(2.95)$ \\
\hline Lose job disagree*UK & & $-.3858(2.68)$ & \\
\hline Lose job neither*UK & & $-.7430(2.97)$ & \\
\hline Lose job agree*UK & & $-.8243(2.83)$ & \\
\hline Age $30-49$ & $-.0042(0.13)$ & $-.0018(0.05)$ & \\
\hline Age $\geq 50$ & $.0846(2.04)$ & $.0879(2.12)$ & \\
\hline Male & $-.0930(3.51)$ & $-.0920(3.47)$ & $-.0650(1.10)$ \\
\hline Job tenure & $-.0126(3.58)$ & $-.0128(3.63)$ & $-.1015(4.52)$ \\
\hline Job tenure $^{2}$ & $.0003(3.38)$ & $.0003(3.44)$ & $.0052(2.48)$ \\
\hline Self-employed employees & $.0008(0.01)$ & $.0003(0.01)$ & $.0594(0.43)$ \\
\hline Self-employed no employees & $.3115(4.65)$ & $.3132(4.67)$ & $.4346(2.01)$ \\
\hline Supervisor & $.4144(11.51)$ & $.4136(11.48)$ & $.4149(4.04)$ \\
\hline Workplace size 2-4 & $-.2140(3.51)$ & $-.2131(3.49)$ & $-.1013(0.69)$ \\
\hline Workplace size 5-9 & $-.3694(5.64)$ & $-.3695(5.63)$ & $-.3517(2.32)$ \\
\hline Workplace size $10-49$ & $-.4004(6.46)$ & $-.3988(6.43)$ & $-.3215(2.18)$ \\
\hline Workplace size 50-99 & $-.4832(6.97)$ & $-.4811(6.94)$ & $-.4757(2.88)$ \\
\hline Workplace size 100-249 & $-.4840(6.78)$ & $-.4859(6.80)$ & $-.4865(2.81)$ \\
\hline Workplace size 200-499 & $-.5943(7.33)$ & $-.5931(7.31)$ & $-.5649(2.87)$ \\
\hline Workplace size $\geq 500$ & $-.5262(7.08)$ & $-.5250(7.06)$ & $-.6609(3.60)$ \\
\hline Workplace size $\mathrm{dk}$ & $-.4895(5.89)$ & $-.4904(5.90)$ & $-.4149(2.18)$ \\
\hline Belgium & $-.2188(2.40)$ & $-.2177(2.39)$ & $-.5514(2.55)$ \\
\hline Bulgaria & $-1.0992(12.27)$ & $-1.1033(12.32)$ & $-1.2180(5.62)$ \\
\hline Croatia & $-.7722(8.26)$ & $-.7734(8.27)$ & $-.7364(3.82)$ \\
\hline Cyprus & $-.0003(0.00)$ & $-.0002(0.00)$ & $-.3568(1.38)$ \\
\hline Czech Republic & $-.5501(5.98)$ & $-.5573(6.06)$ & $-.8613(4.22)$ \\
\hline Denmark & $.3721(4.05)$ & $.3762(4.09)$ & $.2260(1.11)$ \\
\hline Estonia & $-1.0452(10.06)$ & $-1.0503(10.11)$ & $-1.0339(4.31)$ \\
\hline Finland & $-.6245(6.96)$ & $-.6229(6.95)$ & $-.8454(4.13)$ \\
\hline France & $-.7558(8.28)$ & $-.7533(8.25)$ & $-.6901(3.33)$ \\
\hline Germany & $-.2897(3.15)$ & $-.2938(3.19)$ & $-.5520(2.73)$ \\
\hline Greece & $-1.5117(16.17)$ & $-1.5117(16.17)$ & $-1.0410(4.89)$ \\
\hline Hungary & $-1.0275(11.30)$ & $-1.0310(11.33)$ & $-1.1636(5.50)$ \\
\hline Ireland & $-.2494(2.73)$ & $-.2510(2.75)$ & $-.5613(2.78)$ \\
\hline Italy & $-1.1265(12.36)$ & $-1.1271(12.37)$ & $-1.2736(6.46)$ \\
\hline Latvia & $-1.2194(13.48)$ & $-1.2245(13.53)$ & $-1.3710(6.56)$ \\
\hline Lithuania & $-1.1133(12.16)$ & $-1.1207(12.24)$ & $-1.4000(6.29)$ \\
\hline Luxembourg & $-.5685(5.40)$ & $-.5667(5.38)$ & $-.9537(3.61)$ \\
\hline Malta & $-.6353(5.99)$ & $-.6362(6.00)$ & $-.7041(3.31)$ \\
\hline Netherlands & $-.5045(5.58)$ & $-.5051(5.59)$ & $-.3407(1.45)$ \\
\hline
\end{tabular}




$\begin{array}{lccr}\text { Norway } & .0115(0.13) & .0160(0.17) & -.3116(1.47) \\ \text { Poland } & -.5661(6.14) & -.5694(6.18) & -.6608(3.30) \\ \text { Portugal } & -.4285(4.72) & -.4317(4.76) & -.5248(2.74) \\ \text { Romania } & -1.2223(13.12) & -1.2245(13.14) & -1.5374(7.40) \\ \text { Slovakia } & -.7672(8.53) & -.7722(8.59) & -.8802(4.07) \\ \text { Slovenia } & -1.0306(9.91) & -1.0323(9.92) & -.8914(3.98) \\ \text { Spain } & -.7979(8.79) & -.7973(8.78) & -1.2059(6.29) \\ \text { Sweden } & -.4264(4.70) & -.4257(4.69) & -.6693(2.80) \\ \text { Switzerland } & .0235(0.26) & .0245(0.27) & -.2177(0.97) \\ \text { Turkey } & -1.6826(17.77) & -1.6856(17.80) & -1.8777(9.39) \\ \text { UK } & .3161(3.50) & .5564(4.98) & .3099(1.55) \\ \text { cut1 } & -3.9446 & -3.9322 & -4.1484 \\ \text { cut2 } & -2.0303 & -2.0183 & -2.2988 \\ \text { cut3 } & .8919 & .9040 & .5746 \\ \mathrm{~N} & 28,425 & 28,425 & 5,601 \\ \text { Pseudo } \mathrm{R}^{2} & .0815 & .0818 & .0870\end{array}$

Source: $4^{\text {th }}$ European Working Conditions Survey, 2005. Notes: excluded categories: Austria; works alone; employee; age 15-29 and lose job strongly disagree. All equations also include 64 industry dummies. 
Table 10. Life satisfaction equations, Europe, 1973-2006.

\begin{tabular}{|c|c|c|c|c|c|}
\hline & All & All & Unemployed & Workers & OLF \\
\hline Age & $-0.0134(17.01)$ & $-.0134(17.00)$ & $-.0362(13.95)$ & $-.0145(14.32)$ & $-.0095(10.44)$ \\
\hline $\mathrm{Age}^{2}$ & $0.0001(19.29)$ & $.0001(19.26)$ & $.0004(13.73)$ & $.0001(13.68)$ & $.0001(13.48)$ \\
\hline Male & $-0.0322(10.78)$ & $-.0319(10.78)$ & $-.1491(15.64)$ & $-.0302(9.12)$ & $-.0095(2.38)$ \\
\hline 16-19 yrs schooling & $0.0863(18.22)$ & $.0861(18.34)$ & $.0541(4.70)$ & $.0643(13.03)$ & $.1014(18.40)$ \\
\hline $20+$ yrs schooling & $0.1669(27.06)$ & $.1666(27.17)$ & $.1404(10.08)$ & $.1453(22.63)$ & $.1717(22.12)$ \\
\hline Still studying & $0.1180(8.04)$ & $.1167(8.01)$ & $.2063(5.15)$ & $.0922(4.75)$ & $.1332(6.89)$ \\
\hline Married & $0.1199(20.90)$ & $.1197(20.79)$ & $.1619(11.75)$ & .1169 (19.97) & .1449 (17.67) \\
\hline Living as married & $0.0502(8.01)$ & $.0497(7.91)$ & $.0841(4.91)$ & $.0496(7.42)$ & $.0343(3.36)$ \\
\hline Divorced & $-0.1595(20.64)$ & $-.1600(20.60)$ & $-.1850(8.60)$ & $-.1357(16.76)$ & $-.1725(13.79)$ \\
\hline Separated & $-0.2064(19.57)$ & $-.2069(19.60)$ & $-.1755(5.95)$ & $-.1900(14.16)$ & $-.2504(12.72)$ \\
\hline Widowed & $-0.0859(13.60)$ & $-.0860(13.59)$ & $-.0076(0.22)$ & $-.1038(9.89)$ & $-.0589(7.29)$ \\
\hline Unemployed & $-0.3636(30.66)$ & $-.2442(8.44)$ & & & \\
\hline Home & $-0.0216(4.44)$ & $-.0218(4.47)$ & & & $.0251(4.01)$ \\
\hline Student & $0.0712(5.01)$ & $.0715(5.05)$ & & & $.1675(7.91)$ \\
\hline Retired & $-0.0407(7.26)$ & $-.0404(7.22)$ & & & \\
\hline Austria & $-0.0960(4.13)$ & $-.0944(4.07)$ & $-.2059(4.15)$ & $-.0932(3.58)$ & $-.0823(3.74)$ \\
\hline Belgium & $-0.0802(4.27)$ & $-.0802(4.27)$ & $-.0080(0.37)$ & $-.0753(3.42)$ & $-.0886(4.58)$ \\
\hline Czech Republic & $-0.3190(16.59)$ & $-.3190(16.50)$ & $-.2630(9.53)$ & $-.3615(22.04)$ & $-.2974(12.55)$ \\
\hline Denmark & $0.3229(22.15)$ & $.3234(22.17)$ & $.4192(14.58)$ & $.3423(25.03)$ & $.2886(17.47)$ \\
\hline Finland & $-0.0023(0.12)$ & $-.0019(0.10)$ & $.1757(6.15)$ & $-.0064(0.29)$ & $-.0275(1.39)$ \\
\hline France & $-0.3273(23.59)$ & $-.3278(23.62)$ & $-.2363(10.10)$ & $-.3840(23.26)$ & $-.2757(20.09)$ \\
\hline Germany & $-0.2282(19.04)$ & $-.2277(18.92)$ & $-.3502(13.49)$ & $-.2388(18.25)$ & $-.2064(15.90)$ \\
\hline Greece & $-0.4634(21.04)$ & $-.4639(21.05)$ & $-.1077(3.05)$ & $-.4510(18.76)$ & $-.4979(22.56)$ \\
\hline Hungary & $-0.6803(35.32)$ & $-.6807(35.06)$ & $-.5363(8.94)$ & $-.6670(36.06)$ & $-.7115(27.04)$ \\
\hline Ireland & $0.0506(3.41)$ & $.0516(3.51)$ & $.0262(0.91)$ & $.0408(2.67)$ & $.0491(3.19)$ \\
\hline Italy & $-0.3445(17.64)$ & $-.3447(17.66)$ & $-.2527(6.41)$ & $-.3317(16.82)$ & $-.3787(19.09)$ \\
\hline Luxembourg & $0.0416(2.57)$ & $.0460(2.88)$ & $-.1121(2.27)$ & $.0342(1.92)$ & $.0702(3.79)$ \\
\hline Netherlands & $0.1211(10.78)$ & $.1225(10.91)$ & $.1036(3.31)$ & $.1236(9.72)$ & $.1277(10.28)$ \\
\hline Norway & $0.1078(3.51)$ & $.1086(3.55)$ & $.1231(2.04)$ & $.1497(5.20)$ & $.0591(1.95)$ \\
\hline
\end{tabular}




\begin{tabular}{|c|c|c|c|c|c|}
\hline Poland & $-0.3277(11.62)$ & $-.3209(11.16)$ & $.0190(0.31)$ & $-.3094(8.72)$ & $-.4095(15.57)$ \\
\hline Portugal & $-0.4991(21.47)$ & $-.4984(21.40)$ & $-.3846(10.09)$ & $-.4706(21.03)$ & $-.5571(21.04)$ \\
\hline Slovakia & $-0.4988(17.26)$ & $-.4966(17.15)$ & $-.1586(2.52)$ & $-.5084(20.85)$ & $-.6083(13.18)$ \\
\hline Spain & $-0.1274(7.76)$ & $-.1275(7.78)$ & $.1535(4.75)$ & $-.1540(7.88)$ & $-.1578(9.25)$ \\
\hline Sweden & $0.1055(8.35)$ & $.1063(8.42)$ & $.1772(4.76)$ & $.1091(8.21)$ & .0839 (4.97) \\
\hline Unemployment rate & $-0.0110(5.84)$ & $-.0101(5.05)$ & $-.0321(8.69)$ & $-.0089(4.55)$ & $-.0079(4.17)$ \\
\hline Inflation rate & $-0.0090(5.09)$ & $-.0090(5.05)$ & $-.0275(7.65)$ & $-.0100(5.67)$ & $-.0061(3.34)$ \\
\hline $\begin{array}{l}\text { Unemployment* } \\
\text { unemployment rate }\end{array}$ & & $-.0136(3.99)$ & & & \\
\hline Constant & 3.4793 & 3.4718 & 3.8915 & 3.5211 & 3.2389 \\
\hline $\begin{array}{l}\mathrm{N} \\
\mathrm{R}^{2}\end{array}$ & $\begin{array}{c}743,397 \\
1582\end{array}$ & $\begin{array}{c}743,397 \\
1584\end{array}$ & $\begin{array}{l}43,118 \\
1285\end{array}$ & $\begin{array}{l}300,306 \\
1580\end{array}$ & $\begin{array}{l}330,594 \\
1472\end{array}$ \\
\hline
\end{tabular}

Notes: excluded categories UK; employee, left school before age 15; single. All equations include 29 year dummies. Standard errors are clustered by country and year. Unemployment rate is measured by country and year - source: OECD. T-statistics in parentheses. Source: Eurobarometer trend file (ICPSR\# 4357) plus Eurobarometers \#65.2 (2006); 64.2 (2005); 63.4 (2005); 62.0 (2004); 61.0 (2004); 60.1 (2003). For further details see Blanchflower (2007).

Sample periods covered by country in the Eurobarometers are as follows with sample sizes in parentheses $(\mathrm{n}=820,313)$.

1975-2006 - Belgium (63,799); France (65,270); Denmark (62,967); Germany $(96,353)$; Ireland $(62,585)$; Italy $(66,124)$; Luxembourg $(26,305)$; Netherlands $(63,781)$ and the UK $(71,656)$.

$1985-2006$ - Portugal $(43,690)$ and Spain $(43,430)$.

1981-2006 - Greece $(51,955)$.

1997-2006 - Austria $(20,863)$; Finland $(21,185)$ and Sweden $(21,007)$.

2004-2006 - Czech Republic (4,367); Hungary $(4,037)$; Poland $(3,885)$ and Slovakia $(4,514)$.

1990-1994 - Norway $(8,962)$. 
Table 11. Scoreboard for youth under 25 around the World and the United Kingdom, 1997, 2006 and 2007 (\%).

\begin{tabular}{|c|c|c|c|c|c|c|c|c|c|}
\hline \multirow[b]{3}{*}{ WORLD } & \multicolumn{3}{|c|}{$\begin{array}{l}\text { Youth employment/ } \\
\text { population rates }\end{array}$} & \multicolumn{3}{|c|}{$\begin{array}{l}\text { Ratios of youth-to-adult } \\
\text { unemployment rates }\end{array}$} & \multicolumn{3}{|c|}{ Youth unemployment rates } \\
\hline & 1997 & 2006 & 2007 & 1997 & 2006 & 2007 & 1997 & 2006 & 2007 \\
\hline & 49.2 & 44.7 & 44.5 & 2.6 & 2.8 & 2.8 & 10.9 & 12.2 & 11.9 \\
\hline Developed Economies \& EU & 45.1 & 44.2 & 44.6 & 2.4 & 2.4 & 2.4 & 14.8 & 13.1 & 12.4 \\
\hline Central \& South-Eastern Europe & 35.5 & 32.6 & 32.2 & 2.3 & 2.5 & 2.5 & 21.2 & 18.5 & 18.0 \\
\hline South Asia & 45.7 & 41.7 & 41.6 & 3.7 & 3.0 & 3.0 & 6.7 & 11.1 & 10.8 \\
\hline South-East Asia \& the Pacific & 51.1 & 44.3 & 44.3 & 4.4 & 5.3 & 5.0 & 9.8 & 17.1 & 15.8 \\
\hline East Asia & 64.6 & 54.2 & 53.6 & 2.8 & 2.8 & 2.8 & 7.3 & 6.8 & 6.7 \\
\hline Latin America \& the Caribbean & 47.3 & 45.9 & 45.9 & 2.6 & 2.8 & 2.8 & 14.0 & 15.0 & 14.5 \\
\hline Middle East & 27.3 & 29.2 & 29.0 & 3.2 & 3.1 & 3.1 & 23.6 & 20.4 & 20.4 \\
\hline North Africa & 28.5 & 27.2 & 26.9 & 3.2 & 3.4 & 3.4 & 25.3 & 23.7 & 23.8 \\
\hline Sub-Saharan Africa & 51.3 & 50.1 & 49.8 & 2.0 & 1.8 & 1.8 & 12.0 & 11.6 & 11.5 \\
\hline UK & 60.8 & 57.3 & 55.9 & 2.4 & 3.8 & 3.9 & 13.4 & 13.9 & 14.4 \\
\hline
\end{tabular}

Source: ILO (2008) and OECD for the UK and own calculations from the LFS for 25+ unemployment rates. 
Table 12. The impact of youth unemployment $\leq$ age 23 on adult outcomes two decades later at age 46 in 2004/5 (NCDS)

\begin{tabular}{|c|c|c|c|c|c|}
\hline & $\begin{array}{l}\text { Life satisfaction } \\
\text { Ordered logit }\end{array}$ & $\begin{array}{l}\text { Life satisfaction } \\
\text { Ordered logit }\end{array}$ & $\begin{array}{l}\text { Health status } \\
\text { Ordered logit }\end{array}$ & $\begin{array}{c}\text { Job satisfaction } \\
\text { Ordered logit }\end{array}$ & $\begin{array}{c}\text { Log weekly wage } \\
\text { OLS }\end{array}$ \\
\hline Unemployed age $\leq 23$ & $3-.1270(2.62)$ & $-.1169(2.40)$ & $-.1534(3.05)$ & $-.1965(3.65)$ & $-.0770(3.82)$ \\
\hline Unemployed age 33 & $.0440(0.31)$ & $.0620(0.44)$ & $-.0689(0.48)$ & $-.1182(0.69)$ & $-.2256(3.52)$ \\
\hline Unempd*Unemp $\leq 23$ & & $-.9090(2.17)$ & & & \\
\hline Male & $-.4474(7.94)$ & $-.4446(7.89)$ & $-.0648(1.11)$ & $-.4094(5.90)$ & $.3674(14.32)$ \\
\hline PT employee & $-.0878(1.22)$ & $-.0857(1.19)$ & $-.1152(1.54)$ & $-.0860(1.12)$ & $-.7876(29.18)$ \\
\hline FT self-employed & $.2211(2.86)$ & $.2208(2.86)$ & $-.0061(0.08)$ & $.5117(5.76)$ & \\
\hline PT self-employed & $-.2716(1.56)$ & $-.2687(1.54)$ & $.0489(0.28)$ & $.3987(2.07)$ & \\
\hline Unemployed & $-.7668(3.62)$ & $-.2938(0.97)$ & $-.8126(3.93)$ & & \\
\hline Student & $-.5316(1.24)$ & $-.5310(1.24)$ & $-.2219(0.54)$ & & \\
\hline Govt. scheme & $-.1702(0.19)$ & $-.1819(0.20)$ & $-.9344(0.86)$ & & \\
\hline Temporary sick & $.3544(0.70)$ & $.3478(0.68)$ & $-2.2099(4.13)$ & & \\
\hline Permanent sick & $1.4352(9.85)$ & $-1.4431(9.90)$ & $-3.2899(1.72)$ & & \\
\hline Home maker & $-.2506(2.15)$ & $-.2503(2.15)$ & $-.4910(4.15)$ & & \\
\hline Retired & $-.2715(0.54)$ & $-.2728(0.54)$ & $-1.7514(3.41)$ & & \\
\hline Married & $1.1321(11.66)$ & $1.1272(11.62)$ & $.1543(11.56)$ & & \\
\hline Living together & $.6872(5.83)$ & $.6888(5.84)$ & $.2507(2.07)$ & & \\
\hline Separated & $-.2207(1.32)$ & $-.2352(1.40)$ & $.2174(1.27)$ & & \\
\hline Divorced & $-.0020(0.02)$ & $-.0085(0.07)$ & $.1341(1.09)$ & & \\
\hline Widowed & $-.6509(2.34)$ & $-.6742(2.42)$ & $.2870(1.02)$ & & \\
\hline Yorks \& Humber & $.1673(1.36)$ & $.1679(1.37)$ & $-.2394(1.90)$ & $.0783(0.57)$ & $.0463(0.92)$ \\
\hline East Midlands & $.0946(0.75)$ & $.0937(0.74)$ & $-.2073(1.62)$ & $.2620(1.88)$ & $.0664(1.29)$ \\
\hline East Anglia & $-.0579(0.40)$ & $-.0600(0.42)$ & $-.1961(1.32)$ & $.0228(0.14)$ & $-.0503(0.85)$ \\
\hline South East & $.0000(0.00)$ & $.0004(0.00)$ & $-.1926(1.79)$ & $.0383(0.33)$ & $.1682(3.95)$ \\
\hline South West & $.1476(1.20)$ & $.1493(1.22)$ & $-.2075(1.65)$ & $.1825(1.35)$ & $.0460(0.92)$ \\
\hline West Midlands & $.1787(1.45)$ & $.1793(1.46)$ & $-.1990(1.59)$ & .1748 (1.29) & $.0929(1.87)$ \\
\hline North West & .0469 (0.39) & $.0486(0.40)$ & $.0191(0.15)$ & $.1047(0.78)$ & $.0203(0.41)$ \\
\hline Wales & $.1570(1.17)$ & $.1643(1.23)$ & $.0518(0.37)$ & $.4009(2.63)$ & $.0101(0.18)$ \\
\hline Scotland & $.0460(0.38)$ & $.0484(0.40)$ & $-.3379(2.70)$ & $-.0056(0.04)$ & $.0555(1.12)$ \\
\hline
\end{tabular}




\begin{tabular}{|c|c|c|c|c|c|}
\hline CSE's grade 2-5 & $-.1800(1.99)$ & $-.1854(2.05)$ & $-.0274(0.30)$ & $-.0092(0.09)$ & $.0283(0.74)$ \\
\hline GCSE A-C & $-.2520(3.08)$ & $-.2581(3.15)$ & $.1820(2.19)$ & $-.0972(1.04)$ & $.1301(3.71)$ \\
\hline AS levels (1) & $-1.1583(2.85)$ & $-1.1620(2.86)$ & $-.2951(0.72)$ & $-.2452(0.54)$ & $1545(0.99)$ \\
\hline A-levels $(>=2)$ & $-.3435(3.14)$ & $-.3482(3.18)$ & $.3449(3.02)$ & $.0799(0.64)$ & $.3549(7.60)$ \\
\hline Diploma & $-.1251(0.93)$ & $-.1263(0.94)$ & $.3107(2.22)$ & $-.1866(1.22)$ & $.3438(16.16)$ \\
\hline Degree & $-.2082(2.04)$ & $-.2145(2.10)$ & $.2620(2.48)$ & $-.1448(1.22)$ & $.5988(13.70)$ \\
\hline Higher degree & $-.0229(0.15)$ & $-.0244(0.16)$ & $.2920(1.75)$ & $.1570(0.89)$ & .72901 .14 \\
\hline House mortgage & $-.2995(4.32)$ & $-.3025(4.36)$ & $-.0116(0.16)$ & & \\
\hline Rent & $-.7285(7.11)$ & $-.7323(7.15)$ & $-.1058(1.02)$ & & \\
\hline Social class i PMS & $.2101(1.05)$ & $.2197(1.10)$ & .2459 (1.19) & $.1868(0.83)$ & $.0124(0.15)$ \\
\hline Social class ii PMS & $.1868(1.05)$ & $.1938(1.09)$ & $.0231(0.13)$ & $.0510(0.25)$ & $-.0884(1.20)$ \\
\hline Social class iii PMS & $.3132(1.86)$ & $.3198(1.90)$ & $-.0088(0.05)$ & $.2167(1.12)$ & $-.1288(1.85)$ \\
\hline Social class iv PMS & $.3237(1.81)$ & $.3308(1.85)$ & $-.1051(0.57)$ & $2440(1.19)$ & $-.1751(2.35)$ \\
\hline Social class v PMS & $.2357(1.25)$ & $.2434(1.29)$ & $-.2590(1.33)$ & $.1888(0.88)$ & $-.1417(1.82)$ \\
\hline IQ score NCDS2 & $-.0023(1.22)$ & $-.0023(1.24)$ & $.0018(0.93)$ & $-.0004(0.19)$ & $.0024(3.01)$ \\
\hline Malaise NCDS4 & $-.1250(13.39)$ & $-.1245(13.33)$ & $-.1424(15.05)$ & $-.0557(5.31)$ & $-.0148(3.78)$ \\
\hline Industry dummies & No & No & No & 58 & 58 \\
\hline cut1 & -6.4392 & -6.4424 & -5.1878 & -3.8119 & 6.0671 \\
\hline cut2 & -5.9477 & -5.9509 & -3.4554 & -2.8358 & \\
\hline cut3 & -5.2196 & -5.2224 & -1.8254 & -2.4125 & \\
\hline cut4 & -4.6091 & -4.6112 & .4221 & -.4425 & \\
\hline cut5 & -3.8722 & -3.8736 & & & \\
\hline cut6 & -2.6808 & -2.6812 & & & \\
\hline cut7 & -1.9470 & -1.9465 & & & \\
\hline cut8 & -.5206 & -.5189 & & & \\
\hline cut9 & 1.3464 & 1.3481 & & & \\
\hline cut10 & 2.6866 & 2.6884 & & & \\
\hline $\mathrm{N}$ & 6187 & 6187 & 6196 & 5503 & 3755 \\
\hline Pseudo $R^{2} / R^{2}$ & .0470 & .0472 & .0751 & .0196 & .4991 \\
\hline
\end{tabular}

Notes: excluded categories: North; no qualifications; own house outright: FT employee; no husband. Workers only columns 4 \& 5 Source: National Child Development Study, 1958-2004/5. Outcomes measured at NCDS7 
Figure 1. Unemployment rates for ten countries, 1960-2008

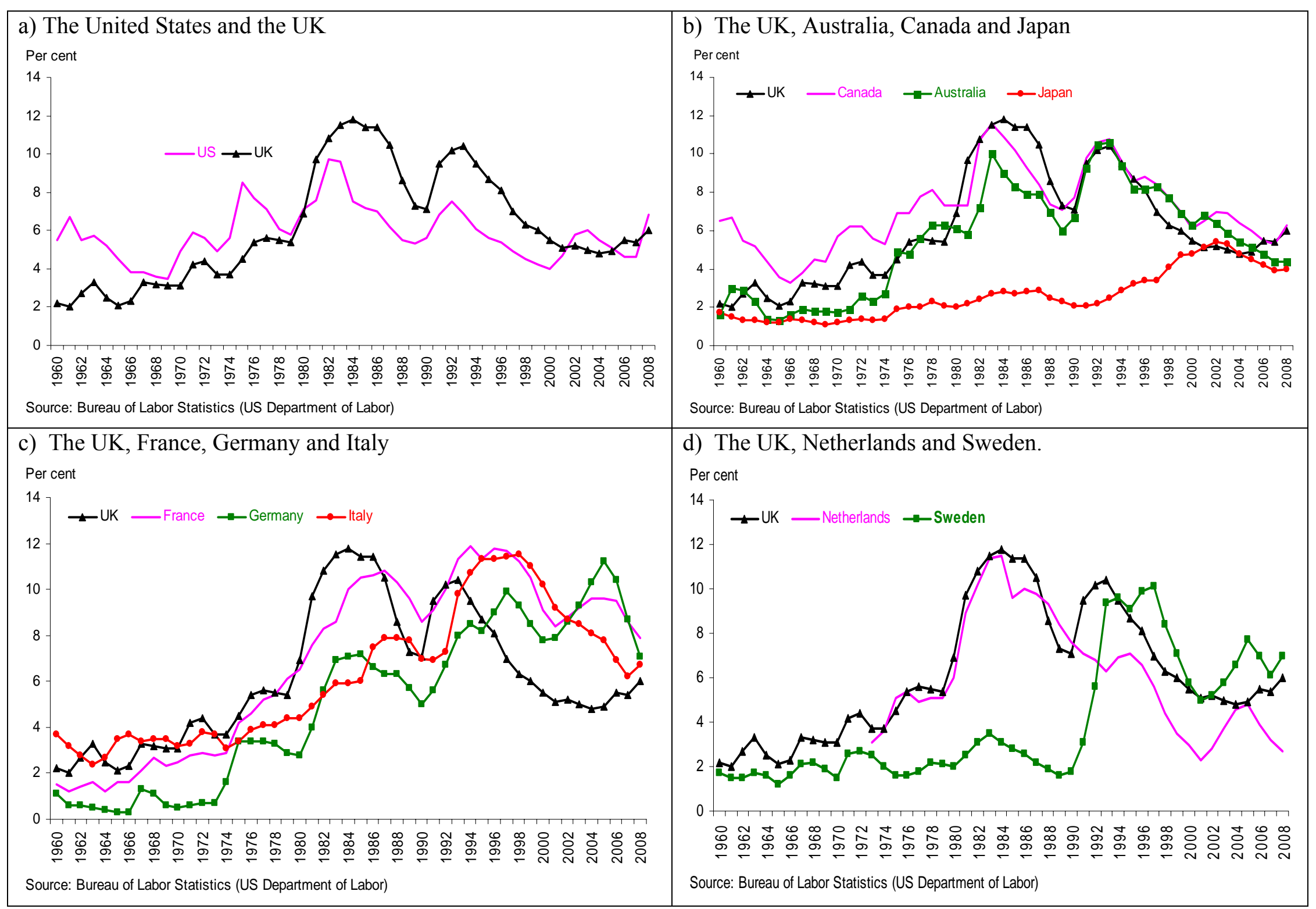


Figure 2. Youth unemployment, 1992-2008

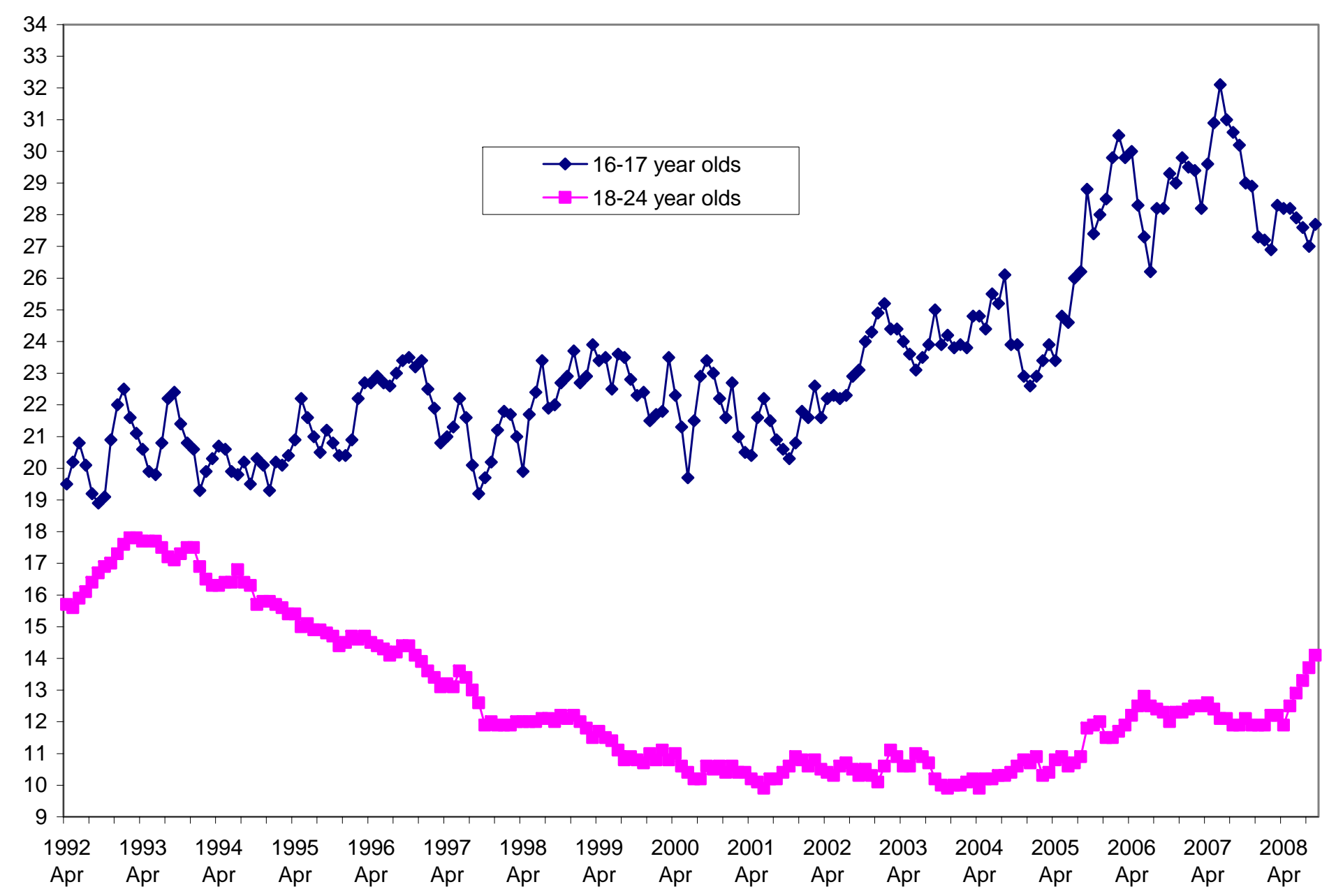




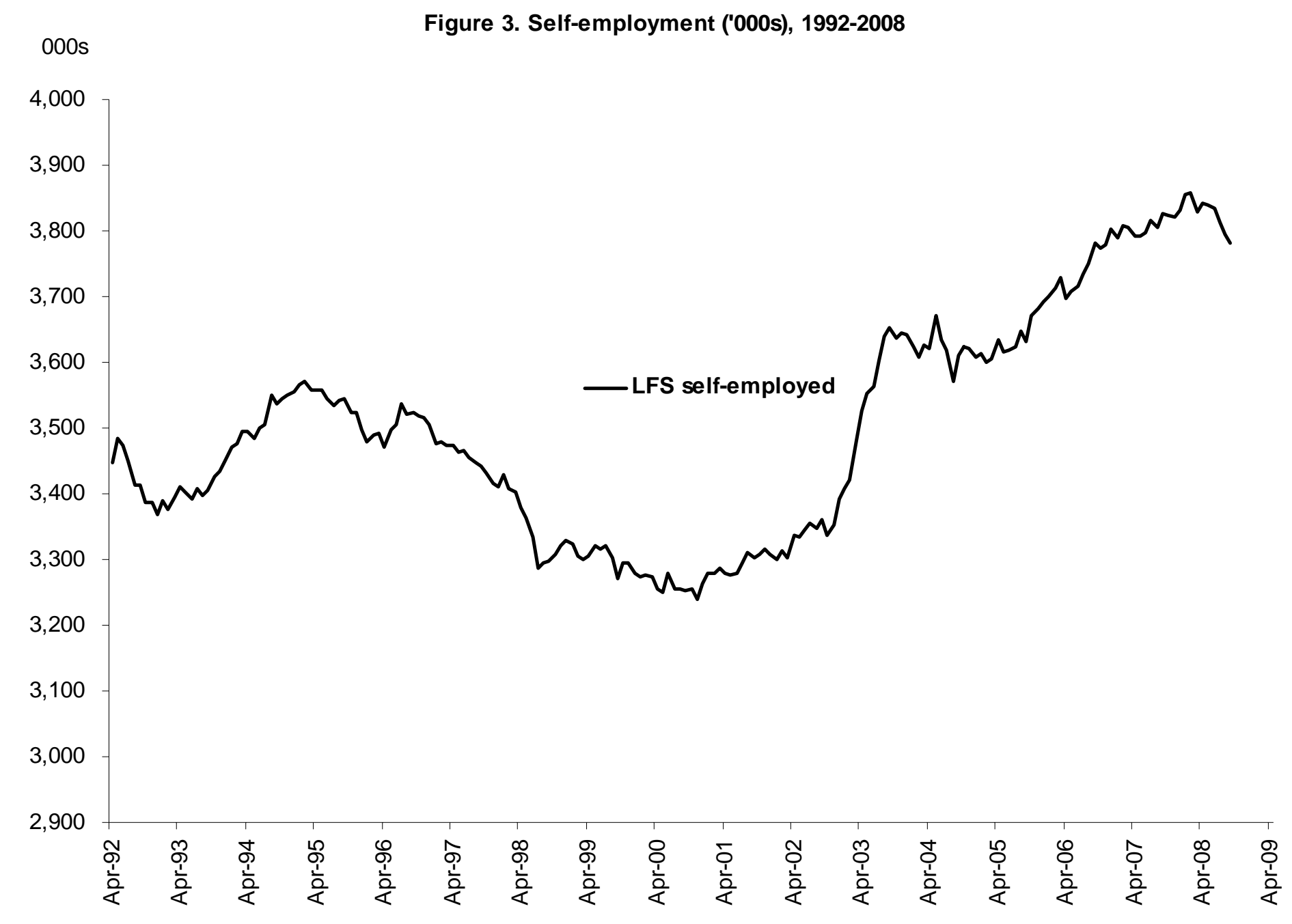

Source: LFS 
Survey Balance

Figure 4. Fear of unemployment, 1985-2008

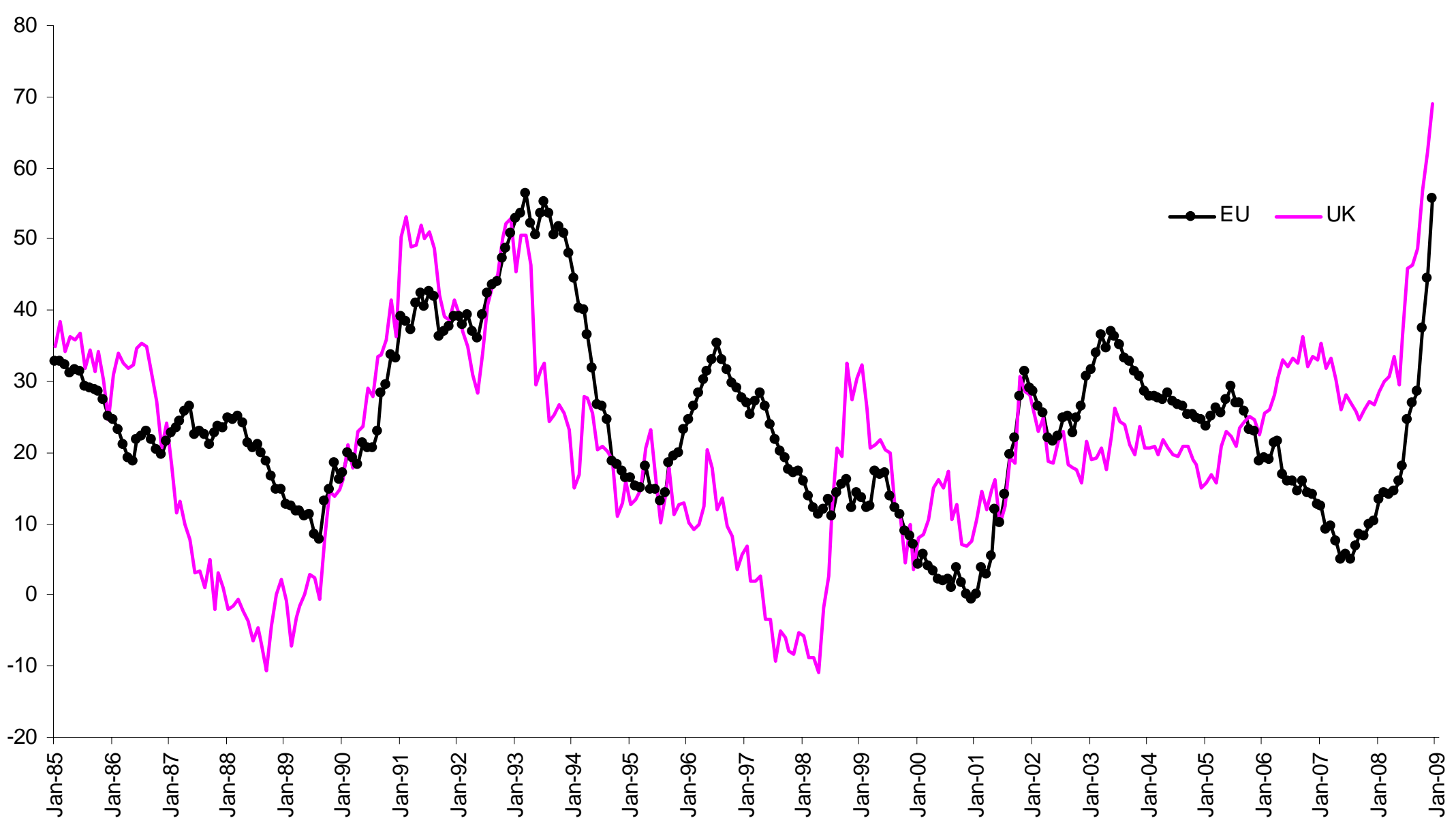

Source: EC Consumer Survey 


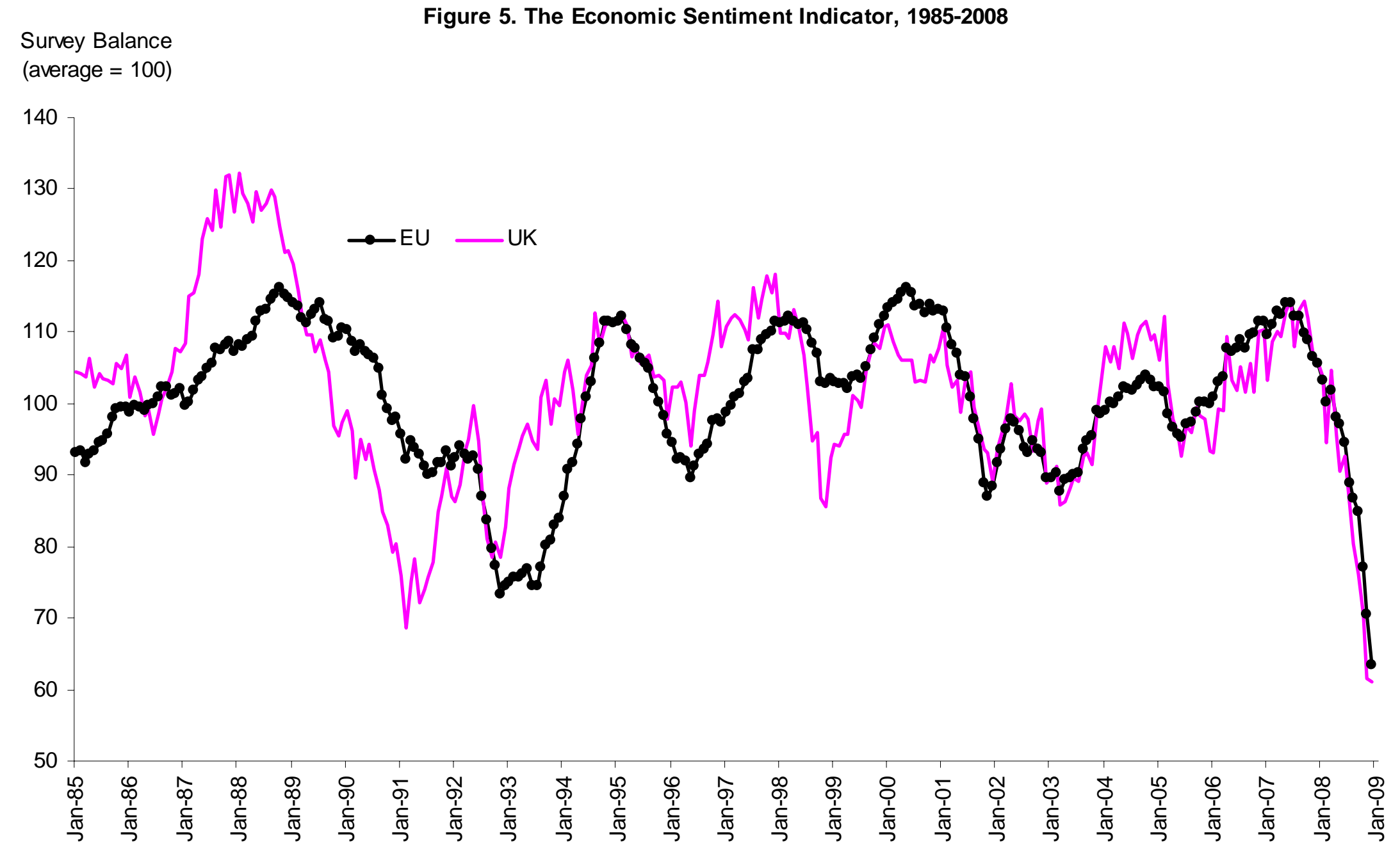

Source: EU Economic Sentiment Indicator 
Figure 6. CIPS Employment Surveys

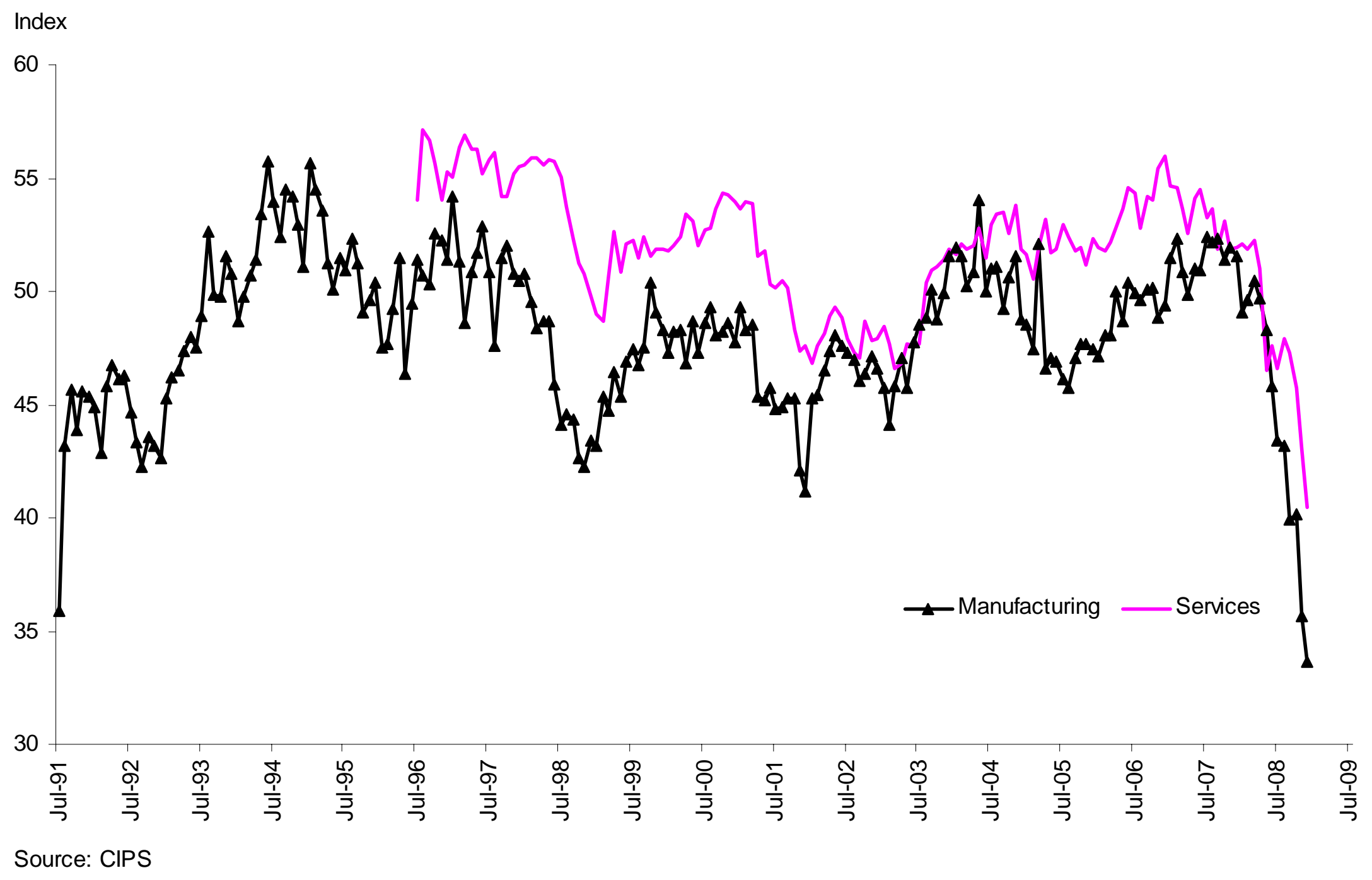

88 
Figure 7. REC Survey of Demand for Staff

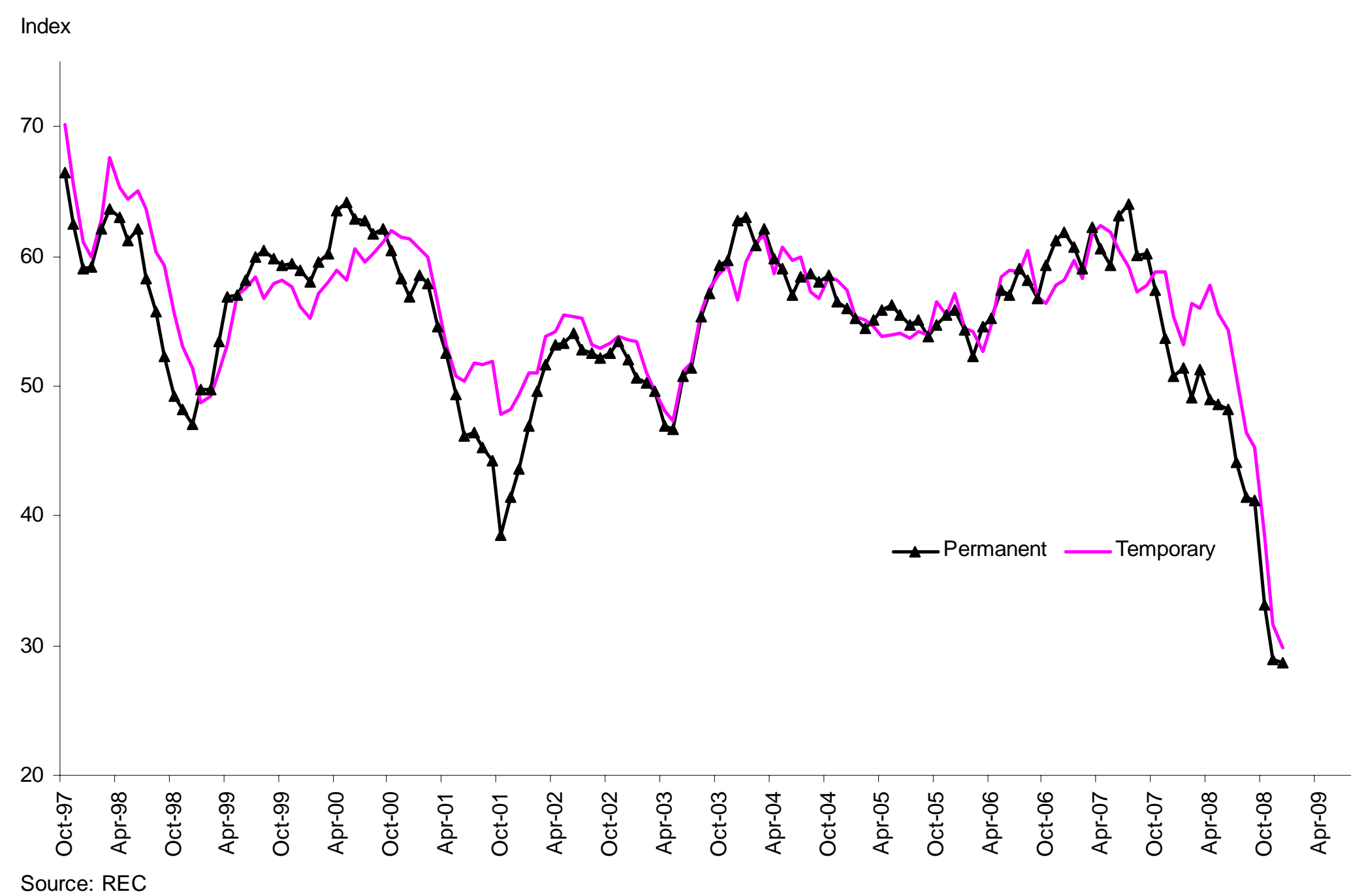


Figure 8. Bank of England Agents' Survey of Employment Intentions

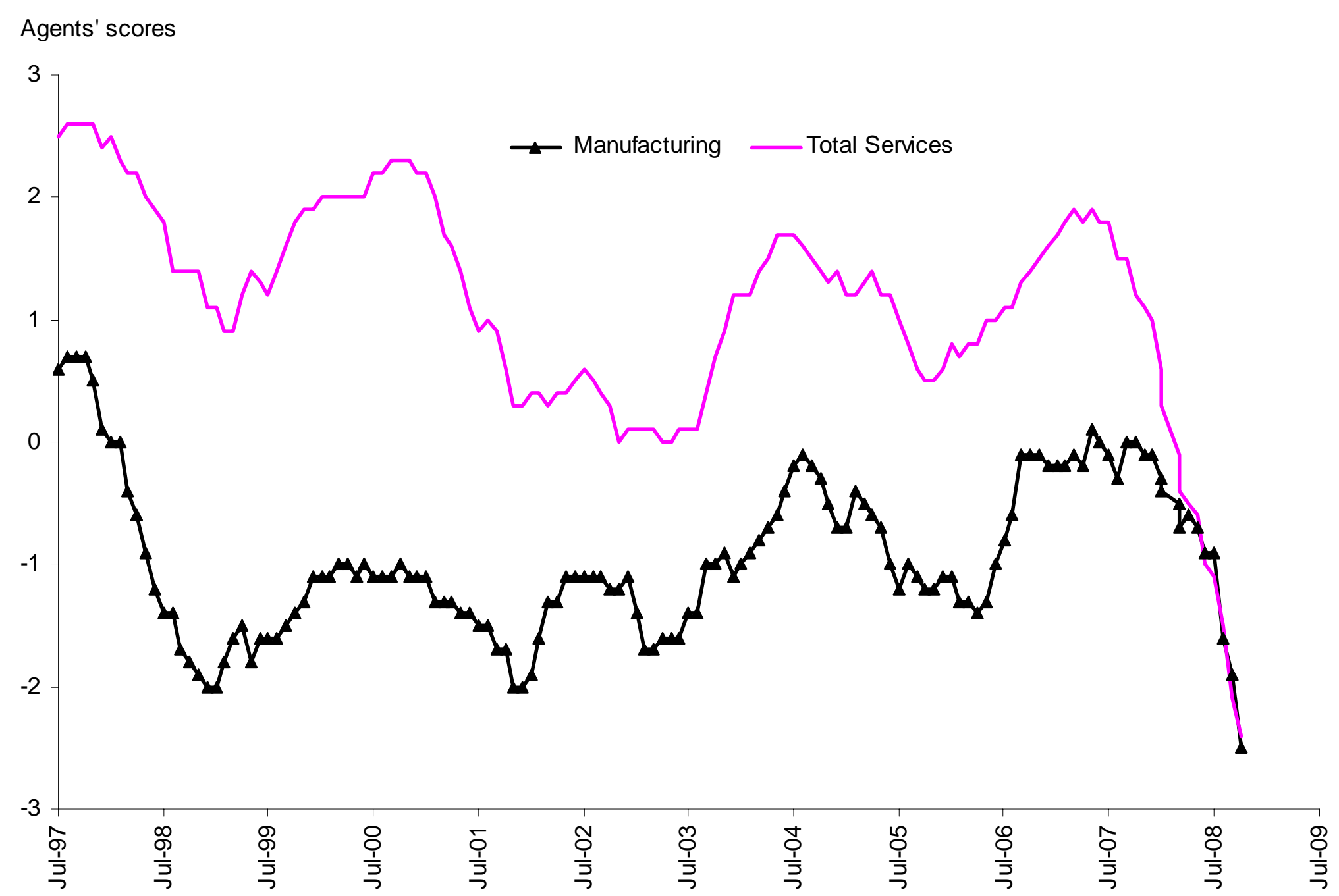

Source: Bank of England 
Figure 9. BCC Employment Intentions

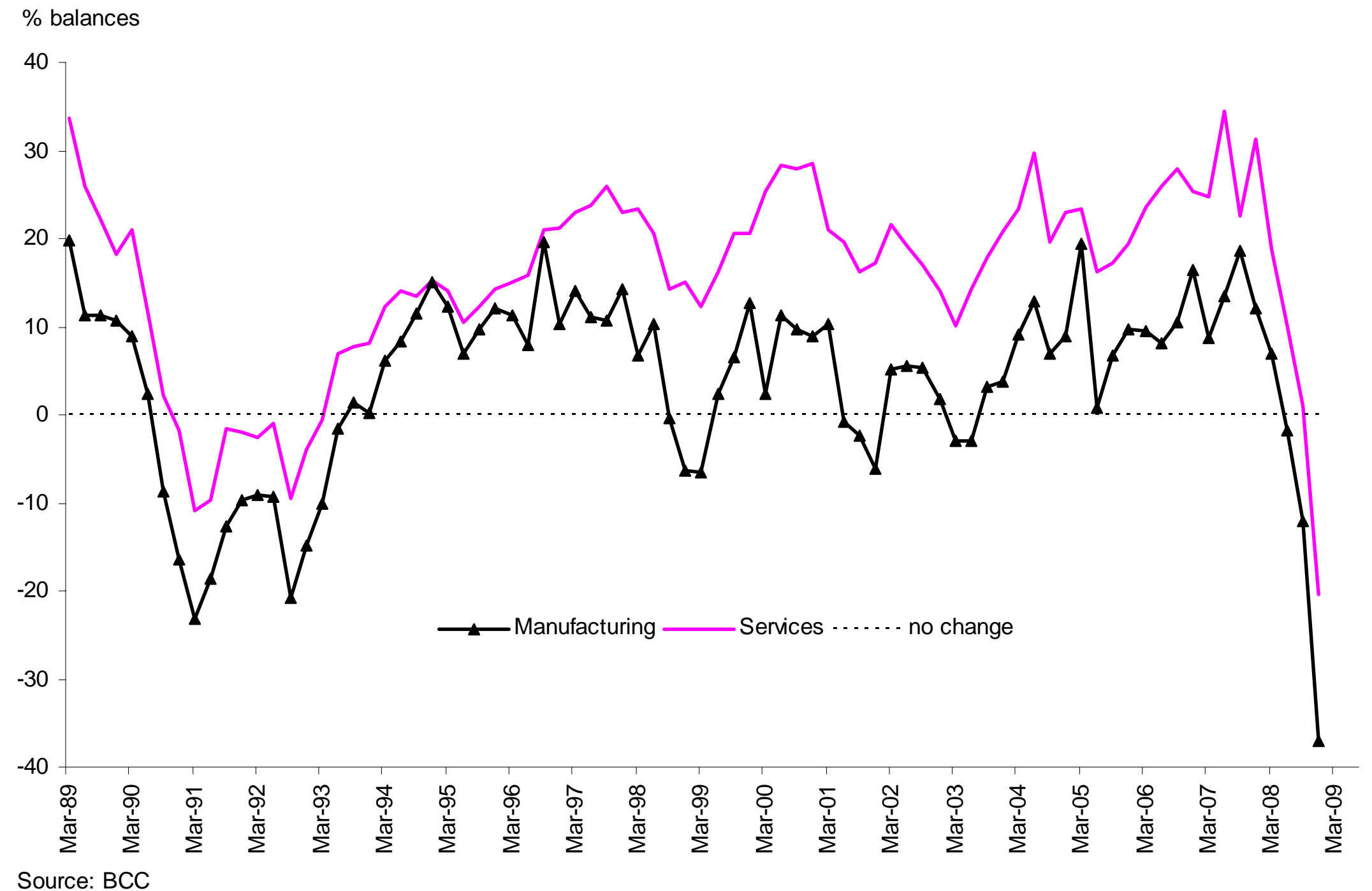


Figure 10 - Unemployment and GDP Deviations from Trend 1971 to 2008

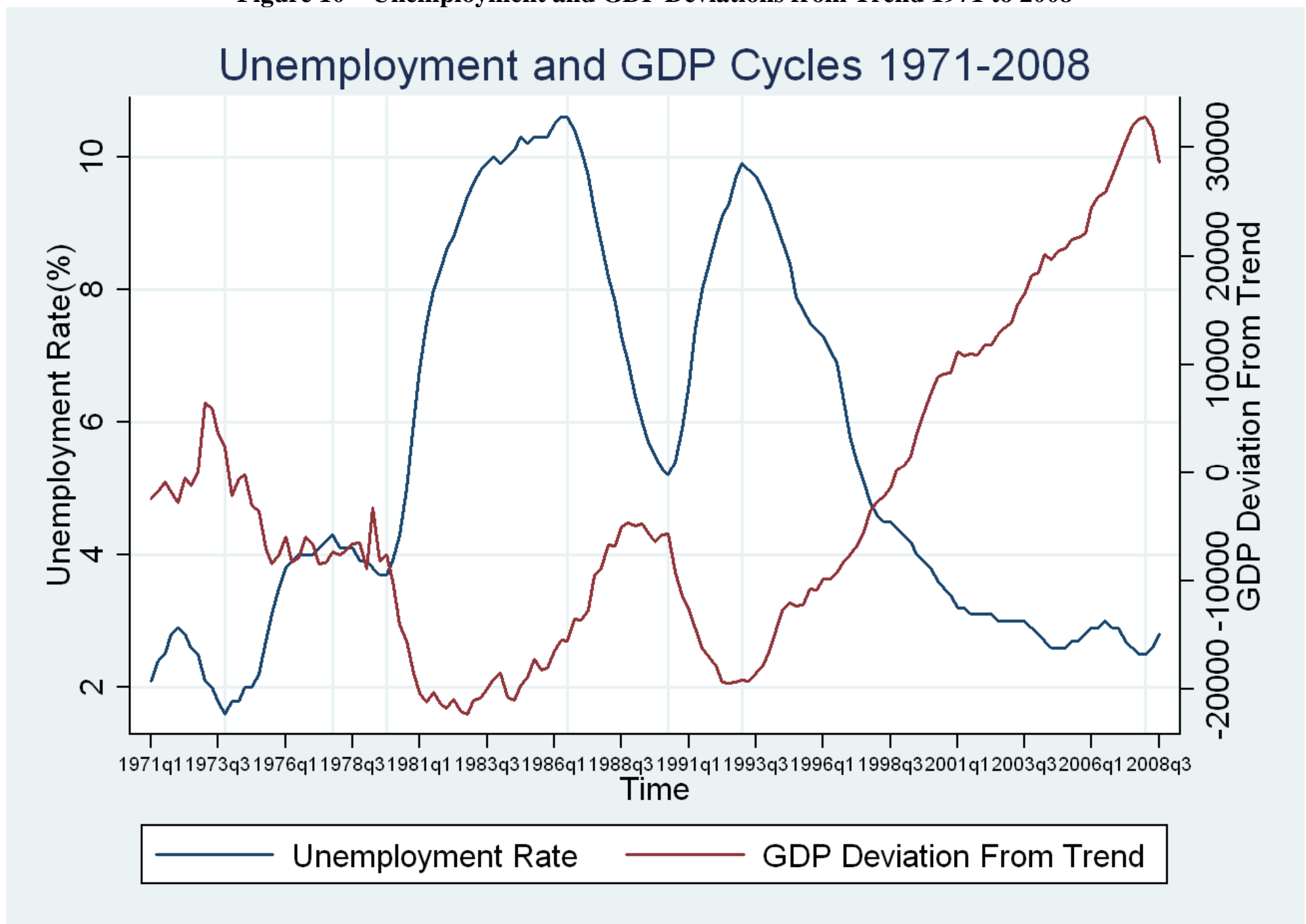


Figure 11. \% Increase in claimant count, 1991 and 2008 by region

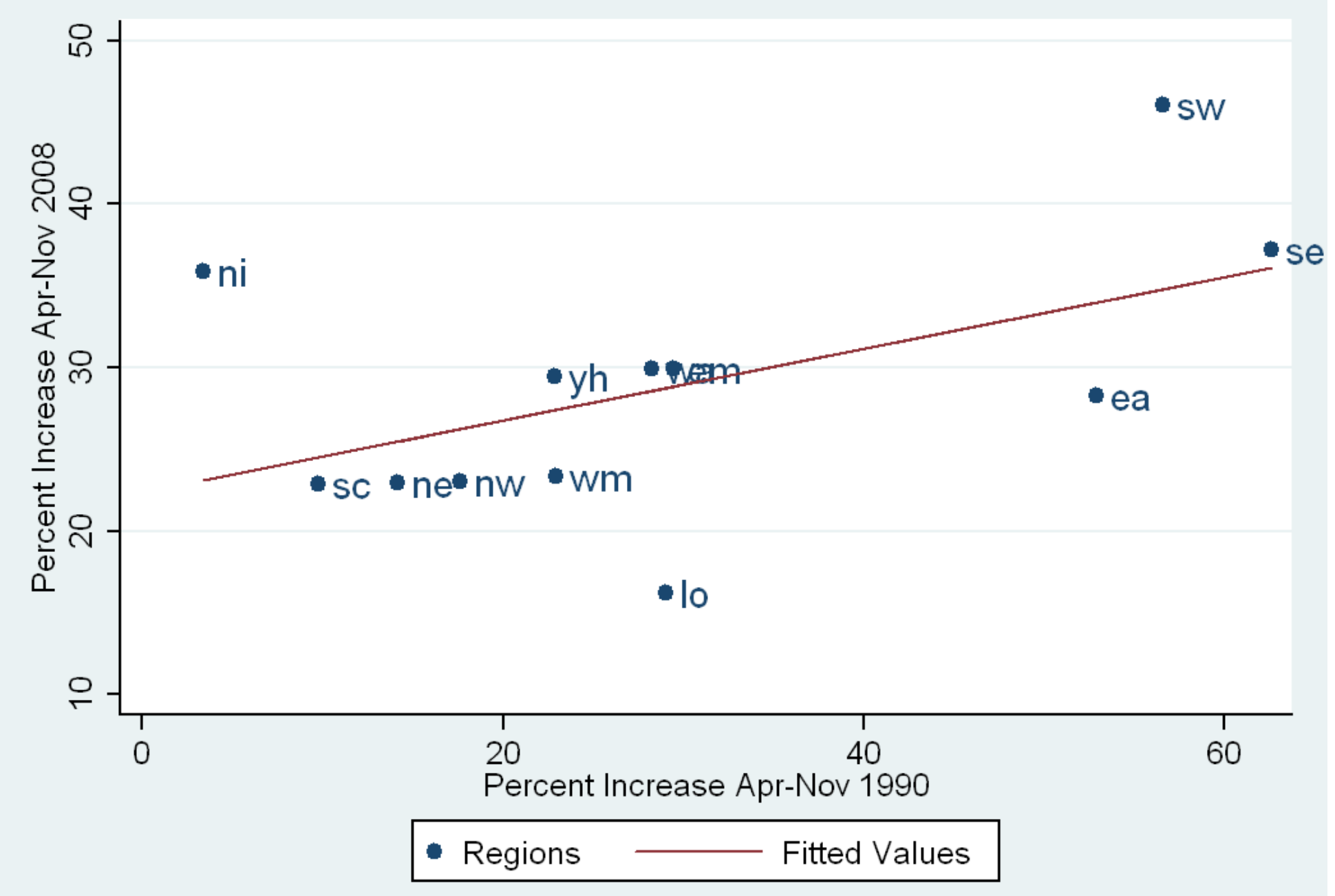


Figure 12. \% Increase in claimant count, 1991 and 2008 by TTWA

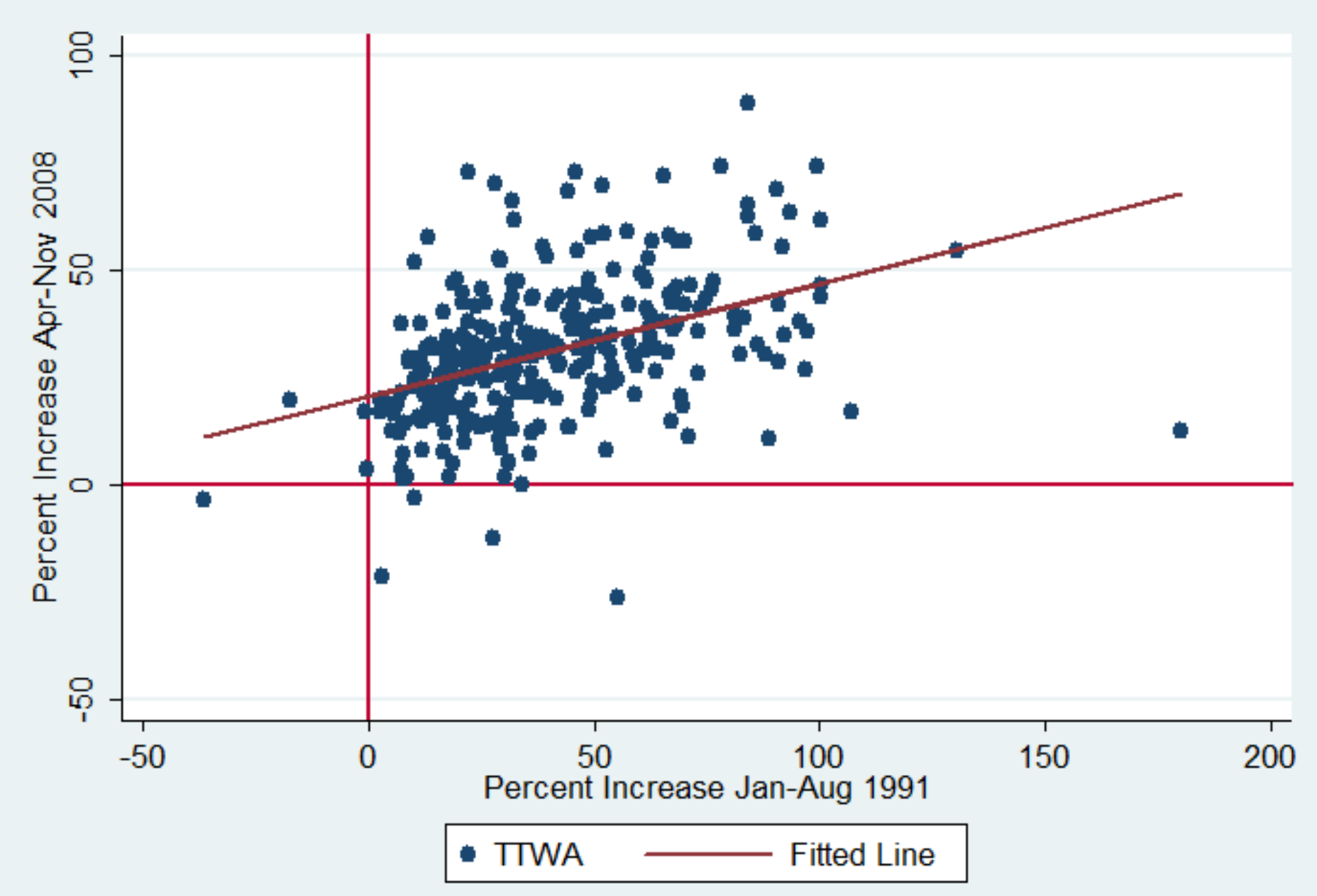


Figure 13: Employment Growth and Share of 16-24 Year Olds in “Lousy” and “Lovely” Jobs 2002-2008

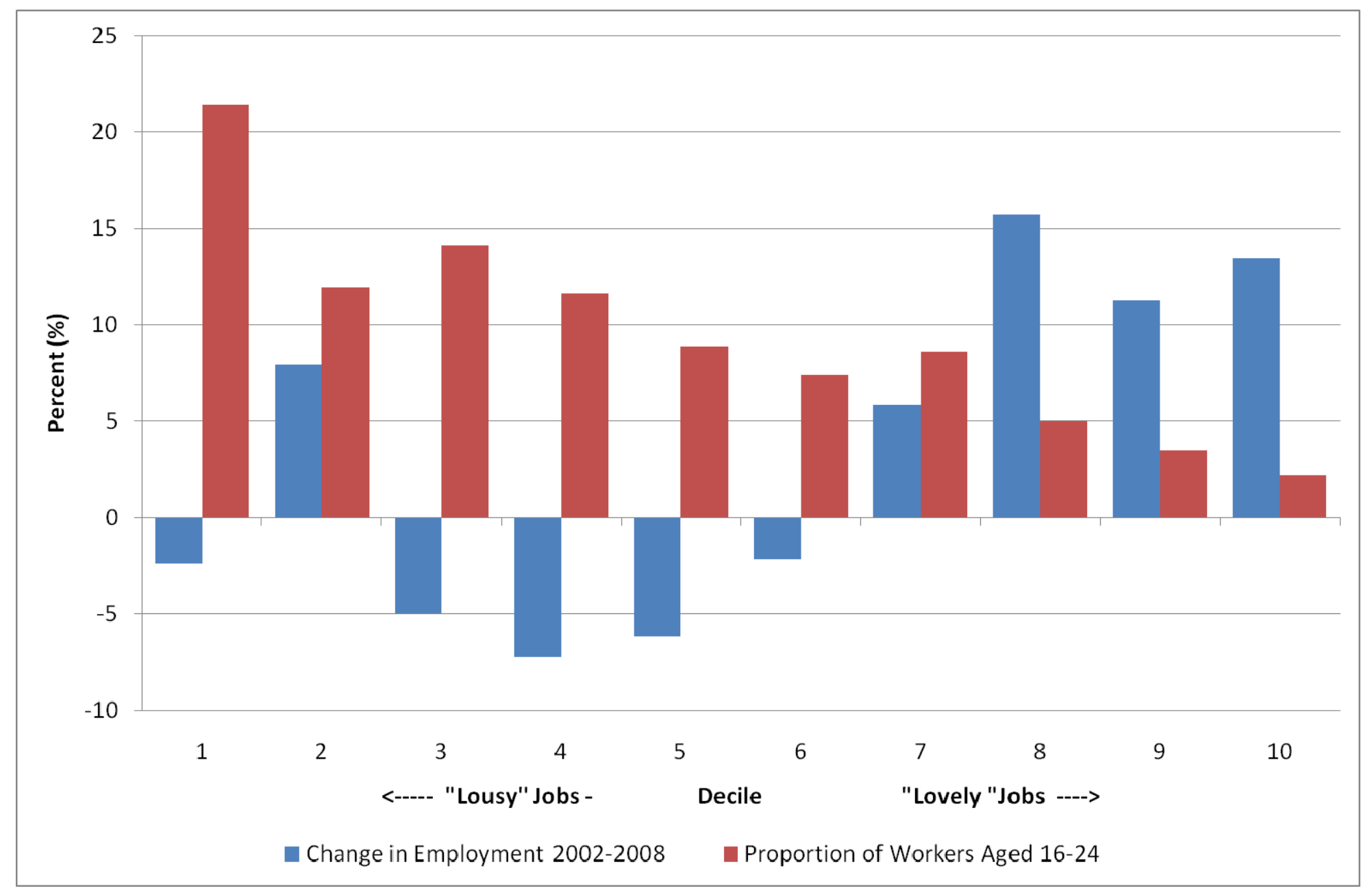


Figure 14: Expenditure on Active Labour Market Policies as a Share of GDP.

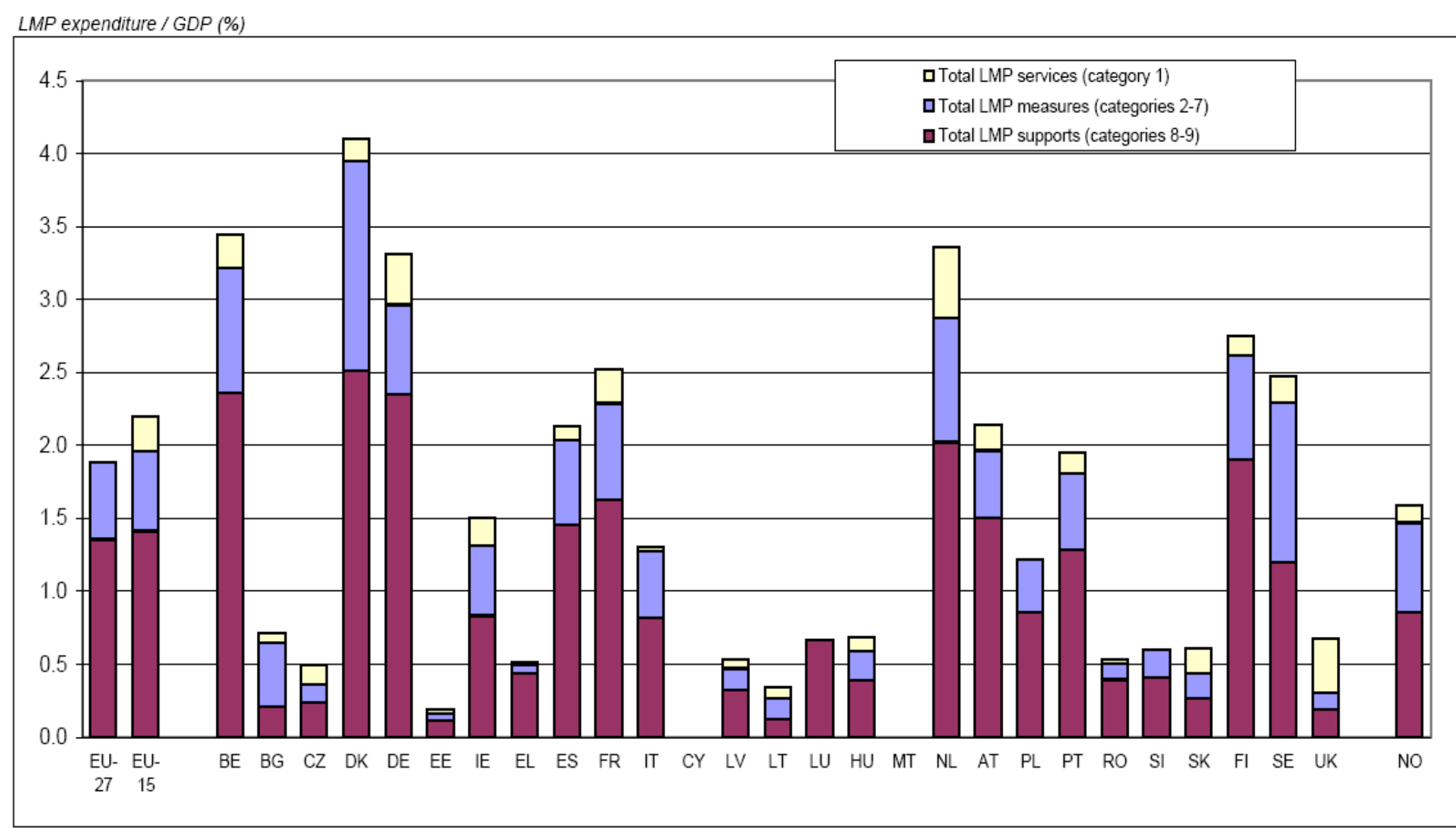

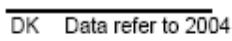

Source: Eurostat (2007) 
Appendix Table A1. Annual Standardized Unemployment Rates, 1996-2007 (\%)

\begin{tabular}{|c|c|c|c|c|c|c|c|c|c|c|c|c|}
\hline & 1996 & 1997 & 1998 & 1999 & 2000 & 2001 & 2002 & 2003 & 2004 & 2005 & 2006 & 2007 \\
\hline United Kingdom & 7.9 & 6.8 & 6.1 & 5.9 & 5.4 & 5.0 & 5.1 & 5.0 & 4.7 & 4.8 & 5.4 & 5.3 \\
\hline EU (27 countries) & : & : & : & : & 8.7 & 8.5 & 8.9 & 9.0 & 9.0 & 8.9 & 8.2 & 7.1 \\
\hline EU ( 25 countries) & : & : & 9.4 & 9.1 & 8.6 & 8.4 & 8.8 & 9.0 & 9.0 & 8.9 & 8.2 & 7.2 \\
\hline EU (15 countries) & 10.1 & 9.8 & 9.3 & 8.5 & 7.7 & 7.2 & 7.6 & 7.9 & 8.1 & 8.1 & 7.7 & 7.0 \\
\hline Euro area & 10.7 & 10.6 & 10.0 & 9.1 & 8.2 & 7.8 & 8.3 & 8.7 & 8.8 & 8.9 & 8.3 & 7.4 \\
\hline Euro area (15 countries) & 10.6 & 10.5 & 10.0 & 9.2 & 8.3 & 7.8 & 8.2 & 8.6 & 8.8 & 8.9 & 8.3 & 7.4 \\
\hline Euro area (13 countries) & 10.6 & 10.5 & 10.0 & 9.2 & 8.3 & 7.8 & 8.2 & 8.7 & 8.8 & 8.9 & 8.3 & 7.4 \\
\hline Euro area (12 countries) & 10.6 & 10.6 & 10.1 & 9.2 & 8.3 & 7.8 & 8.3 & 8.7 & 8.8 & 8.9 & 8.3 & 7.4 \\
\hline Austria & 4.3 & 4.4 & 4.5 & 3.9 & 3.6 & 3.6 & 4.2 & 4.3 & 4.9 & 5.2 & 4.8 & 4.4 \\
\hline Belgium & 9.5 & 9.2 & 9.3 & 8.5 & 6.9 & 6.6 & 7.5 & 8.2 & 8.4 & 8.5 & 8.3 & 7.5 \\
\hline Denmark & 6.3 & 5.2 & 4.9 & 5.2 & 4.3 & 4.5 & 4.6 & 5.4 & 5.5 & 4.8 & 3.9 & 3.8 \\
\hline Finland & 14.6 & 12.7 & 11.4 & 10.2 & 9.8 & 9.1 & 9.1 & 9.0 & 8.8 & 8.4 & 7.7 & 6.9 \\
\hline France & 11.5 & 11.5 & 11 & 10.4 & 9.0 & 8.3 & 8.6 & 9.0 & 9.3 & 9.2 & 9.2 & 8.3 \\
\hline Germany & 8.7 & 9.4 & 9.1 & 8.2 & 7.5 & 7.6 & 8.4 & 9.3 & 9.8 & 10.7 & 9.8 & 8.4 \\
\hline Greece & $:$ & $:$ & 10.8 & 12 & 11.2 & 10.7 & 10.3 & 9.7 & 10.5 & 9.9 & 8.9 & 8.3 \\
\hline Ireland & 11.7 & 9.9 & 7.5 & 5.7 & 4.3 & 4.0 & 4.5 & 4.7 & 4.5 & 4.4 & 4.5 & 4.6 \\
\hline Italy & 11.2 & 11.3 & 11.4 & 11.0 & 10.1 & 9.1 & 8.6 & 8.5 & 8.1 & 7.7 & 6.8 & 6.1 \\
\hline Japan & 3.4 & 3.4 & 4.1 & 4.7 & 4.7 & 5.0 & 5.4 & 5.3 & 4.7 & 4.4 & 4.1 & 3.9 \\
\hline Netherlands & 6.0 & 4.9 & 3.8 & 3.2 & 2.8 & 2.2 & 2.8 & 3.7 & 4.6 & 4.7 & 3.9 & 3.2 \\
\hline Norway & 4.7 & 4.0 & 3.2 & 3.2 & 3.4 & 3.6 & 3.9 & 4.5 & 4.4 & 4.6 & 3.5 & 2.6 \\
\hline Poland & : & 10.9 & 10.2 & 13.4 & 16.1 & 18.3 & 20 & 19.7 & 19.0 & 17.8 & 13.9 & 9.6 \\
\hline Portugal & 7.2 & 6.7 & 5.0 & 4.5 & 4.0 & 4.1 & 5.1 & 6.4 & 6.7 & 7.7 & 7.8 & 8.1 \\
\hline Spain & 17.8 & 16.7 & 15 & 12.5 & 11.1 & 10.3 & 11.1 & 11.1 & 10.6 & 9.2 & 8.5 & 8.3 \\
\hline Sweden & 9.6 & 9.9 & 8.2 & 6.7 & 5.6 & 4.9 & 4.9 & 5.6 & 6.3 & 7.4 & 7.0 & 6.1 \\
\hline United States & 5.4 & 4.9 & 4.5 & 4.2 & 4.0 & 4.8 & 5.8 & 6.0 & 5.5 & 5.1 & 4.6 & 4.6 \\
\hline
\end{tabular}


Appendix Table A2. Monthly Standardized Unemployment Rates, December 2007-November 2008

$\begin{array}{lcccccccccccc} & \text { Dec } & \text { Jan } & \text { Feb } & \text { March } & \text { April } & \text { May } & \text { June } & \text { July } & \text { August } & \text { Sept } & \text { Oct } & \text { Nov } \\ & 2007 & 2008 & 2008 & 2008 & 2008 & 2008 & 2008 & 2008 & 2008 & 2008 & 2008 & 2008 \\ \text { United Kingdom } & 5.1 & 5.1 & 5.1 & 5.2 & 5.2 & 5.4 & 5.5 & 5.7 & 5.8 & 5.9 & 6.0 & 6.1 \\ \text { Euro area } & 7.2 & 7.2 & 7.2 & 7.2 & 7.3 & 7.4 & 7.4 & 7.5 & 7.5 & 7.6 & 7.7 & : \\ \text { Euro area (15 countries) } & 7.2 & 7.2 & 7.2 & 7.2 & 7.3 & 7.4 & 7.4 & 7.5 & 7.5 & 7.6 & 7.7 & : \\ \text { Euro area (13 countries) } & 7.2 & 7.3 & 7.2 & 7.2 & 7.3 & 7.4 & 7.4 & 7.5 & 7.5 & 7.6 & 7.7 & : \\ \text { Euro area (12 countries) } & 7.2 & 7.3 & 7.2 & 7.2 & 7.3 & 7.4 & 7.4 & 7.5 & 7.6 & 7.6 & 7.7 & : \\ \text { EU (27 countries) } & 6.8 & 6.8 & 6.8 & 6.8 & 6.8 & 6.9 & 6.9 & 6.9 & 7.0 & 7.0 & 7.1 & : \\ \text { EU (25 countries) } & 6.9 & 6.9 & 6.8 & 6.8 & 6.9 & 6.9 & 7.0 & 7.0 & 7.1 & 7.1 & 7.2 & : \\ \text { EU (15 countries) } & 6.8 & 6.8 & 6.8 & 6.8 & 6.9 & 7.0 & 7.0 & 7.1 & 7.2 & 7.2 & 7.3 & : \\ \text { Austria } & 4.0 & 4.1 & 4.0 & 3.9 & 3.7 & 3.6 & 3.4 & 3.4 & 3.2 & 3.1 & 3.0 & : \\ \text { Belgium } & 7.0 & 7.0 & 6.9 & 6.8 & 6.8 & 6.6 & 6.6 & 6.6 & 6.6 & 6.6 & 6.6 & : \\ \text { Denmark } & 3.3 & 3.3 & 3.2 & 3.2 & 3.2 & 3.2 & 3.1 & 3.0 & 2.9 & 3.0 & 3.2 & : \\ \text { Finland } & 6.5 & 6.4 & 6.3 & 6.3 & 6.3 & 6.3 & 6.4 & 6.4 & 6.4 & 6.4 & 6.4 & 6.4 \\ \text { France } & 7.7 & 7.8 & 7.7 & 7.6 & 7.7 & 7.7 & 7.7 & 7.9 & 8.1 & 8.0 & 8.2 & : \\ \text { Germany } & 7.9 & 7.7 & 7.6 & 7.4 & 7.4 & 7.4 & 7.3 & 7.2 & 7.1 & 7.1 & 7.1 & : \\ \text { Greece } & 8.0 & 7.8 & 7.8 & 7.8 & 7.5 & 7.5 & 7.5 & : & : & : & : & : \\ \text { Ireland } & 4.7 & 4.7 & 4.9 & 5.2 & 5.3 & 5.5 & 5.7 & 6.0 & 6.3 & 6.6 & 7.1 & : \\ \text { Italy } & 6.3 & 6.7 & 6.7 & 6.7 & 6.8 & 6.8 & 6.8 & : & : & : & : & : \\ \text { Japan } & 3.8 & 3.8 & 3.9 & 3.8 & 4.0 & 4.0 & 4.1 & 4.0 & 4.2 & 4.0 & 3.7 & : \\ \text { Netherlands } & 2.9 & 2.8 & 2.8 & 2.9 & 2.9 & 2.8 & 2.7 & 2.7 & 2.7 & 2.7 & 2.7 & 2.7 \\ \text { Norway } & 2.5 & 2.5 & 2.5 & 2.4 & 2.5 & 2.5 & 2.6 & 2.4 & 2.4 & 2.5 & : & : \\ \text { Portugal } & 7.7 & 7.7 & 7.7 & 7.6 & 7.6 & 7.7 & 7.8 & 7.8 & 7.8 & 7.8 & 7.8 & : \\ \text { Spain } & 8.7 & 9.0 & 9.3 & 9.6 & 10.1 & 10.6 & 11.0 & 11.3 & 11.6 & 12.1 & 12.8 & : \\ \text { Sweden } & 5.8 & 5.8 & 5.9 & 5.9 & 5.9 & 5.8 & 5.8 & 5.9 & 6.2 & 6.4 & 6.7 & 7.0 \\ \text { United States } & 5.0 & 4.9 & 4.8 & 5.1 & 5.0 & 5.5 & 5.5 & 5.7 & 6.1 & 6.1 & 6.5 & :\end{array}$

Notes :=Not available. Source: Eurostat 


\begin{tabular}{|c|c|c|c|c|c|c|c|c|}
\hline \multicolumn{9}{|c|}{ Appendix Table B1. Unemployment rates of $15-24$ year olds (Source: OECD) } \\
\hline & 2000 & 2001 & 2002 & 2003 & 2004 & 2005 & 2006 & 2007 \\
\hline United Kingdom & 11.7 & 10.4 & 11.0 & 11.5 & 10.9 & 12.2 & 13.9 & 14.4 \\
\hline Australia & 12.1 & 13.6 & 12.9 & 12.2 & 11.6 & 10.8 & 10.0 & 9.4 \\
\hline Austria & 5.1 & 5.6 & 6.2 & 7.0 & 9.7 & 10.3 & 9.1 & 8.7 \\
\hline Belgium & 15.2 & 15.3 & 15.7 & 19.0 & 17.5 & 19.9 & 18.9 & 19.2 \\
\hline Canada & 12.7 & 12.9 & 13.6 & 13.6 & 13.4 & 12.4 & 11.6 & 11.2 \\
\hline Czech Republic & 17.0 & 16.6 & 16.0 & 17.6 & 20.4 & 19.3 & 17.5 & 10.7 \\
\hline Denmark & 6.7 & 8.3 & 7.1 & 9.8 & 7.8 & 7.9 & 7.6 & 7.2 \\
\hline Finland & 20.3 & 18.8 & 19.5 & 20.4 & 19.5 & 18.9 & 17.6 & 15.7 \\
\hline France & 20.7 & 18.7 & 20.2 & 18.3 & 19.7 & 20.2 & 21.3 & 18.7 \\
\hline Germany & 8.4 & 8.3 & 9.8 & 10.6 & 12.6 & 15.2 & 13.6 & 11.7 \\
\hline Greece & 29.5 & 28.0 & 26.1 & 25.7 & 26.5 & 25.3 & 24.5 & 22.0 \\
\hline Hungary & 12.7 & 11.2 & 12.6 & 13.4 & 15.5 & 19.4 & 19.1 & 18.0 \\
\hline Iceland & 4.7 & 4.8 & 7.2 & 8.2 & 8.1 & 7.2 & 8.4 & 7.2 \\
\hline Ireland & 6.4 & 6.2 & 7.7 & 7.8 & 8.1 & 8.3 & 8.3 & 8.7 \\
\hline Italy & 29.7 & 27.0 & 26.3 & 26.3 & 23.5 & 24.0 & 21.6 & 20.3 \\
\hline Japan & 9.2 & 9.7 & 10.0 & 10.2 & 9.5 & 8.6 & 8.0 & 7.7 \\
\hline Korea & 10.8 & 10.2 & 8.5 & 10.1 & 10.5 & 10.2 & 10.0 & 8.8 \\
\hline Luxembourg & 6.4 & 6.3 & 7.0 & 10.9 & 16.9 & 13.7 & 16.2 & 14.9 \\
\hline Mexico & 5.1 & 4.9 & 5.9 & 6.2 & 7.6 & 6.6 & 6.2 & 6.7 \\
\hline Netherlands & 6.1 & 5.8 & 6.0 & 7.8 & 9.2 & 9.6 & 7.6 & 7.3 \\
\hline New Zealand & 13.2 & 11.8 & 11.5 & 10.2 & 9.3 & 9.4 & 9.6 & 9.7 \\
\hline Norway & 10.2 & 10.5 & 11.5 & 11.7 & 11.7 & 12.0 & 8.3 & 7.5 \\
\hline Poland & 35.2 & 41.0 & 43.9 & 43.0 & 40.8 & 37.8 & 29.8 & 21.7 \\
\hline Portugal & 8.6 & 9.4 & 11.5 & 14.6 & 15.3 & 16.1 & 16.2 & 16.6 \\
\hline Slovak Republic & 37.0 & 39.1 & 37.4 & 33.1 & 32.7 & 29.9 & 26.6 & 20.1 \\
\hline Spain & 25.3 & 20.8 & 22.2 & 22.7 & 22.0 & 19.7 & 17.9 & 18.2 \\
\hline Sweden & 11.9 & 11.8 & 12.9 & 13.8 & 17.0 & 22.3 & 21.3 & 18.9 \\
\hline Switzerland & 4.9 & 5.5 & 5.6 & 8.5 & 7.7 & 8.8 & 7.7 & 7.1 \\
\hline Turkey & 13.1 & 16.2 & 19.2 & 20.5 & 19.7 & 19.3 & 18.7 & 19.6 \\
\hline United States & 9.3 & 10.6 & 12.0 & 12.4 & 11.8 & 11.3 & 10.5 & 10.5 \\
\hline European Union 19 & 17.7 & 16.9 & 17.6 & 17.9 & 18.0 & 18.3 & 17.2 & 15.4 \\
\hline European Union 15 & 15.7 & 14.1 & 14.8 & 15.4 & 15.7 & 16.4 & 15.8 & 14.9 \\
\hline Europe & 16.6 & 16.5 & 17.6 & 18.1 & 18.0 & 18.2 & 17.1 & 15.7 \\
\hline OECD countries & 11.9 & 12.3 & 13.3 & 13.7 & 13.6 & 13.3 & 12.4 & 11.9 \\
\hline
\end{tabular}


Appendix Table B2. Employment/Population rates of 15-24 year olds (Source: OECD)

\begin{tabular}{|c|c|c|c|c|c|c|c|c|}
\hline & 2000 & 2001 & 2002 & 2003 & 2004 & 2005 & 2006 & 2007 \\
\hline United Kingdom & 61.5 & 61.0 & 60.9 & 59.7 & 60.1 & 58.6 & 57.3 & 55.9 \\
\hline Australia & 62.1 & 61.2 & 61.1 & 61.8 & 62.4 & 63.6 & 63.9 & 64.2 \\
\hline Austria & 52.8 & 51.6 & 51.7 & 51.1 & 51.9 & 53.1 & 54.0 & 55.5 \\
\hline Belgium & 30.3 & 28.5 & 28.5 & 27.1 & 28.1 & 26.6 & 26.2 & 26.8 \\
\hline Canada & 56.3 & 56.3 & 57.5 & 58.3 & 58.0 & 57.8 & 58.7 & 59.5 \\
\hline Czech Republic & 38.3 & 36.1 & 33.7 & 31.4 & 28.5 & 27.3 & 27.7 & 28.5 \\
\hline Denmark & 67.1 & 61.7 & 64.0 & 59.4 & 61.3 & 62.0 & 63.7 & 67.4 \\
\hline Finland & 42.9 & 43.5 & 42.4 & 41.4 & 41.3 & 42.1 & 44.1 & 46.4 \\
\hline France & 23.2 & 24.3 & 24.1 & 29.7 & 29.3 & 29.3 & 28.9 & 30.1 \\
\hline Germany & 47.2 & 47.0 & 44.8 & 42.4 & 41.9 & 42.6 & 44.0 & 45.9 \\
\hline Greece & 26.9 & 26.0 & 26.8 & 26.2 & 27.4 & 25.3 & 24.5 & 24.2 \\
\hline Hungary & 32.5 & 30.7 & 28.5 & 26.7 & 23.6 & 21.8 & 21.7 & 21.0 \\
\hline Iceland & 68.2 & 66.8 & 59.4 & 68.1 & 66.3 & 71.6 & 72.9 & 74.3 \\
\hline Ireland & 48.2 & 47.0 & 44.8 & 45.2 & 44.7 & 46.4 & 48.4 & 48.8 \\
\hline Italy & 27.8 & 27.4 & 26.7 & 26.0 & 27.2 & 25.5 & 25.5 & 24.7 \\
\hline Japan & 42.7 & 42.0 & 41.0 & 40.3 & 40.0 & 40.9 & 41.4 & 41.4 \\
\hline Korea & 29.4 & 30.1 & 31.5 & 30.8 & 31.2 & 29.9 & 27.2 & 25.7 \\
\hline Luxembourg & 31.8 & 32.3 & 32.3 & 27.0 & 23.3 & 24.9 & 23.3 & 22.1 \\
\hline Mexico & 48.9 & 47.2 & 45.4 & 44.1 & 44.3 & 43.7 & 44.8 & 44.2 \\
\hline Netherlands & 66.5 & 66.8 & 66.7 & 64.9 & 63.2 & 61.9 & 63.9 & 65.4 \\
\hline New Zealand & 54.6 & 55.8 & 56.6 & 56.3 & 56.8 & 56.9 & 58.8 & 58.7 \\
\hline Norway & 58.1 & 56.5 & 56.9 & 55.3 & 54.4 & 52.9 & 55.8 & 56.0 \\
\hline Poland & 24.5 & 22.1 & 20.0 & 19.6 & 20.0 & 20.9 & 24.0 & 25.8 \\
\hline Portugal & 42.0 & 42.7 & 41.9 & 38.4 & 36.9 & 36.1 & 35.8 & 34.9 \\
\hline Slovak Republic & 29.0 & 27.9 & 27.2 & 27.6 & 26.5 & 25.6 & 25.7 & 27.6 \\
\hline Spain & 36.3 & 37.1 & 36.6 & 36.8 & 38.4 & 41.9 & 43.3 & 42.9 \\
\hline Sweden & 46.1 & 47.8 & 46.5 & 45.1 & 42.8 & 42.5 & 44.0 & 46.3 \\
\hline Switzerland & 65.1 & 63.9 & 65.4 & 63.5 & 61.9 & 59.9 & 63.3 & 62.6 \\
\hline Turkey & 37.0 & 35.3 & 33.0 & 30.5 & 31.6 & 31.2 & 30.8 & 30.4 \\
\hline United States & 59.7 & 57.7 & 55.7 & 53.9 & 53.9 & 53.9 & 54.2 & 53.1 \\
\hline European Union 19 & 38.5 & 38.2 & 37.4 & 37.1 & 37.3 & 37.4 & 38.1 & 38.8 \\
\hline European Union 15 & 40.7 & 40.9 & 40.2 & 40.1 & 40.4 & 40.4 & 40.9 & 41.5 \\
\hline Europe & 38.7 & 38.1 & 37.1 & 36.4 & 36.7 & 36.7 & 37.3 & 37.9 \\
\hline OECD countries & 45.6 & 44.8 & 43.7 & 42.8 & 43.1 & 43.1 & 43.5 & 43.5 \\
\hline
\end{tabular}




\begin{tabular}{|c|c|c|c|c|c|c|c|c|}
\hline \multicolumn{9}{|c|}{ Appendix Table B3. Participation rates of 15-24 year olds (Source: OECD) } \\
\hline & 2000 & 2001 & 2002 & 2003 & 2004 & 2005 & 2006 & 2007 \\
\hline United Kingdom & 69.7 & 68.2 & 68.5 & 67.4 & 67.4 & 66.7 & 66.6 & 65.3 \\
\hline Australia & 70.6 & 70.9 & 70.1 & 70.4 & 70.6 & 71.3 & 71.0 & 70.8 \\
\hline Austria & 55.7 & 54.7 & 55.2 & 55.0 & 57.4 & 59.2 & 59.4 & 60.8 \\
\hline Belgium & 35.7 & 33.6 & 33.8 & 33.5 & 34.0 & 33.2 & 32.3 & 33.1 \\
\hline Canada & 64.4 & 64.7 & 66.6 & 67.4 & 67.0 & 65.9 & 66.4 & 67.0 \\
\hline Czech Republic & 46.1 & 43.2 & 40.1 & 38.1 & 35.8 & 33.9 & 33.5 & 31.9 \\
\hline Denmark & 71.9 & 67.2 & 68.8 & 65.9 & 66.4 & 67.2 & 69.0 & 72.6 \\
\hline Finland & 53.8 & 53.6 & 52.7 & 52.0 & 51.3 & 51.9 & 53.6 & 55.0 \\
\hline France & 29.3 & 29.9 & 30.2 & 36.4 & 36.5 & 36.7 & 36.7 & 37.0 \\
\hline Germany & 51.5 & 51.3 & 49.7 & 47.4 & 48.0 & 50.2 & 50.9 & 52.0 \\
\hline Greece & 38.1 & 36.2 & 36.3 & 35.2 & 37.3 & 33.9 & 32.5 & 31.0 \\
\hline Hungary & 37.2 & 34.6 & 32.6 & 30.8 & 27.9 & 27.1 & 26.8 & 25.6 \\
\hline Iceland & 71.6 & 70.2 & 64.0 & 74.2 & 72.1 & 77.1 & 79.5 & 80.1 \\
\hline Ireland & 51.6 & 50.1 & 48.6 & 49.1 & 48.6 & 50.6 & 52.8 & 53.4 \\
\hline Italy & 39.5 & 37.6 & 36.3 & 35.3 & 35.6 & 33.5 & 32.5 & 30.9 \\
\hline Japan & 47.0 & 46.5 & 45.6 & 44.8 & 44.2 & 44.8 & 45.0 & 44.9 \\
\hline Korea & 33.0 & 33.5 & 34.4 & 34.3 & 34.8 & 33.3 & 30.2 & 28.2 \\
\hline Luxembourg & 34.0 & 34.5 & 34.7 & 30.4 & 28.0 & 28.8 & 27.8 & 26.0 \\
\hline Mexico & 51.5 & 49.6 & 48.2 & 47.0 & 48.0 & 46.8 & 47.8 & 47.4 \\
\hline Netherlands & 70.8 & 71.0 & 70.9 & 70.4 & 69.6 & 68.5 & 69.2 & 70.5 \\
\hline New Zealand & 62.9 & 63.3 & 64.0 & 62.8 & 62.6 & 62.8 & 65.0 & 65.0 \\
\hline Norway & 64.7 & 63.1 & 64.2 & 62.6 & 61.6 & 60.2 & 60.9 & 60.6 \\
\hline Poland & 37.8 & 37.4 & 35.6 & 34.4 & 33.9 & 33.5 & 34.2 & 33.0 \\
\hline Portugal & 46.0 & 47.1 & 47.3 & 45.0 & 43.6 & 43.0 & 42.7 & 41.9 \\
\hline Slovak Republic & 46.0 & 45.7 & 43.5 & 41.2 & 39.4 & 36.5 & 35.1 & 34.5 \\
\hline Spain & 48.5 & 46.8 & 47.0 & 47.6 & 49.2 & 52.1 & 52.7 & 52.4 \\
\hline Sweden & 52.3 & 54.2 & 53.4 & 52.3 & 51.5 & 54.7 & 56.0 & 57.1 \\
\hline Switzerland & 68.4 & 67.6 & 69.3 & 69.3 & 67.0 & 65.6 & 68.6 & 67.4 \\
\hline Turkey & 42.5 & 42.1 & 40.9 & 38.4 & 39.3 & 38.7 & 37.9 & 37.8 \\
\hline United States & 65.8 & 64.5 & 63.3 & 61.6 & 61.1 & 60.8 & 60.6 & 59.4 \\
\hline European Union 19 & 46.8 & 46.0 & 45.4 & 45.2 & 45.5 & 45.8 & 46.0 & 45.9 \\
\hline European Union 15 & 48.3 & 47.6 & 47.2 & 47.4 & 47.9 & 48.4 & 48.6 & 48.7 \\
\hline Europe & 46.4 & 45.7 & 45.0 & 44.4 & 44.8 & 44.9 & 44.9 & 44.9 \\
\hline OECD countries & 51.8 & 51.0 & 50.4 & 49.6 & 49.8 & 49.7 & 49.7 & 49.4 \\
\hline
\end{tabular}


Appendix Table C1. The situation of youth in the labour market, 1996 and 2006 (Source OECD 2008b)

Australia

Austria

Belgium

Canada

Czech Republic

Denmark

Finland

France

Germany

Greece

Hungary

Iceland

Ireland

Italy

Japan

Korea

Luxembourg

Mexico

Netherlands

New Zealand

Norway

Poland

Portugal

Slovak Republic

\begin{tabular}{|c|c|c|c|c|c|c|c|c|c|}
\hline \multicolumn{2}{|c|}{$\begin{array}{l}\text { Incidence of long-term } \\
\text { unemployment }\end{array}$} & \multicolumn{2}{|c|}{ NEET rates } & \multicolumn{2}{|c|}{ Low-skilled NEET } & \multicolumn{2}{|c|}{$\begin{array}{l}\text { School drop-out rates of } \\
\text { teenagers }(15-19)\end{array}$} & \multicolumn{2}{|c|}{$\begin{array}{l}\text { School enrolment rates } \\
\qquad(15-24)\end{array}$} \\
\hline 2006 & 1996-2006 & 2005 & $\begin{array}{l}1996- \\
2005^{a}\end{array}$ & 2005 & $\begin{array}{l}1996- \\
2005^{b}\end{array}$ & 2005 & $\begin{array}{l}1996- \\
2005^{c}\end{array}$ & 2005 & $\begin{array}{l}1995- \\
2005^{d}\end{array}$ \\
\hline$\%$ & $\begin{array}{l}\text { Percentage } \\
\text { change }\end{array}$ & $\%$ & $\begin{array}{c}\text { Percentage } \\
\text { change }\end{array}$ & $\%$ & $\begin{array}{l}\text { Percentage } \\
\text { change }\end{array}$ & $\%$ & $\begin{array}{l}\text { Percentage } \\
\text { change }\end{array}$ & $\%$ & $\begin{array}{c}\text { Percentage } \\
\text { change }\end{array}$ \\
\hline 10.9 & -7.9 & 9.6 & -2.5 & 58.2 & -8.9 & 5.1 & -0.8 & 26.2 & -1.2 \\
\hline 15.8 & -2.4 & 9.7 & .. & 44.7 & .. & 4.6 & .. & 38.0 & .. \\
\hline 32.3 & -5.9 & 12.4 & -1.3 & 47.4 & -4.7 & 4.4 & -1.5 & 59.5 & -0.4 \\
\hline 2.6 & -4.5 & 9.8 & -3.1 & 39.5 & -3.4 & 3.6 & -1.4 & 36.5 & -1.7 \\
\hline 38.4 & 18.8 & 11.2 & -0.9 & 27.3 & 1.6 & 2.2 & -1.0 & 61.5 & .. \\
\hline 0.9 & -9.6 & 6.2 & -0.7 & 62.0 & .. & 3.5 & 2.7 & 32.0 & 5.3 \\
\hline 5.5 & -5.2 & 9.3 & .. & 41.4 & .. & 3.6 & .. & 56.0 & .. \\
\hline 26.6 & 6.5 & 11.3 & 1.2 & 48.7 & .. & 4.3 & 1.6 & 60.5 & -6.2 \\
\hline 36.7 & 9.1 & 11.6 & 0.0 & 52.3 & 7.7 & 3.6 & 0.3 & 47.4 & .. \\
\hline 47.7 & -5.8 & 15.4 & -3.1 & 37.8 & -4.1 & 5.7 & -0.1 & 59.3 & 2.9 \\
\hline 37.5 & -5.3 & 12.9 & -8.0 & 50.9 & 3.8 & 5.2 & -2.0 & 64.9 & 10.5 \\
\hline 1.5 & -3.9 & 6.4 & -0.4 & 73.5 & .. & 2.9 & 1.0 & 38.0 & 6.6 \\
\hline 25.3 & -21.7 & 8.6 & 0.6 & 48.1 & -11.5 & 3.0 & -0.8 & 45.1 &.. \\
\hline 50.5 & -13.7 & 18.0 & -5.5 & 54.9 & -2.8 & 8.6 & -3.5 & 56.6 & 5.0 \\
\hline 20.4 & 9.9 & 8.8 & 1.2 & 74.6 & 55.5 & .. &.. & 46.2 & 0.9 \\
\hline 0.4 & -1.9 & .. & .. & .. & .. & .. & .. & .. &.. \\
\hline 14.0 & -19.3 & 5.7 & -3.3 & 56.9 & .. & 1.9 & -2.3 & 69.4 & 16.2 \\
\hline 1.9 & 0.7 & 21.8 & -3.9 & 91.3 & 1.5 & 16.5 & -4.3 & 33.0 & -25.4 \\
\hline 21.1 & -13.8 & 6.5 & 1.4 & 59.2 & -5.7 & 2.8 & 2.8 & 31.7 & -1.9 \\
\hline 2.8 & -9.1 & 12.4 &.. & 55.0 & .. & 5.3 & .. & 30.9 &.. \\
\hline 4.3 & -0.1 & 5.9 & -0.9 & 66.5 & 3.5 & 2.1 & 1.5 & 46.5 & -5.4 \\
\hline 37.2 & 8.2 & 12.2 & -8.3 & 62.2 & 4.8 & 1.7 & .. & 69.6 & 14.6 \\
\hline 34.5 & -6.3 & 11.6 & 0.4 & 78.7 & 0.9 & 7.8 & 1.2 & 52.5 & -0.7 \\
\hline 57.6 & 19.8 & 16.1 & -3.9 & 28.8 & 2.8 & 3.4 & -2.5 & 58.4 & 23.6 \\
\hline
\end{tabular}




\begin{tabular}{|c|c|c|c|c|c|c|c|c|c|c|}
\hline Spain & 17.9 & -28.9 & 12.3 & -5.6 & 70.4 & 1.4 & 7.5 & -2.0 & 52.5 & -4.4 \\
\hline Sweden & 4.0 & -9.4 & 8.6 & -2.9 & 28.3 & 2.2 & 1.6 & -1.4 & 57.1 & 6.7 \\
\hline Switzerland & .. &.. & 9.1 & -1.8 & 57.6 & 2.1 & 6.3 & -1.2 & 28.9 & 3.2 \\
\hline Turkey & 32.9 & -10.2 & 42.2 & 8.5 & 53.7 & -10.8 & 16.2 & -3.7 & 26.5 & 2.7 \\
\hline United Kingdom & 14.5 & -10.6 & 13.0 & .. & 55.9 & -0.7 & 5.7 & .. & 35.4 & .. \\
\hline United States & 6.3 & 1.0 & 10.8 & -1.4 & 35.0 & 0.4 & 2.9 & -1.3 & 39.6 & 4.2 \\
\hline EU15 & 27.0 & -13.2 & 11.5 & -0.6 & 58.1 & 1.3 & 5.3 & -0.5 & 48.9 & 0.5 \\
\hline OECD & 19.6 & -5.2 & 15.6 & -0.3 & 57.3 & -0.2 & 7.0 & -1.8 & 42.2 & 2.6 \\
\hline
\end{tabular}

a) 1997 for the Netherlands; 1998 for Italy; 1999 for Germany and Ireland; and 2004 for Mexico.

b) 1997 for Australia, Japan and the Netherlands; 1998 for Italy; 1999 for Germany, Iceland, Ireland and Luxembourg; 2000 for the United Kingdom; and 2004 for Mexico.

c) 1997 for Australia; 1998 for Italy; 1999 for Germany and Ireland; and 2004 for Mexico.

d) 1997 for the Netherlands; 1998 for Japan; 1999 for Greece and Italy; 2000 for the United Kingdom; and 2004 for Mexico.

Source: OECD Labour Force Statistics and Education databases. 
Appendix Table D1. Youth unemployment indicators (most recent available)

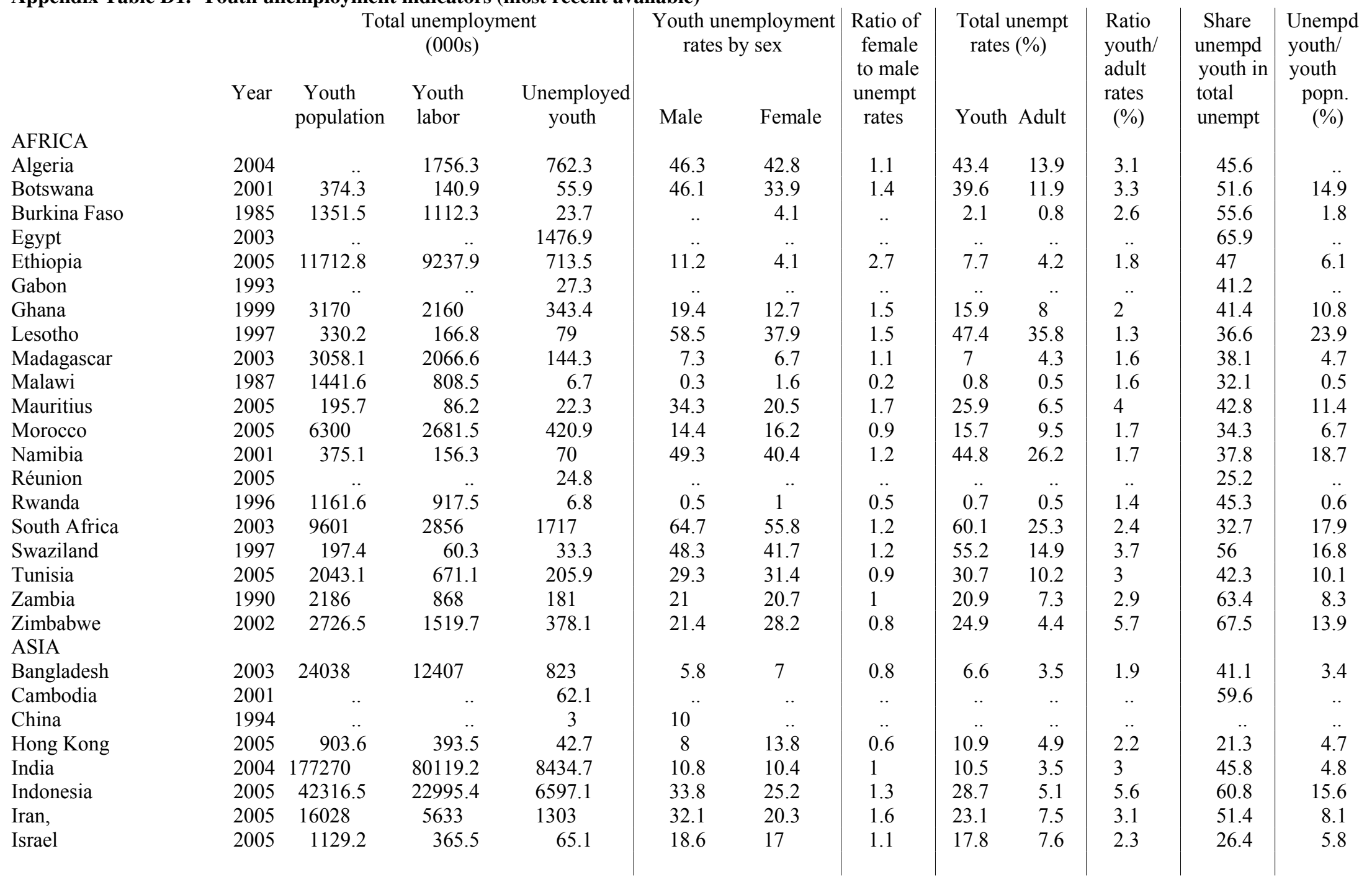




\begin{tabular}{|c|c|c|c|c|c|c|c|c|c|c|c|c|}
\hline & \multicolumn{4}{|c|}{$\begin{array}{l}\text { Total unemployment } \\
\qquad(000 \mathrm{~s})\end{array}$} & \multicolumn{2}{|c|}{$\begin{array}{l}\text { Youth unemployment } \\
\text { rates by sex }\end{array}$} & \multirow{2}{*}{$\begin{array}{c}\text { Ratio of } \\
\text { female } \\
\text { to male } \\
\text { unempt } \\
\text { rates }\end{array}$} & \multicolumn{2}{|c|}{$\begin{array}{l}\text { Total unempt } \\
\text { rates }(\%)\end{array}$} & \multirow{2}{*}{$\begin{array}{l}\text { Ratio } \\
\text { youth } \\
\text { adult } \\
\text { rates } \\
(\%)\end{array}$} & \multirow{2}{*}{$\begin{array}{l}\text { Share } \\
\text { unempd } \\
\text { youth in } \\
\text { total } \\
\text { unempt }\end{array}$} & \multirow{2}{*}{$\begin{array}{l}\text { Unempd } \\
\text { youth/ } \\
\text { youth } \\
\text { popn. } \\
(\%)\end{array}$} \\
\hline & Year & $\begin{array}{l}\text { Youth } \\
\text { population }\end{array}$ & $\begin{array}{l}\text { Youth } \\
\text { labor }\end{array}$ & $\begin{array}{l}\text { Unemployed } \\
\text { youth }\end{array}$ & Male & Female & & Youth & Adult & & & \\
\hline Japan & 2005 & 14210 & 6340 & 550 & 7.4 & 9.9 & 0.7 & 8.7 & 4 & 2.2 & 18.8 & 3.9 \\
\hline Kazakhstan & 2004 & 2712.7 & 1342.5 & 191.6 & 15.7 & 13.1 & 1.2 & 14.3 & 7.2 & 2 & 29.1 & 7.1 \\
\hline Korea, Republic of & 2005 & 6113.1 & 2033.7 & 207.7 & 9 & 12.2 & 0.7 & 10.2 & 3.1 & 3.3 & 23.4 & 3.4 \\
\hline Kyrgyzstan & 2004 & 1048.6 & 476.3 & 72.6 & 17.8 & 13.5 & 1.3 & 15.2 & 6.7 & 2.3 & 39.1 & 6.9 \\
\hline Lao PDR & 1995 & 819.8 & 607.8 & 30.5 & 3.9 & 6.4 & 0.6 & 5 & 0.9 & 5.6 & 56.8 & 3.7 \\
\hline Macau & 2005 & 84.7 & 29.3 & 2.4 & 5.8 & 10.8 & 0.5 & 8.2 & 3.5 & 2.3 & 23.5 & 2.8 \\
\hline Malaysia & 2003 &.. & & 240.6 & .. &.. & .. &.. &.. & 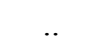 & 65.1 & 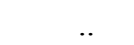 \\
\hline Maldives & 2000 & 56.8 & 22.2 & 1 & 5.1 & 4 & 1.3 & 4.4 & 1.1 & 4 & 57.4 & 1.7 \\
\hline Mongolia & 2003 & 456.8 & 199.3 & 39.9 & 20.7 & 19.5 & 1.1 & 20 & 12.7 & 1.6 & 28 & 8.7 \\
\hline Nepal & 1999 & 3456 & 2818 & 84 & 2.2 & 4 & 0.6 & 3 & 1.4 & 2.1 & 47.2 & 2.4 \\
\hline Pakistan & 2005 & & & 1 & 557 & .. &.. & .. &.. & .. &.. & 48 \\
\hline Papua New Guinea & 2000 & 1029.3 & 609.3 & 32.1 & .. &.. & .. & 5.3 & 2.1 & 2.5 & 48.7 & 3.1 \\
\hline Philippines & 2005 & 16430 & 7787 & 1280 & 18.9 & 14.9 & 1.3 & 16.4 & 4.8 & 3.4 & 48.9 & 7.8 \\
\hline Qatar & 2001 & .. &.. & 5.7 &.. &.. &.. &.. &.. &.. & 45.2 &.. \\
\hline Saudi Arabia & 2002 & .. & .. & 192.8 & .. & .. & .. & .. &.. & .. & 58.7 & .. \\
\hline Singapore & 2005 & .. & 299.8 & 15.6 & 6.3 & 4.1 & 1.5 & 5.2 & 4.1 & 1.3 & 15.5 & .. \\
\hline Sri Lanka & 2005 & 3641.2 & 1521 & 398.3 & 37.1 & 20.1 & 1.8 & 26.2 & 3.3 & 7.9 & 64.3 & 10.9 \\
\hline Syria & 2002 & 3640 & 1895 & 498.8 & 38.9 & 21.4 & 1.8 & 26.3 & 3.9 & 6.7 & 78.2 & 13.7 \\
\hline Taiwan & 2000 & & & 94 &.. &.. & .. &.. & .. & .. & 32.1 & .. \\
\hline Thailand & 2005 & 10577.7 & 5462.1 & 260 & 4.6 & 4.9 & 0.9 & 4.8 & 0.8 & 6 & 52.4 & 2.5 \\
\hline Turkey & 2005 & 12175 & 4710 & 910 & 19.3 & 19.3 & 1 & 19.3 & 8.1 & 2.4 & 36.1 & 7.5 \\
\hline UAE & 2000 & & & 19.3 &.. & & &.. & & & 47 &.. \\
\hline Viet Nam & 2004 & 15523.7 & 9276.3 & 428.3 & 4.9 & 4.4 & 1.1 & 4.6 & 1.5 & 3.1 & 46.2 & 2.8 \\
\hline West Bank/Gaza & 2004 & 701.7 & 179.3 & 71.3 & 44.9 & 38.9 & 1.2 & 39.8 & 23 & 1.7 & 33.7 & 10.2 \\
\hline $\begin{array}{l}\text { Yemen } \\
\text { EUROPE }\end{array}$ & 1999 &.. &.. & 227.1 &.. &.. &.. &.. &.. &.. & 48.4 &.. \\
\hline Albania & 2001 & 527.4 & 315.3 & 111.8 & 27.1 & 41.6 & 0.7 & 35.5 & 18.8 & 1.9 & 36.6 & 21.2 \\
\hline Austria & 2005 & 983.3 & 581.7 & 60.1 & 9.9 & 10.7 & 0.9 & 10.3 & 4.3 & 2.4 & 28.9 & 6.1 \\
\hline Belgium & 2005 & 1263.6 & 419 & 83.3 & 19.1 & 20.6 & 0.9 & 19.9 & 6.9 & 2.9 & 22.5 & 6.6 \\
\hline Bulgaria & 2005 & 1048.5 & 292 & 65.2 & 21.1 & 23.3 & 0.9 & 22.3 & 8.9 & 2.5 & 19.5 & 6.2 \\
\hline Croatia & 2005 &.. & 205.7 & 66.9 & 35.5 & 30.4 & 1.2 & 32.5 & 10.2 & 3.2 & 29.2 &.. \\
\hline Cyprus & 2005 & 93.2 & 39.7 & 5.5 & 14.6 & 13.7 & 1.1 & 13.9 & 4.2 & 3.3 & 28.2 & 5.9 \\
\hline
\end{tabular}




\begin{tabular}{|c|c|c|c|c|c|c|c|c|c|c|c|c|}
\hline \multirow[b]{3}{*}{ Czech Republic } & \multirow[b]{2}{*}{ Year } & \multicolumn{3}{|c|}{$\begin{array}{l}\text { Total unemployment } \\
\text { (000s) }\end{array}$} & \multicolumn{2}{|c|}{$\begin{array}{l}\text { Youth unemployment } \\
\text { rates by sex }\end{array}$} & \multirow{2}{*}{$\begin{array}{c}\text { Ratio of } \\
\text { female } \\
\text { to male } \\
\text { unempt } \\
\text { rates }\end{array}$} & \multicolumn{2}{|c|}{$\begin{array}{l}\text { Total unempt } \\
\text { rates }(\%)\end{array}$} & \multirow{2}{*}{$\begin{array}{l}\text { Ratio } \\
\text { youth } \\
\text { adult } \\
\text { rates } \\
(\%)\end{array}$} & \multirow{2}{*}{$\begin{array}{l}\text { Share } \\
\text { unempd } \\
\text { youth in } \\
\text { total } \\
\text { unempt }\end{array}$} & \multirow{2}{*}{$\begin{array}{l}\text { Unempd } \\
\text { youth/ } \\
\text { youth } \\
\text { popn. } \\
(\%)\end{array}$} \\
\hline & & $\begin{array}{l}\text { Youth } \\
\text { population }\end{array}$ & $\begin{array}{l}\text { Youth } \\
\text { labor }\end{array}$ & $\begin{array}{l}\text { Unemployed } \\
\text { youth }\end{array}$ & Male & Female & & Youth & Adult & & & \\
\hline & 2005 & 1357 & 459.6 & 88.5 & 19.1 & 19.4 & 1.0 & 19.3 & 6.8 & 2.8 & 21.6 & 6.5 \\
\hline Denmark & 2005 & 591.1 & 397.5 & 31.2 & 9.8 & 6.1 & 1.6 & 7.9 & 4.3 & 1.8 & 22.6 & 5.3 \\
\hline Estonia & 2005 & 207.8 & 70.8 & 11.2 & 15.1 & 16.4 & 0.9 & 15.8 & 6.9 & 2.3 & 21.5 & 5.4 \\
\hline Finland & 2005 & 653 & 321 & 64 & 19.3 & 20.6 & 0.9 & 19.9 & 6.8 & 2.9 & 29.0 & 9.8 \\
\hline France & 2005 & 7833.9 & 2636.6 & 600.8 & 24.6 & 21.4 & 1.1 & 22.8 & 8.5 & 2.7 & 22.1 & 7.7 \\
\hline Georgia & 2005 & 578.3 & 195.5 & 55.3 & 30.6 & 26.8 & 1.1 & 28.3 & 12.3 & 2.3 & 19.8 & 9.6 \\
\hline Germany & 2005 & 9783 & 4911 & 746 & 14.0 & 16.1 & 0.9 & 15.2 & 10.6 & 1.4 & 16.3 & 7.6 \\
\hline Greece & 2005 & 1232.1 & 417.1 & 105.4 & 34.7 & 17.5 & 2.0 & 25.3 & 8.2 & 3.1 & 22.6 & 8.6 \\
\hline Hungary & 2005 & 1271 & 344.2 & 66.9 & 19.1 & 19.7 & 1.0 & 19.4 & 6.1 & 3.2 & 22.0 & 5.3 \\
\hline Iceland & 2005 & 36.7 & 28.3 & 2.0 & 6.0 & 8.5 & 0.7 & 7.2 & 1.6 & 4.5 & 47.7 & 5.6 \\
\hline Ireland & 2005 & 637.3 & 321.8 & 26.6 & 7.3 & 9.1 & 0.8 & 8.3 & 3.5 & 2.4 & 31.1 & 4.2 \\
\hline Italy & 2005 & 6103 & 2044 & 490 & 27.4 & 21.5 & 1.3 & 24.0 & 6.2 & 3.9 & 25.9 & 8.0 \\
\hline Latvia & 2005 & 359.6 & 134.6 & 17.5 & 14.2 & 11.9 & 1.2 & 13.0 & 8.2 & 1.6 & 17.7 & 4.9 \\
\hline Lithuania & 2005 & 526.1 & 131.6 & 20.7 & 15.3 & 15.9 & 1.0 & 15.7 & 7.6 & 2.1 & 15.6 & 3.9 \\
\hline Luxembourg & 2005 & 51.9 & 15.0 & 2.1 & 16.2 & 11.7 & 1.4 & 13.7 & 3.8 & 3.6 & 22.6 & 4.0 \\
\hline Malta & 2004 & 61.0 & 33.8 & 5.6 & 17.4 & 15.8 & 1.1 & 16.6 & 4.5 & 3.7 & 48.6 & 9.2 \\
\hline Netherlands & 2005 & 1938 & 1326 & 127 & 9.7 & 9.5 & 1.0 & 9.6 & 4.4 & 2.2 & 29.5 & 6.6 \\
\hline Norway & 2005 & 508.4 & 306 & 36.8 & 11.5 & 12.5 & 0.9 & 12.0 & 3.5 & 3.4 & 33.3 & 7.2 \\
\hline Poland & 2005 & 5594.4 & 1876.5 & 708.8 & 39.2 & 36.7 & 1.1 & 37.8 & 15.3 & 2.5 & 23.3 & 12.7 \\
\hline Portugal & 2005 & 1312.9 & 564.2 & 90.7 & 19.1 & 13.7 & 1.4 & 16.1 & 6.7 & 2.4 & 21.5 & 6.9 \\
\hline Moldova & 2005 & 701.1 & 152.2 & 28.6 & 18.3 & 19.1 & 1.0 & 18.8 & 5.9 & 3.2 & 27.6 & 4.1 \\
\hline Romania & 2005 & 3354.3 & 1068.7 & 210.3 & 18.4 & 20.5 & 0.9 & 19.7 & 5.6 & 3.5 & 29.9 & 6.3 \\
\hline Russia & 1999 & 22162.4 & 9284 & 2296 & 25.9 & 23.9 & 1.1 & 24.7 & 11.6 & 2.1 & 24.6 & 10.4 \\
\hline Slovakia & 2005 & 875.3 & 319.6 & 95.5 & 28.7 & 30.8 & 0.9 & 29.9 & 14.3 & 2.1 & 22.3 & 10.9 \\
\hline Slovenia & 2005 & 265 & 97 & 13 & 12.2 & 10.7 & 1.1 & 13.4 & 4.9 & 2.7 & 22.4 & 4.9 \\
\hline Spain & 2005 & 4784.8 & 2494.7 & 490.5 & 23.5 & 16.7 & 1.4 & 19.7 & 7.7 & 2.6 & 25.6 & 10.3 \\
\hline Sweden & 2005 & 983 & 538 & 120 & 21.6 & 23.0 & 0.9 & 22.3 & 5.8 & 3.8 & 33.3 & 12.2 \\
\hline Switzerland & 2005 & 875.1 & 575.3 & 50.8 & 9.2 & 8.5 & 1.1 & 8.8 & 3.7 & 2.4 & 27.5 & 5.8 \\
\hline Macedonia & 2005 & 326.5 & 107.3 & 67.2 & 62.1 & 63.0 & 1.0 & 62.6 & 33.7 & 1.9 & 20.7 & 20.6 \\
\hline Ukraine & 2005 & 7491.7 & 3011.7 & 448.3 & 14.4 & 15.2 & 0.9 & 14.9 & 6.0 & 2.5 & 28.0 & 6.0 \\
\hline United Kingdom & 2005 & 6726 & 4430 & 521 & 10.0 & 13.4 & 0.7 & 11.8 & 3.3 & 3.6 & 38.6 & 7.7 \\
\hline
\end{tabular}




\begin{tabular}{|c|c|c|c|c|c|c|c|c|c|c|c|c|}
\hline \multirow[b]{2}{*}{ LATIN AMERICA AND } & \multirow[b]{2}{*}{ Year } & \multicolumn{3}{|c|}{$\begin{array}{l}\text { Total unemployment } \\
\qquad(000 \mathrm{~s})\end{array}$} & \multicolumn{2}{|c|}{$\begin{array}{l}\text { Youth unemployment } \\
\text { rates by sex }\end{array}$} & \multirow{2}{*}{$\begin{array}{l}\text { Ratio of } \\
\text { female } \\
\text { to male } \\
\text { unempt } \\
\text { rates }\end{array}$} & \multicolumn{2}{|c|}{$\begin{array}{l}\text { Total unempt } \\
\text { rates }(\%)\end{array}$} & \multirow{2}{*}{$\begin{array}{l}\text { Ratio } \\
\text { youth } \\
\text { adult } \\
\text { rates } \\
(\%)\end{array}$} & \multirow{2}{*}{$\begin{array}{l}\text { Share } \\
\text { unempd } \\
\text { youth in } \\
\text { total } \\
\text { unempt }\end{array}$} & \multirow{2}{*}{$\begin{array}{l}\text { Unempd } \\
\text { youth/ } \\
\text { youth } \\
\text { popn. } \\
(\%)\end{array}$} \\
\hline & & $\begin{array}{l}\text { Youth } \\
\text { population } \\
\text { CARIBBEAN }\end{array}$ & $\begin{array}{l}\text { Youth } \\
\text { labor }\end{array}$ & $\begin{array}{l}\text { Unemployed } \\
\text { youth }\end{array}$ & Male & Female & & Youth & Adult & & & \\
\hline Anguilla & 2001 & 1.8 & 1.1 & 0.1 & 17.8 & 10.0 & 1.8 & 13.5 & 5.2 & 2.6 & 36.8 & 8.3 \\
\hline Antigua \& Barbuda & 1991 &.. & 6.4 & 0.8 &.. &.. & .. & 13.1 & 4.1 & 3.2 & 47.5 &.. \\
\hline Argentina & 2005 & 4083.3 & 1859.9 & 450.1 & 28 & 21.6 & 1.3 & 24.2 & 7.7 & 3.1 & 39.6 & 11.0 \\
\hline Aruba & 1997 & .. & 5.0 & 1.0 & 24.5 & 16.7 & 1.5 & 20.4 & 5.8 & 3.5 & 31.1 &.. \\
\hline Bahamas & 2005 & .. & 30.7 & 6.2 & 24.1 & 16.9 & 1.4 & 20.2 & 8.1 & 2.5 & 34.3 & .. \\
\hline Barbados & 2003 & 36.1 & 20.6 & 5.4 & 28.7 & 24.1 & 1.2 & 26.2 & 8.5 & 3.1 & 33.8 & 15.0 \\
\hline Belize & 2005 & .. & 29.2 & 5.7 & 28.9 & 13.8 & 2.1 & 19.5 & 8 & 2.4 & 46.8 &.. \\
\hline Bolivia & 2002 & .. & 911.3 & 84 & 11.8 & 7.3 & 1.6 & 9.2 & 4.1 & 2.2 & 42.1 & .. \\
\hline Brazil & 2004 & 34814.4 & 22254.1 & 4021.8 & 23.3 & 14.2 & 1.6 & 18.1 & 5.9 & 3.1 & 49.8 & 11.6 \\
\hline British Virgin Islands & 1991 & .. & 1.7 & 0.1 & 7.2 & 7.6 & 0.9 & 7.5 & 2.7 & 2.8 & 40.6 & .. \\
\hline Cayman Islands & 1997 & .. & 2.7 & 0.3 &.. & &.. & 9.3 & 3.4 & 2.7 & 28.1 & .. \\
\hline Chile & 2005 & 2639.6 & 819.8 & 141.9 & 21.0 & 15.2 & 1.4 & 17.3 & 5.4 & 3.2 & 32.2 & 5.4 \\
\hline Colombia & 2005 & 10469.6 & 4447.8 & 660.9 & 19.4 & 11.6 & 1.7 & 14.9 & 8 & 1.9 & 34 & 6.3 \\
\hline Costa Rica & 2005 & 856.7 & 419.3 & 63 & 21.5 & 11.3 & 1.9 & 15 & 4.2 & 3.6 & 50.3 & 7.4 \\
\hline Dominica & 2001 & 11.0 & 4.7 & 1.2 & 26.7 & 25.5 & 1 & 26 & 7.7 & 3.4 & 40 & 11.1 \\
\hline Dominican Republic & 2004 & .. &.. & 301.8 &.. & &.. & $\cdot$. &.. &.. & 42.5 &.. \\
\hline Ecuador & 2005 & 1731.5 & 863.9 & 134.1 & 20.6 & 12.2 & 1.7 & 15.5 & 5.7 & 2.7 & 41.7 & 7.7 \\
\hline El Salvador & 2004 & 1333.2 & 626.6 & 72.2 & 9.4 & 12.7 & 0.7 & 11.5 & 5.3 & 2.2 & 40.2 & 5.4 \\
\hline French Guiana & 2005 & .. & .. & 2.9 &.. &.. &.. &.. & .. &.. & 18.5 & .. \\
\hline Grenada & 1998 & 16.0 & 9.7 & 3.0 & 39.4 & 25.4 & 1.6 & 31.5 & 10.2 & 3.1 & 49 & 19.0 \\
\hline Guadeloupe & 2005 & .. & .. & 6.3 &.. &.. &.. &.. &.. & .. & 14.9 &.. \\
\hline Guyana & 2001 & .. & 61 & 12.2 & 24.4 & 17.5 & 1.4 & 20 & 5.8 & 3.4 & 51 & .. \\
\hline Haiti & 1999 & 1553.9 & 496.5 & 89.1 & 21.1 & 15.1 & 1.4 & 17.9 & 5.0 & 3.6 & 42.6 & 5.7 \\
\hline Honduras & 2005 & 1562.3 & 756.9 & 53.2 & 11.2 & 5.2 & 2.2 & 7.0 & 3.0 & 2.3 & 50.2 & 3.4 \\
\hline Jamaica & 2005 &.. &.. & 51.9 &.. &.. &.. &.. &.. &.. & 39.8 &.. \\
\hline Martinique & 2005 &.. &.. & 5.5 &.. &.. &.. & .. & .. & .. & 15.7 & .. \\
\hline Mexico & 2005 & 19553.7 & 9145.5 & 600.5 & 7.4 & 6.1 & 1.2 & 6.6 & 2.7 & 2.4 & 40.4 & 3.1 \\
\hline Netherlands Antilles & 2000 & 16.8 & 5.7 & 1.5 & 29.7 & 25.4 & 1.2 & 26.9 & 12.7 & 2.1 & 18 & 9.1 \\
\hline Nicaragua & 2003 & 1165.1 & 589.6 & 73.8 & 15.8 & 10.8 & 1.5 & 12.5 & 6.1 & 2.0 & 45.7 & 6.3 \\
\hline Panama & 2005 & 523 & 255.9 & 57.6 & 29.6 & 18.5 & 1.6 & 22.5 & 7.4 & 3.0 & 42.1 & 11.0 \\
\hline Paraguay & 2003 & .. & 664 & 101.3 & 20.5 & 12.1 & 1.7 & 15.3 & 5.2 & 2.9 & 52.3 &.. \\
\hline
\end{tabular}




\begin{tabular}{|c|c|c|c|c|c|c|c|c|c|c|c|c|}
\hline & \multicolumn{4}{|c|}{$\begin{array}{l}\text { Total unemployment } \\
\qquad(000 \mathrm{~s})\end{array}$} & \multicolumn{2}{|c|}{$\begin{array}{l}\text { Youth unemployment } \\
\text { rates by sex }\end{array}$} & \multirow{2}{*}{$\begin{array}{l}\text { Ratio of } \\
\text { female } \\
\text { to male } \\
\text { unempt } \\
\text { rates }\end{array}$} & \multicolumn{2}{|c|}{$\begin{array}{l}\text { Total unempt } \\
\text { rates (\%) }\end{array}$} & \multirow{2}{*}{$\begin{array}{l}\text { Ratio } \\
\text { youth } \\
\text { adult } \\
\text { rates } \\
(\%)\end{array}$} & \multirow{2}{*}{$\begin{array}{l}\text { Share } \\
\text { unempd } \\
\text { youth in } \\
\text { total } \\
\text { unempt }\end{array}$} & \multirow{2}{*}{$\begin{array}{l}\text { Unempd } \\
\text { youth/ } \\
\text { youth } \\
\text { popn. } \\
(\%)\end{array}$} \\
\hline & Year & $\begin{array}{l}\text { Youth } \\
\text { population }\end{array}$ & $\begin{array}{l}\text { Youth } \\
\text { labor }\end{array}$ & $\begin{array}{l}\text { Unemployed } \\
\text { youth }\end{array}$ & Male & Female & & Youth & Adult & & & \\
\hline Peru & 2005 & 1723.6 & 836.3 & 174.5 & 20.7 & 21.0 & 1.0 & 20.9 & 8.8 & 2.4 & 39.9 & 10.1 \\
\hline Puerto Rico & 2005 & 539 & 215 & 50.0 & 20.9 & 24.8 & 0.8 & 23.3 & 9.2 & 2.5 & 31.3 & 9.3 \\
\hline St Helena & 1998 & 0.8 & 0.5 & 0.1 & 30.5 & 32.5 & 0.9 & 25.2 & 16.0 & 1.6 & 28.1 & 16.8 \\
\hline St Lucia & 2003 & .. & 16.2 & 6.5 & 49.2 & 31.8 & 1.5 & 40.0 & 20.5 & 2.0 & 35.6 & 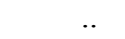 \\
\hline St Vincent & & 1991 & & 12.6 & 4.6 & 43.0 & 32.8 & 1.3 & 36.3 & 12.7 & 2.9 & 55.3 \\
\hline Suriname & 1999 & 47.6 & 12.2 & 4.1 & 58.1 & 24.1 & 2.4 & 33.9 & 10.4 & 3.3 & 35.0 & 8.7 \\
\hline Trinidad \& Tobago & 2005 & .. & .. & 21.7 & .. & &.. & .. &.. & .. & 43.7 & .. \\
\hline Uruguay & 2005 & 457.8 & 219.6 & 64.8 & 34.9 & 25.4 & 1.4 & 29.5 & 8.6 & 3.4 & 41.8 & 14.2 \\
\hline Venezuela & 2003 & 4976.8 & 2691.6 & 752.5 & 34.8 & 23.7 & 1.5 & 28.0 & 13.5 & 2.1 & 37.3 & 15.1 \\
\hline NORTH AMERICA & & & & & & & & & & & & \\
\hline Canada & 2005 & 4280.2 & 2822.7 & 350.2 & 10.6 & 14.2 & 0.7 & 12.4 & 5.7 & 2.2 & 29.9 & 8.2 \\
\hline USA & 2005 & 36674 & 22291 & 2521 & 10.1 & 12.4 & 0.8 & 11.3 & 4.0 & 2.8 & 33.2 & 6.9 \\
\hline OCEANIA & & & & & & & & & & & & \\
\hline Australia & 2005 & 2842.9 & 2025.8 & 219.1 & 10.5 & 11.1 & 0.9 & 10.8 & 3.7 & 2.9 & 40.8 & 7.7 \\
\hline New Zealand & 2005 & 590.9 & 371.2 & 34.9 & 9.8 & 9.1 & 1.1 & 9.4 & 2.5 & 3.8 & 44.0 & 5.9 \\
\hline New Caledonia & 1996 &.. & 29.5 & 9.9 & 38.5 & 29.7 & 1.3 & 33.6 & 19.4 & 1.7 & 66.0 & .. \\
\hline
\end{tabular}

Source: United Nations (2007) Source: International Labour Organization, Key Indicators of the Labour Market, 5th edition (Geneva: 2007).

Notes: Data repositories are mainly LABORSTA, an International Labour Office database on labour statistics; and the Organization for Economic Cooperation and Development (OECD). Two dots (..) indicate that data are not available or are not separately reported. 